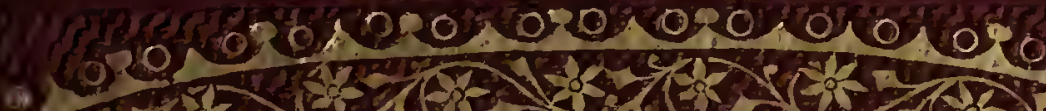

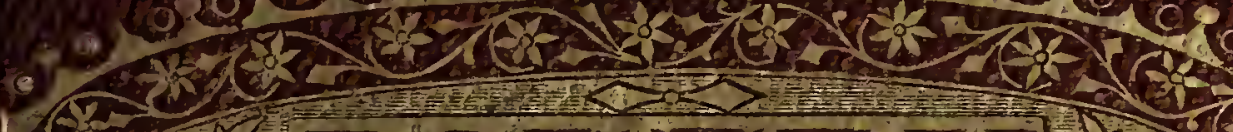

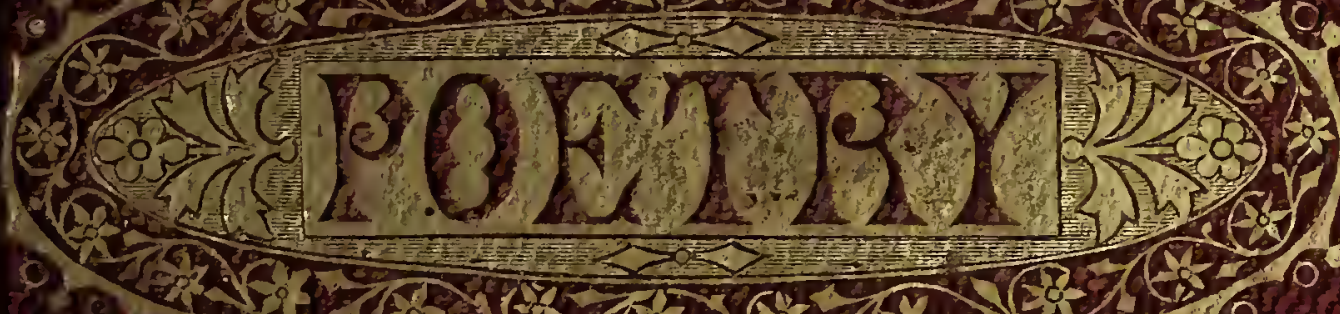

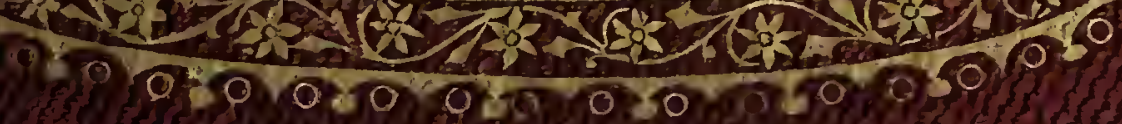

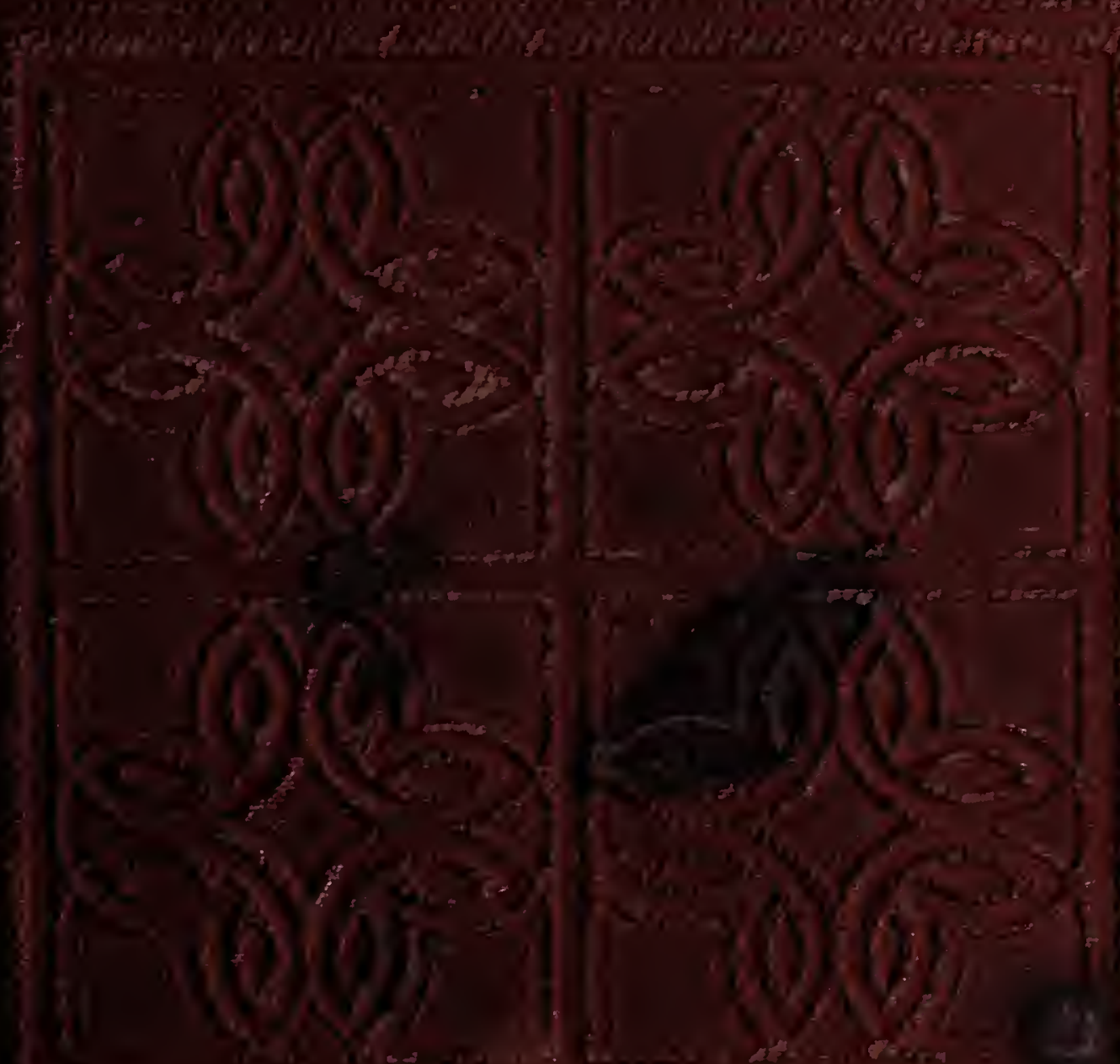




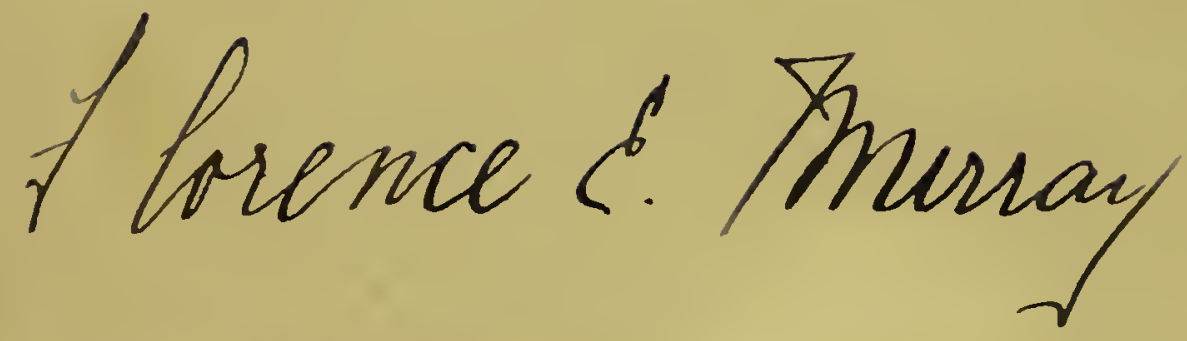

$$
P B 325319
$$

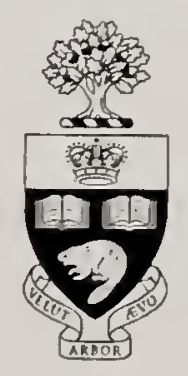

Presented to the

LIBRARIES of the

UNIVERSITY OF TORONTO

by

Larry Pfaff 


Cospenterc

ifs Anwoice Bazosioges ficonen u

Bricsole

given

Ftorence C. Dussay 




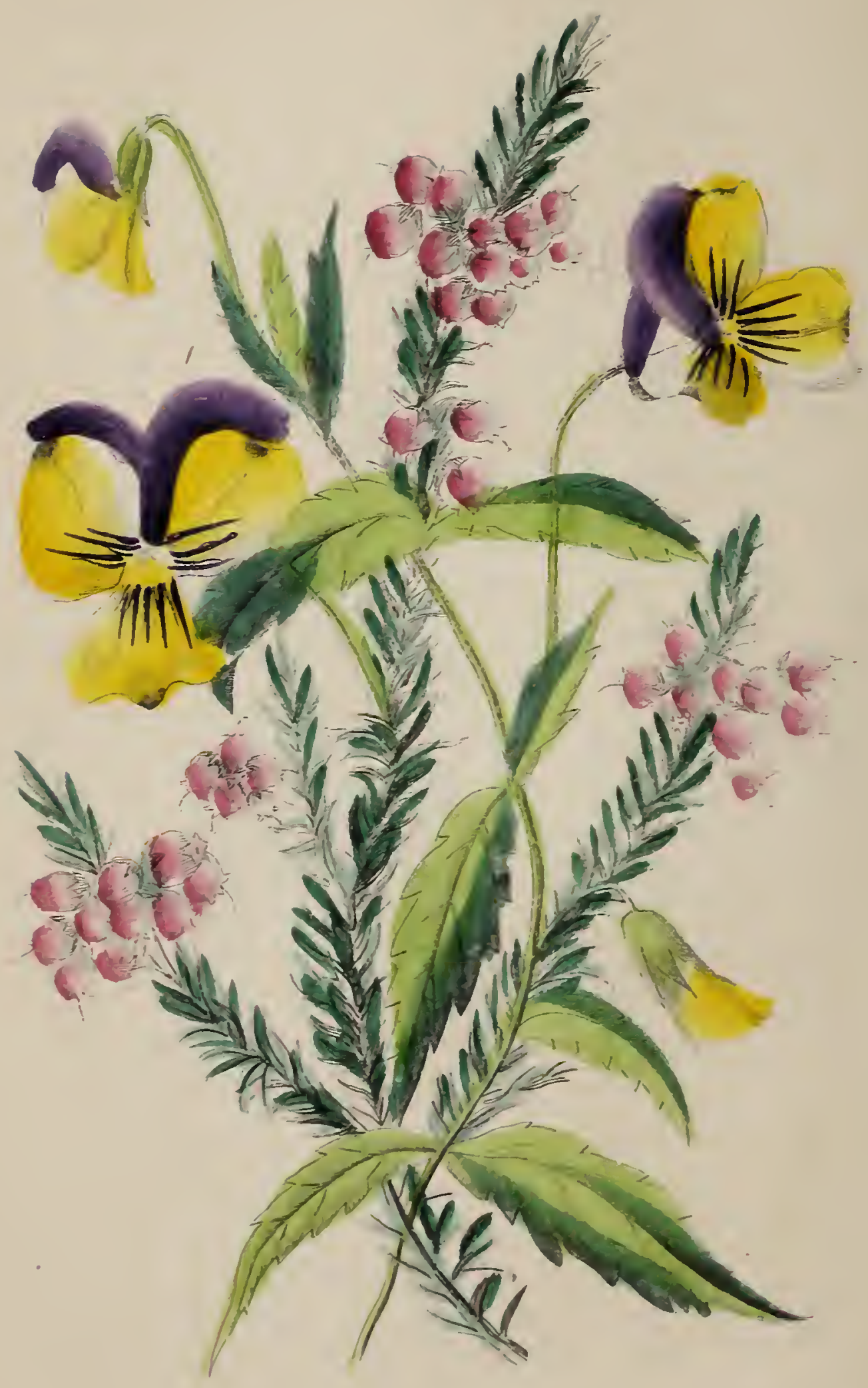




\section{THE}

\section{PUETRY OF FLOWERS}

F L O W E R S O F P O E T R Y

TO WHICF $\triangle R E \triangle D D E D$,

A SIMPLE TREATISE ON BOTANY,

WITH FAMILIAR EXAMPLES,

$\triangle X \mathbb{D} \Delta$

COPIOUS FLORAL DICTIONARI.

2DITED BY

FRANCES S. OSGOOD.

N E W Y R K :

DERBY \& JACKSON, 119 NASSAU STREET. 1860. 



\section{P R E F A C E.}

Most of the prose portions of the following pages, have been adopted from an English work, entitled "The Sentiment of Flowers." The editor has made a few alterations and additions, in order to adapt it to American readers, and has illustrated the whole with poetical sentiments, original and selected

As an apology may be deemed necessary for apparent egotism, in introducing so frequently her own effusions, among those of a far higher order, it seems proper to state, that, where an appropriate quotation did not immediately occur to memory, it appeared the shortest and easiest, if not the wisest way to compose, at the moment, a few lines or verses suitable to the flower and its sentiment. 
$1 \quad$ PREFACE.

The chapter on botany will be found complete within itself, and according to the most approved systemthat of Linnæus. It will serve as an interesting introduction for those who have not had the advantage of the study in their education, and may recall to memory its principles where they have been learned and forgotten.

The editor can pretend to no erudition on the subject. Only Fancy and Feeling have woven a wreath which may yield neither bloom nor sweetness, unless the sunshine of Indulgence, and the kindly dew of Sympathy, be suffered to play on its leaves

F. S. 0 . 


\section{Plate I.-Frontispiece.}

I I. L USTRATION OF FRONTISPIECE.

$$
\text { Rose.-Ivy.-Myrtle. }
$$

To Beauty, Friendship, and Love

$\mathrm{OH}$ ! Beauty! bright rose of the world!

Oh, Love! the soul's myrtle for ever!

Oh, Friendship! fair vine round a breaking heart curled,

Without whose soft bonds it would sever!

For you a rich garland we braid,

Breathing sighs of pure incense above;-

It will bloom in the sun, it will smile in the shade, For Beauty, for Friendship, and Love!

s. \& c. 
I sing of brooks, of blossoms, birds, and bowers, Of April, May, of June and July flowers;

I sing of youth, of love too, and I write How roses first came red, and lilies white:

I write of groves and twilight, and I sing The court of Mab, and of the Fairie King.

HERRICK.

There's wit in every flower, if you can gather it. SHJRELET. 


\section{N T RODUCTION}

OF FLowrrs, so much has been said and sung, that it were impossible to write any thing new. They have been called "the joy of the shrubs which bear them ;" - "the stars of the earth;" and the "alphabet of the angels;" and, indeed, as says Mr. Howitt, "of all the minor creations of God, they seem to be most cornpletely. the effusions of his love of beauty, grace, and joy. Beauty and fragrance are poured abroad over the earth in blossoms of endless varieties, radiant evidences of the boundless benevolence of the Deity. They are made solely to gladden the heart of man, for a light to his eyes, for a living inspiration of grace to his spirit, for a perpetual admiration. And accordingly they seize on our affections the first moment that we behold them. With what eagerness do very infants grasp at flowers! As they become older, they would live for ever among them. They bound about in the flowery meadows like young fawns; they gather all they come near; they collect heaps; they sit among them and sort them, and sing over them and ceress them, till they perish in their grasp.

This sweet May morning

The children are pulling

On every side,

In a thousand valleys far and wide,

Fresh flowers.

WORDSWORTH. 
We see them coming wearily into the towns and villages wila their pin-a-fores full, and with posies half as large as the.aselves. We trace them in shady lanes, in the grass of far-wff fields, by the treasures they have gathered and bave left bet. nd, lured on by others still greater.

$\therefore$ ds they grow up to maturity, they assume, in their eyes, nen characters and beauties. Then they are strewn around thel 1 , the poetry of the earth. They become invested, by a mul itude of associations, with innumerable spells of power ovel the human heart; they are to us memorials of the joys, sorrows, hopes, and triumphs of our forefathers; they are, to all nations, the emblems of youth in its loveliness and purity."

Flowers to the Fair! to you these flowers I bring,

And strive to greet you with an earlier spring;

Flowers sweet and gay, and delicate like you,

Emblems of innocence and beauty too.

With flowers the Graces bind their yellow hair,

And flowery wreaths consenting lorers wear.

Flowers, the sole luxury which Nature knew,

In Eden's pure and guiltless garden grew.

Mrs. Barbduld.

Let Fancy lead us, with her fair imaginings, and it shall te in pleasant paths, and through flowery ways;

Go, cull the golden fruits of truth;

Go, gather fancy's brilliant flowers;

and for a brief space let us wander in an earthly Eden. TWe will rove, hand in hand, with the ever-youthful goddess of ? flowers; and Zephyrus, her beloved, shall waft tributary hon ours from every clime. We will twine fair garlands for man:" a youthful brow; "we will not let a flower of the spring escape us;" but "crown ourselves with roses ere they be withered." We may roam with Tasso through Syrian lands, 
"where soft perfumes diffuse from every flower ;" or the deserts of Arabia, where

The acacia waves her yellow hair;

or shall we choose the Grecian Isles, and join there a bridis train, "where the voung maidens are crowned with fairest flowers? And there on every side are seen a succession of narcissuses, hyacinths, anemones, iris, all hues, violets of all sorts, roses of every kind, and every odoriferous plant." These the ancient Greeks scattered in the porticoes of their temples: with them they adorned their altars, and decorated the statues of their gods; they strewed them in the victor's path; and wore wreaths of flowers in their holy ceremonies.

It was the custom there to bring away

The bride from home at blushing shut of day,

Veiled in a chariot, heralded along

By strewn flowers, torches, and a marriage song.

KEATS.

And at tneir banquets and festivals they crowned themselves with

Garlands of every green, and every scent, Frơm vales deflowered or forest-trees branch-rent, In baskets of bright osiered gold were brought, High as the handles heaped, to suit the thought of every guest, that each as he did please

Might fancy-fit his brows, silk-pillowed at his ease.

KeAts.

If we pass to Italy, we shall find lilies, and violets, the narcissus, and flowers of the sweet smelling anise; with cassia, and other fragrant herbs, the soft hyacinth, and the saffron marigold. And in Spain we may 


\section{rest awhile in the bower,}

O'er which the white-leaved orange flower

Breathes its ambrosial sweets.

Melendez.

Now let us away to the distant lands of Asia, where we shall not find the glorious garden of Eden, nor the far-famed gardens of once mighty Babylon; but there we may repose on beds of roses in Cashmere; and with the Persian maidens weave garlands of the violet, jasmine, or lotus flowers; we may trim the odorous night-blooming nyctanthes, with the drooping mimosa, which seems to do us homage as we approach it; we may cull the rich blossom from the canna, the white arum, the yellow zanthium, and the classic hibiscus; we may rest secure under the bata tree, or recline beneath the dark and gloomy cypresses. Or seeing, should we prefer the plain of various colours, clad with groves and gardens, and watered by flowing rivulets? It is a place belonging to the abodes of heroes. The ground is silky in its appearance, and the air is scented with musky odours; so that you would be led to ask, Is it rose-water which glides between the banks? The stalk of the lily bends under the weight of the flower; and the whole grove is charmed with the fragrance of the rosebud. The pheasant walks gracefully among the flowers; and the dove and the nightingale warble from the branches of the cypress. From the present time to the latest age, may these banks resemble the bowers of Paradise !*

In Hindostan, the god of love is krown as Camdeo. There we may see the fair young child surrounded I , gay laughterloving nymphs. His mother never leaves him - his spouse is Retty, the essence of affection - and his bosom friend is Bes-

- Sir William Jones. 
sent, or Spring. The plains of Agra are his favourite resort. His bow is of sugar-cane, twined with flowers; his string is of bees; his five arrows are each pointed with an Indian flower. The Hindoo nymphs chant the following hvmn to the Indian cupid :-

God of the flowery shafts and flowery bow,

Delight of all above and all below!

Thy loved companion, constant from his birth,

Is ycleped Bessent, gay spring on earth,

Weaves thy green robes and flaunting bowers,

And from thy cloud draws balmy showers,

He with fresh arrows fills thy quiver,

(Sweet the gift, and sweet the giver,)

And bids the many-plumed warbling throng

Burst the fresh blossoms with their song:

"He bends the luscious cane, and twists the string

With bees - how sweet, but ah ! how keen their sting,

He with five fowerets tips thy ruthless darts,

Which? through five senses pierce enraptured hearts."

Translation by Sir William JoNF .

But we will leave this dangerous land, and wander th ough the ever-blooming vales of Japan. Let us deck ourselves with her gorgeous lilies - her Japonicas - her flowers so beautiful that even the females are named from them. Wherever we roam, we shall find that nature strews the earth with flowers.

We proceed to take a brief survey of the habits of flowers. Many varieties open their flowers in the morning, and close them in the evening; yet all do not open or close at the same hour. Plants of the same species are pretty regular to an hour in equal temperatures: hence the daily opening and shutting of the flowers has been called Horologium Floræ.

[t has been very truly observed that flowers were the first aythings of Linnæus: whose motto was,

Tantus amor florum. 
This devoted lover of flowers carefully noticed the sensibility of plants, and composed a horologe of flowers. The list is given in his "Philosophia Botanıca," which, however, is only valuable to us in giving the names of plants which open and close at stated periods, as the time given is for the meridian of Upsal. For the use of our friends we have given a list of twenty-four, extracted from that magnificent and useful work, the Encyclopædia of Gardening, by J. C. Loudon, Esq., and by ubservation of the following plants, also, the ingenious reader may be enabled to add to the number. Many species of convolvulus and companula, the marvel of Peru, or belle-de-nuit, broom, tulips, cress, hibiscus, yellow lily, white water-lily, and dianthus.

See hieracium's various tribe, of pluniy seed and radiate flowers, The blooms of time their course describe, And wake and sleep appointed hours.

Broad o'er its imbricated cap,

The goat's-beard spreads its golden rays,

But shuts its cautious petals up,

Retreating from the noontide blaze.

Pale as a pensive cloistered nun, The Bethlehem-star her face unveils, When o'er the mountain peers the sun, But shades it from the resper gales.

Among the loose and arid sands

The humble arenaria creeps;

Slowly the purple star expands,

But soon within its calyx sleeps.

And those small bells so lightly rayed

With young Aurora's rosy hue, 


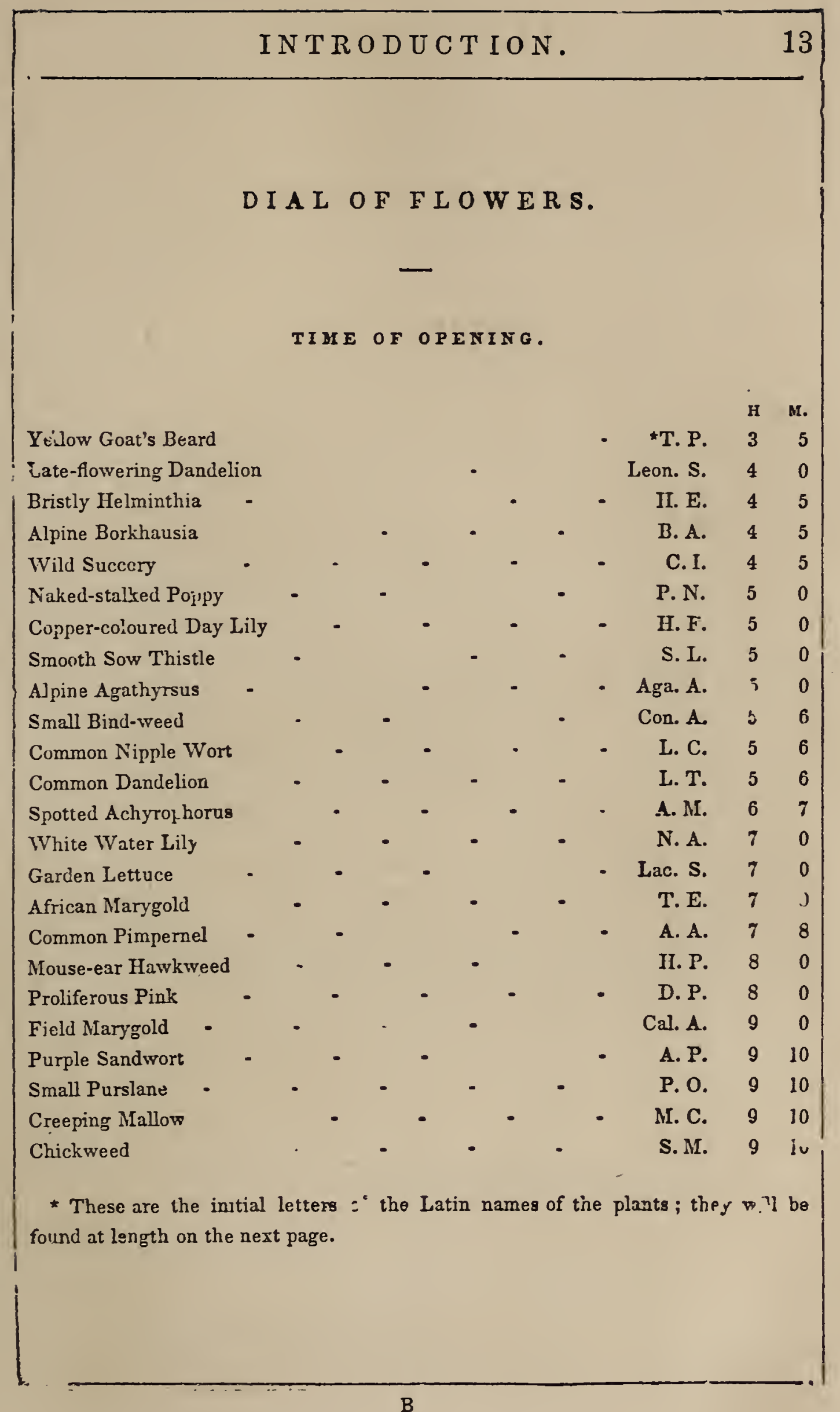


DI A O F F L W E R .

TIME OF CLOSING.

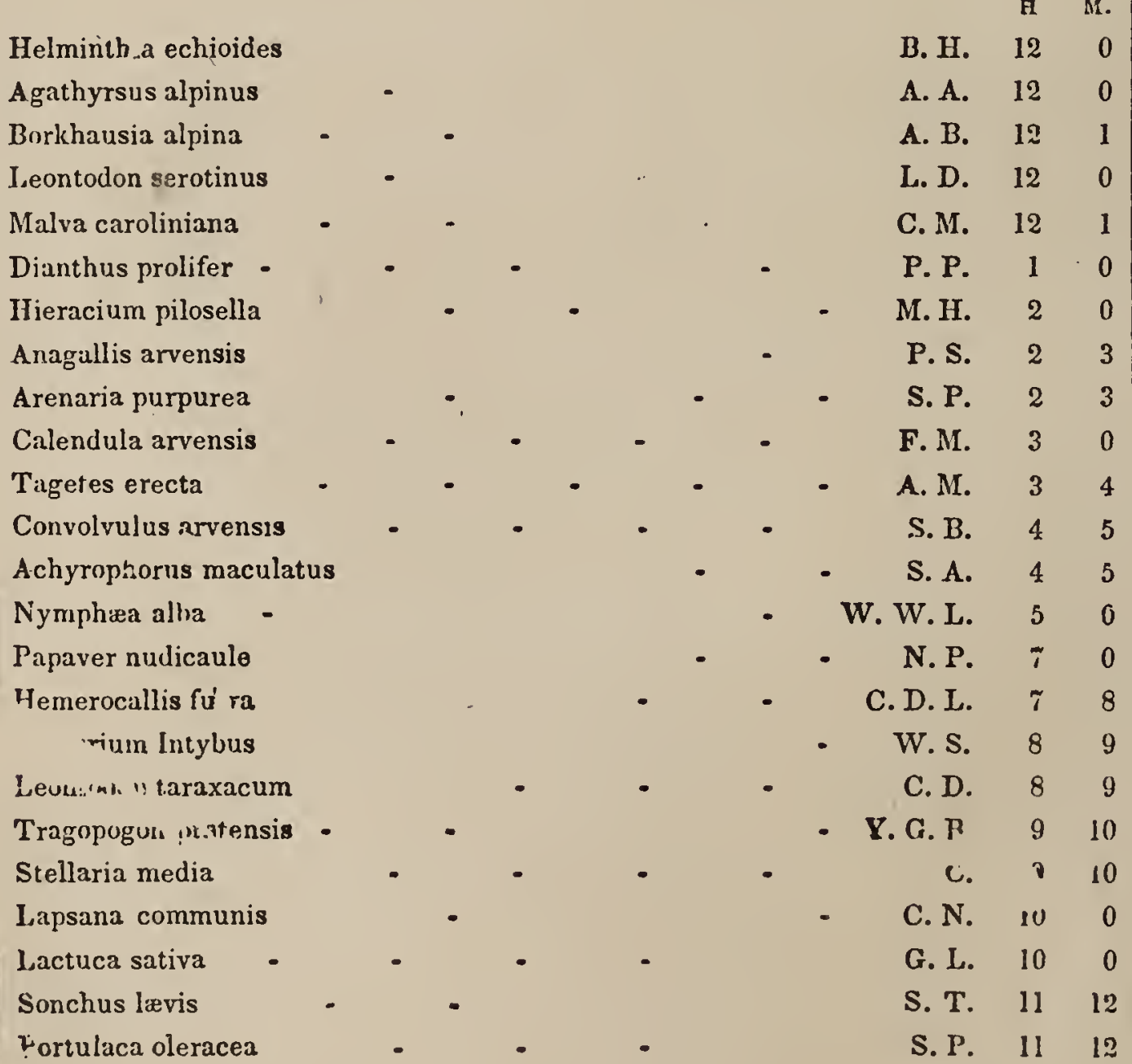

The tune here stated is from 3 Jon $\mathbf{t} 3$ night. 
Are to the noontide sun displayed,

But shut their plaits against the dew.

On upland slopes the shepherds mark

The hour, when, as the dial true,

Chiconium to the towering lark

Lifts her soft eyes serenely blue.

And thou "wee crimson tipped flower,"

Gatherest thy fringed mantle round

Thy bosom at the closing hour,

When night-drops bathe the turfy ground.

Unlike silené, who declines

The garish noontide's blazing light;

But when the evening crescent shines,

Gives all her sweetness to the night.

Thus in each flower and simple bell,

That in our path untrodden lie,

Are sweet remembrances, which tell

How fast their winged moments fly

SortTh.

The following beautiful lines are-ly Mrs. Hemans. They celebrate the far-famed dial of flowers constructed by Linnæus.

'T was a lovely thought to mark the hours, As they floated in light away,

By the opening and the folding flowers,

That laugh to the summer's day.

Thus had each moment its own rich hue,

And its graceful cup and bell,

In whose coloured vase might sleep the dew,

Like a pearl in an ocean-shell.

To such sweet signs might the time have flowed

In a golden current on, 
Ere from the garden, man's first abode, The glorious guests were gone.

So might the days have been brightly tord-

Those days of song and dreams -

When shepherds gathered their flocks of old,

By the blue Arcadian streams.

So in those isles of delight, that rest

Far off in a breezeless main,

Which many a bark, with a weary quest,

Has sought, but still in vain.

Yet is not life, in its real flight,

Marked thus - even thus - on earth,

By the closing of one nope's delight,

And another's gentle burth?

Oh ! let us live, so that flower by flower,

Shutting in turn, may leave

A lingerer still for the sunset hour,

A charm for the shaded eve.

And among other poets, we often meet with allusions to floral dials.

The dial hid by weeds and flowers,

Hath told, by none beheld, the solitary hours.

WIrsor.

Young Joy ne'er thought of cosnting hours.

'Till Care, one summer's morning,

Set up, among his smiling flowers,

A dial by way of warning.

MURrat.

What a wide field for the imagination is displayed in the succeeding quotation from Hartley Coleridge. We might fancy ourselves luxuriating in a garden of roses, where " every flower that blows" would add to our felicity; where the most agree- 
able and delightful companions were assembled to pass the hours in heedless pleasures - where no care - no sorrow - no unpleasant recollections of past disappointments - of hopes destroyed - or the overthrow of anticipated happiness - are allowed to interrupt our joy, and mar the beauty of the enchanted scene. Alas! these are but day-dreams, scattered by a breath. The rude realities of life - the continual frustration of long-rherished designs - and the constant blighting, if not extinction of our fondest hopes - all prove how utterly fallacious are the projects on which unassisted man attempts to construct a durable felicity. Read it! Does it not carry our 'ancy to an airy Eden?

\section{Shall I sing of happy hours}

Numbered by opening and cJosing flowers?

of smiles, and sighs that give no pain,

And seem as they were heard in vain -

Softly heard in leafy bowers,

Blent with the whispers of the vine,

The half blush of the eglantine,

And the pure sweetness of the jessamine;

What is it those sighs confess?

But we are extending this part beyond our limits. Flowers afford a certain means of determining the state of the atmosphere. "Many species are admirable barometers. Most of the bulbous-rooted flowers contract, or close their petals entirely, on the approach of rain. The African marigold indicates rain, if the corolia is closed after seven or eight in the morning. The common bindweed closes its flowers on the approach of rain; but the anagallis arvensis, or scarlet pimpernel," which we often call shepherd's weather-glass, "is the most sure in its mdications, as the petals constantly close on tre least humidity of the atmosphere. Barley is also singularly affected by the 
moisture or the dryness of the air. The awns are furnished with stiff points all turning toward one end; which extend when moist, and shorten when dry. The points, too, prevent their receding, so that they are drawn up or forward; as moisture is returned, they advance, and so on; indeed, they may actually be said to travel forward. The capsules of the geranium furnish admirable barometers. Fasten the beard, when fully ripe upon a stand, and it will twist itself, or untwist, according as the air is moist or dry. The flowers of the chickweed, convolvulus, and oxalis, or wood-sorrel, close their petals on the approach of rain."

Gardens have been the delight of poets in all ages. All our poets have sung of flowers. They serve all purposes; and we are reminded of the fable of the flowers, where the rose says -

What can a poet do without us?

"But it is not poets alone who half-worship flowers. What an enthusiastic devotion is that which sends a man from the attractions of home, the ties of neighbourhood, the bonds of country, to range plains, valleys, hills, and mountains, for a new flower! What a spirit must have animated Hermann, Hasselquist, Tournefort, Linnæus, Solander, Saussure, Humboldt, and hundreds of those who have sacrificed every personal convenience and selfish motive for the sake of illustrating the volume of nature, and opening almost a now existence upon those whose researches are necessarily limited. But the love of fiowers is not shared exclusively by the poet and the naturalist. Oh no! the little child loves the flower-garden, and watches with intense interest the early opening buds, such fair types of itself. The young, the middle-aged, and the hoary head, silvered with the snows of threescore years and ten; all, all hang 
with delight over the blooming parterre. The bud of infancy, the half-expanded flower of youth, the perfect blooms of the meridian of life, and the drooping leaves of closing existence, are here all seen and noted. No wonder that man, in the beautiful simplicity of earlier times, loved flowers, and hence formed an eloquent language, that spoke to the heart in a 'stıll, small voice,' more touching than the tenderest accents. No wonder that the most lovely ornament for the young virgin was a chaplet of fair flowers; the most glorious distinction of the warrior a wreath of bays. No wonder that the bier of the early dead was strewed with these passing emblems of a passing existence."

May-day - May-day, that revives such joyful reminiscences of our childhood-bringing back to us the pleasures of "bypast time," in remembrance and reality, May-day must not be forgotten.

Hail! thou of ever-circling time,

That gracest still the ceaseless flow !

Bright blossoms of the season's prime,

Aye hastening on to winter's snow !

Hail ! thou, the fleet year's pride and prime!

Hail ! day, which fame should bid to bloom!

Hail! image of primeval time!

Hail ! sample of a world to come !

LANGHORNE.

"The flowery month of May," says Peacham, "must be drawn as a youth, with a sweet and amiable countenance, clad in a robe of white and green, embroidered with daffodils, hawthorns, and blue-bottles; upon his head a garland of white, damask, and red roses; in one hand a lute; upon the fore-finger of the other a nightingale; and the sign Gemini in the background." 
May-day festivities are now falling rapidly into disuse; but in ancient times it was celebrated as was fitting by the young. They rose shortly after midnight, and went to some neighbouring 'wood, attended by songs and music, there breaking green branches from the trees, and making nosegays, wreaths, ano crowns of flowers. They returned home at the rising of the sun, and made their windows and their doors gay with garlands. In the villages they danced during the day round the May-pole, which afterward remained the whole year untouched, except by the seasons, a fading emblem, and a consecrated offering to the goddess of flowers." Chaucer, in his conclusion of the Couit of Love, hath described the feast of May.

Forth goth all the court, both inost and least, To fetch the floures fresh, and braunch and blome.And namely hawthorn brought both page and grome, And then rejoysen in their great delite,

Eke ech at others threw the floures bright, The primrose, riolete, ard the gold,

With fresh garlants party blue and white.

To pass, however, more immediately to the contents of this work, we would observe, that the sentimental language of Flora is by no means of modern invention. "The hieroglyphics of the ancient Egyptians abound in floral symbols, and from hence we may surmise that the Greeks became accustomed to this figurative language. Their poetical fables are full of the metamorphoses of their deities into plants; indeed, there was no flower to which their imaginations had not affixed some meaning; even to this day a young Arcadian is seldom :seen without his turban full of flowers, presented to him by the beauty he admires, by the silent language of which his hopes are kept alive; and it forms one of the chief amusemerits of the Greek girls to drop these symbols of their esteem 
or scorn, upon the various passengers who pass their latticed windows."

In the gardens of the East, Flora receives the homagc due for her widely-scattered and various gifts. Oh! flowersflowers - we may well think them the "alphabet of the angels." But how coldly do we look on them; how often are we regardless of their charms here; while in other lands they almost subserve the use of writing-expressing by a blossom, joy, grief, hope, despair, devotion, piety, and almost every sentiment that fills the mind.

In Eastern lands they talk in flowers,

And they tell in a garland their loves and cares;

Each blossom that blooms in their garden bowers,

On its leaves a mystic language bears.

The rose is the sign of joy and love,

Young blushing love in its earliest dawn

And the mildness that suits the gentle dove,

From the myrtle's snowy flower is drawn.

Innocence dwells in the lily's bell,

Pure as a heart in its native heaven;

Fame's bright star and glory's swell,

By the glossy leaf of the bay are given.

The silent, soft, and humble heart

In the violet's hidden sweetness breathes;

And the tewler soul that cannot part,

A twine of evergreen fondly wreathes.

The cypress that darkly shades the grave,

Is sorrow that mourns its bitter lot;

And faith that a thousand ills can brave,

Speaks in thy blue leaves, Forget-me-not.

Then gather a wreath from the garden bowe's,

And tell the wish of thy heart in flowers.

Percifar. 
Lady M. W. Montague was one of the first to introduce fioral language into Europe. When at Pera, she sent a Turkish love-letter to a friend in England, from which we extract the botanical emblems.

Clove. You are as slender as this clove!

You are an unblown rose!

I have long loved you, and you have not known it.

IONQUIL. Have pity on my passion!

PEAR. Give me sume hope!

A Rose. May you be pleased, and your sorrows mine!

A straw. Suffer me to be your slave!

Crnsamon. But my fortune is yours !

Pepper. Send me an answer!

Her ladyship states that there is no flower without a verse belonging to it; and that it is possible to quarrel, reproach, or send letters of passion, friendship, or civility, or even of news, without ever inking the fingers.

Happy the young and light-hearted maiden who ignorant of the silly pleasures of the world, feels no occupation to be more agreeable than the study of plants. She seeks in the field her nusst touching ornaments; each spring brings to her new joys: and every morning a fresh harvest of flowers repays her diligent cultivation; a garden is to her an inexhaustible source of delight and instruction. By a charming art these beautiful productions of nature are converted into liquid perfumes, precious essences, or valuable conserves. One of the most delightful accomplishments that can be chosen for the fair sex is that of catching the transient shades of beauty which are found upon flowers, and fixing them on prper. The able pencil 
shows to us the queen of spring with her spherical form, her delicate colours, the beautiful green of her foliage, the thurns which protect her, the dew-drops which bathe her, and the butterfly which skims lightly over her beautiful form. "The beauty and grace that may be displayed in grouping fiowers, united with the gayety of their colours, and the harmony of their tints, are objects well worthy the attention of those who were born to render life delightful." Nothing is forgotten in depicting them; and when we look upon the faithful representative, even in the depths of winter, we may fancy that we inhale the perfumes of spring. This study, in imparting a taste for all that is beautiful in nature, fills the soul witb ravishing emotions, and opens before us the enchanted avenues of a world full of wonders." "Flowers," says Pliny, "are the joy of the shrubs which bear them." This eminent observer of nature might also have added, "and of those who love them and cultivate them."

The interpreters of our sweetest sentiments, flowers lend their charms even to love - to that pure and chaste affection, which, as Plato observes, is an inspiration from the gods. The expression of this divine passion ought to be divine also, and it was to illustrate this that flowers were ingeniously made emblematical of our most delicate sentiments; they do, in fact, utter in "silent eloquence" a language better than writing; they are the delicate symbols of the illusions of a tender heart and of a lively and brilliant imagination. In the glorious days of chivalry, the respectful lover oft made use of the sweet language of flowers. Gothic books ar full of emblems composed of flowers; and we find, in the romance of Perceforét, that a garland of roses is the lover's treasure. We read also in that of Amadis, that Oriana, a prisoner who had neither the opportunity of speaking nor writing to her lover, apprised him of her misfortune by throwing, from the high tower in which she was 
confined, a rose bathed in her tears. What a charming expression of sorrow and of love! The Chinese have an alphabet composed entirely of plants and roots; and we may yet read upon the rocks of Egypt the ancient conquests over that people, recorded by foreign plants. This language is as old as the world, but its characters are renewed in each succeeding spring.

Should a beautiful odalisk wish to avenge herself on a tyrant who has treated her with cruelty, she may, with a single floweret of the lily of the valley, thrown as by chance, inform a young icoglan, that the favourite sultana, weary of her tyrannous lord, wishes to inspire a sentiment of lively and pure affection. If he should return a rose, it would be as though he had said that reason was opposed to her projects; but a tulip, with a black heart, and flame-coloured petals, would assure her that her wishes were understood and partaken of. This is an ingenious mode of correspondence, which can never betray nor divulge a secret.

This eloquent language gives a charm to the sweet intercourse of friendship, and to filial and maternal love; it adds to the delight of youthful affections, and affords an excellent mode of recognition. The unfortunate may even find a faithful messenger in a flower. Roucher, when in solitary confinement, consoled himself in studying the flowers which his daughter collected for him; and, a few days before his death, he sent her two dead lilies, to express, at the same time, the purity of his soul and the fate which awaited him.

The poet Saadi, author of "Gulistan, or the Rose-Garden," engaged to break his chains by presenting a rose to the man who owned him as his slave. He said, "Do good unto thy servant while thou hast it in thy power, for the season of power is often as brief as the existence of this beautiful flower."

The sentiments and emblems found in this volume are chiefly 
derived from the ancients and especially from Eastern nations. In pursuing the research, it has been found that time, instead of rendering their sentiments less appropriate, has confirmed their fitness, and continually added new charms to the language. Little study is necessary in the science here taught; nature has been before us. It will suffice that two or three rules be given, which the reader will do well first to learn, and then by reference to the work, which is systematicaily arranged for the pur-. pose, he will be enabled to converse in the language of flowers. By the first rule, a flower presented inclining to the right, expresses a thought; reversed, it is understood to convey the contrary of that sentiment. For example:-A rosebud, with its thorns and leaves, is understood to say, "I fear, but I hope." The same rosebud reversed, would signify that "You must neither fear nor hope." You may convey your sentiments very well by a single flower. As the second rule, take the rosebud which has already served us for an example, and strip it of its thorns, it tells you that "There is everything to hope." Strip it of its leaves, it will express that "There is everything to fear."

The expression of nearly all flowers may te varied by changing their position. Thus, the marigold, for example: placed upon the head, it signifies "distress of mind;" upon the heart, "the pains of love;" upon the breast, "ennui." It is also necessary to know that the pronoun $I$ is understood by inclining the flower to the right, and the pronoun thouby inclining it to the left.

Such are the first principles of this mysterious language. Love and friendship ought to join their discoveries to render it more periect: these sentiments, the most delightful in nature, are alone able to perfect what they have originated. 
$\mathrm{OH}$ ! thou magic world of flowers,

Fairy ministers of grace,

Soothing all our weary hours,

Decking every lonely place

With a teinting bright and strange,

Glowing in a world of change.

Hidden links of some fair sphere,

Breathing of its hues of light,

Ye have holy spells and dear,

Ye have toliens for the sight;

The spell of love, the voice of power,

May thrill us from a fragile flower.

Seek we an emblem of our dreams,

of hopes we fondly hide-

Behold! the water-lily gleams,

Half trembling on the tide:

And once beneath the ploughshare wild,

The mountain-daisy looked and smiled.

Thus should the cheek of beauty glow,

At tales too fond, too true,

Twine ye the myrtle for her brow

With rose of brightest hue,

And whisper that in Eastern bowers

They learn the Poetry of Flowers!

Lucy Hoofer. 
THE

\title{
POETRY OF FLOWERS
}

\author{
$A N D$
}

\section{FLOWERS OF POETRY}

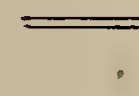

\section{A B SEN CE.}

WORMITOOD.

WORMrwood is considered the bitterest of plants. Its scientific name, Absinthium, is derived from the Greek and signifieswithout siveetness. It is therefore very appropriately made the emblem of absence; which according to La Fontaine, is the greatest of evils.

He told me he would come again

When summer's last wild roses bloom,

And when we parted in the glen

The young houstonia shed perfume.

I thought how many flowers must spring While I my absent love deplore;

I could not bear that early thing Should not have faded long before. 
But iast the scented violets grew, And blue rhodora with them stood; And then the rose-bay-laurel blew, And white viburnum of the wood.

And now the light, midsummer air

Breathes of the swamp-pink and sweet-fern The lily-bells have withered there-

I know my love will soon return!

Fast fades the long-lived meadow-sweet,

I joy to see it pass away,

But when I with my true love meet, Long - long may autumn roses stay!

\section{Mirleter.}

\section{A RTS (THE).}

ACANTHUS.

Trie Acanthus is found in hot countries along the shores of great rivers.

"Le nil du vert acanthe admire le feuillage."

The ancients tactefully adorned their furniture, vases, and most costly attire, with its elegant leaves. And Virgil writes, that the robe of Helen was bordered with a wreath of acanthus in relief.

This beautiful model of the arts has become their emblem; and he will be talented indeed, who shall produce anything to excel its richness. If any obstacle resists the growth of the acanthus, it seems to struggle to overcome it and to vegeiate with renewed vigour. So genius, when acted upon by resist- 
ance or opposition redoubles its attempts to overthrow every impediment.

It is said that the architect Callimach, passing near the tomb of a young maiden who had died a few days before the time appointed for her nuptials, moved by tenderness and pity approached to scatter some flowers upon her tomb. Another tribute to her memory had preceded his. Her nurse had collected the flowers which should have decked her on her wedding day and putting them with the marriage veil in a little basket had placed it near the grave upon a plant of acanthus, and then covered it with a tile. In the succeeding spring the leaves of the acanthus grew round the basket; but being staid in their growth by the projecting tile, they recoiled and surmounted its extremities. Callimach, surprised by this rural decoration, which seemed the work of the Graces in tears, zonceived the capital of the Corinthian column; a magnificent ornanient still used and admired by the whole civilized world.

When from the sacred garden driven,

Man fled before his maker's wrath,

An angel left her place in Heaven,

'And crossed the wanderer's sunless path,

'T was Art, sweet art! new radiance broke,

Where her light foot flew o'er the ground,

And thus with seraph voice she spoke-

"The curse, a blessing shall be found!"

He rends the oak and bids it ride,

To guard the shores its beauty graced,

IIe smites the rock - upheaved in pride,

See towers of strength and domes of taste!

Sprague. 
A S S I G A T ION.

PINIPERNEL.

The common Fimpernel is a besutiful trading weed and one of the Flore Horologice, opening its. flowers regularly about eight minutes past seven o'clock, and closing them about three minutes past two o'clock. It serves also as an hydrometer; for if rain fall, or there be much moisture in the atmosphere, the flowers either do not open or close up again. It is frequently called the shepherd's weather-glass.

Our bonny Kate bound her golden hair, With a violet wreath for the village-fair, And tripped with the grace of a gay gazelle, Where blushes the delicate pimpernel; For a prophetess true is that lowly flower, She warns us ever of tempest hour, When the rain-cloud shadows her humble head, She folds her petals of brilliant red, And heeps her sunny heart warm within, Like a fair girl shutting out grief and sin.

F. S. 0 .

When the sun o'er yonder mountain,

Smiles farewell to earth and sky, Meet me Marion, where our fountain Soflly sings its lullaby! 


\section{A S YLU M-PROTERTION.}

\section{JUNTPER.}

THE ancients consecrated this shrub to the Eumenides. The smoke of its green branches was the incense which, in preference, they chose to offer to the infernal gods; and burnt its berries on funeral orcasions to drive away evil spirits. The simple villagers of England superstitiously believe that the perfume of its berries purifies the air and protects them from the malevolence of wicked genii.

Its thick branches bristling with thorns are covered with thousands of brilliant insects, which seem to imagine, this tree is provided as a protection for their weakness.

It is said that the powerful odour emitted by the juniper defeats the keen scent of the hound. It thus affords a safe retreat to the huited hare, which, in the last extremity conceals itself beneath its protecting branches.

Ah no! never deem her less worthy of love,

That once she has trusted and trusted in vain, Would you turn from the timid and innocent dove,

If it flew to your breast from a savage's chain.

She too is a dove in her guileless affection,

A child in confiding and worshipping truth, Half broken in heart she has flown for protection

To you!- Will you blight the sweet promise of youth?

F. S. 0 . 


\section{BEAUTY COMBINED WITH PIETY.}

WATER-STAR.

"This flower grows in fresh water, supported by its floatmg upper leaves, which form star-like tufts on the ends of the stem." "Flowering above, but ripening its seeds 'nder water," it seems an apt emblem of a lovely girl, who, while sine does not neglect her external bloom - the flower of health and beauty - still cherishes, within, the seeds of virtue to blossom in a future life.

All beaming with light as those young features are, There's a light round thy heart, that is lovelier far; It is not that cheek-it is the soul dawning clear; Through its innocent blush, makes thy beauty so dearAs the sky we look up to, though glorious and fair, Is looked up to the more, because Heaven is there!

Moore.

As lightly floats the water-star,

And gems the limpid stream, Thy graceful, radiant loveliness,

A star of earth doth beam!

As 'neath the wave its seeds are nursed,

For future bloom above,

Within thy soul, thou cherishest

Hope, meekness, faith, and love:

And like the germ, that soul shall rise,

When earth's cold bonds are riven,

Inhale the light in cloudless skies,

And bloom - a star of heavien!

F. S. 0 . 


\section{BONDS OF L OVE.}

HONEYSUCKLE.

Tre Iloneysuckle sometimes attaches its pliant branches to the knotted trunk of an ancient oak, and amid the rugged branches of that lordly tree,

The woodbines mix, in amorous pla

And breathe their fragrant lives away

It was said, that this feeble tree, thus shooting in to the air, would overtop the king of the forest; but, as if its efforts were unavailing, it soon recoiled, and, with graceful negligence, adorned its friendly supporter, with elegant festoons and perfumed garlands.

Fragile but sweet is the woodbine wild, Clinging wherever its beauty may rest, Fair as the woodbine, as trusting and mild, Oh! be thy home upon Love's fond breast!

S. 0

B E A U T Y.

ROSE.

Rose! thou art the sweetest flower, That ever drank the amber shower; Rose! thou art the fondest child of dimpled spring, the wood-nymph wild!

MiOORE'S ATACREON.

THIs beautiful flower, and universal favourite of nature, has never been described in language adequate to convey an idea 
of its charms, although each poet in turn has made it the theme of song, or introduced eulogiums on its beauty to heighten the attractions of his poesy.

Not one of all the train has, however, been able to do justice to its merits, though they have denominated it the daughter of heaven, the ornament of the earth, and the glory of spring.

When it opens its delicate buds, the eye surveys its harmonious outlines with delight. But how shall we describe the delicate tints of its enchanting colours, or the sweet perfume which it exhales? Behold, in the spring it raises itself softly in the midst of its elegant foliage, surrounded by its numerous buds. This, the queen of flowers, and the pride of Flora, seems to sport with the air that fans her, to deck herself with the dew-drops that impearl her, and to smile upon the rays of the sury which cause the expansion of her beautiful form

Proud be the rose, with rains and dews

Her head impearling.

WORDSWORTH.

In producing this flower, nature appears to have exhausted herself by her prodigality, in attempting to produce so fine a specimen of freshness, of beauty in form, of exquisite perfume, of brilliancy of colour, and of grace. The rose adorns the the whole earth, as it is the commonest of flowers. The same day that its beauty is perfected it dies; but each spring restores it to us with renewed freshness. Poets have had fair opportunities for singing its praises, yet they have not rendered its eulogy common-place, but its name alone redeems their names from forgetfulness. Emblem of all ages-interpreter of all our sentiments - the rose mingles in the gayety of our feasts, in our happiness, and in our sorrows. It is also the ornament of beauty, and lends its soft carnation hues to the blush of modesty. It is given as the prize of virtue; and is the image of youth, of innocence, and of pleasure. Venus is said to feel that she has a rival in the rose, as it possesses, like her, a grace which is mor: lovely than beauty itself. 
Anacreon, the poet of love, has celebrated the rose; and, perhaps, he has sung its praise more worthily than any of his successors. Moore has thus translated the Ode.

While we invoke the wreathed spring,

Resplendent rose! to thee we 'll sing;

Resplendent rose, the flower of flowers,

Whose breath perfumes Olympus' bowels'

Whose virgin blush, of chastened dye,

Enchants so much our mortal eye.

When pleasure's bloomy season glows,

The Graces love to twine the rose;

The rose is warm Dione's bliss,

And flushes like Dione's kiss!

Oft has the poet's magic tongue

The rose's fair luxuriance sung:

And long the Iifuses, heavenly maids,

Have reared it in their tuneful shades.

When, at the early glance of morn,

It sleeps upon the glittering thorn,

'T is sweet to dare the tangled fence,

To cull the timid floweret thence,

And wipe with tender hand away

The tear that on its blushes lay;

'Tis sweet to hold the infant stems,

Yet dropping with Aurora's gems,

And fresh inhale the spicy sighs

That from the weeping buds arise.

When revel reigns, when mirth is high,

And Bacchus beams in every eye,

Our rosy fillets scent exhale,

And fill with balm the fainting gale. 
Oh ! there is naught in nature bright, Where roses do not shed their light! When morning paints the orient skies, Her fingers burn with roseate dyes; The nymphs display the rose's charms, It mantles o'er their graceful arms; Through Cytherea's form it glows, And mingles with the living snows. The rose distils a healing balm, The beating pulse of pain to calm; Preserves the cold inurned clay, And mocks the vestige of decay; And when at length, in pain decline, Its florid beauties fade and pine, Sweet as in youth, its balmy breath Diffuses odour e'en .in death !

Oh! whence could such a plant have sprung? Attend - for thus the tale is sung:When, humid, from the silvery stream, Effusion beauty's warmest beams, Venus appeared in flushing hues, Mellowed by ocean's briny dews; When, in the starry courts above, The pregnant brain of mighty Jove Disclosed the nymph of azure glance, The nymph who shakes the martial lance! Then, then, in strange eventful hour, The earth produced an infant flower, Which sprung, witl blushing tinctures drest, And wantoned o'er ts parent breast. The gods beheld this brilliant birth, And hailed the Rose, the boon of earth! 
With nectar drops, a ruby tide, The sweetly orient buds they dyed. And bade them bloom, the flowers divine Of him who sheds the teeming vine; And bade them on the spangled thorn Expand their bosoms to the morn.

Jami, an eastern poet, says, "You may place a hundred handfuls of fragrant herbs and flowers before the rightingale; yet he wishes not, in his constant heart, for more than the sweet breath of his beloved rose."

Oh, sooner shall the rose of May

Mistake her own sweet nightingale;

And, to some meaner minstrel's lay

Open her bosom's glowing veil,

Then love shall ever doubt alone,

A breath of his beloved one.

MoORE.

And James Montgomery says, in that sweet collection the Portfolio:-

Where the true-lne nightingale,

Woos the rose in every vale.

The following anecdote is narrated by Mr. Phillips, in his "Sylva Florifera," of the birth of the rose:- "Flora having found the corpse of a favourite nymph, whose beauty of person was only surpassed by the purity of her heart and chastity of her mind, resolved to raise a plant from the precious remains of this daughter of the Dryads, for which purpose she begged the assistance of Venus and the Graces, as well as of all the deitıes that preside over gardens, to assist in the transformation of the nymph into a flower that was to be by them proclaimed queen of all the vegetable beauties. The ceremony was attended by the zephyrs, who cleared the atmosphere, in order 
that Apollo might bless the new-created progeny by his beams. Bacchus supplied rivers of nectar to nourish it : and Vertumnus poured his choicest perfumes over the plant. When the metamorphosis was complete, Pomona strewed her fruit over the young branches, which were then 'crowned by Flora with a diadem that had been purposely prepared by the celestials to distinguish this queen of flowers."

Moore in his Irish Melodies, gives us a poetical reason for the beauty and delicious perfume of the rose. Others have stated that Love, in a feast of Olympus, in the midst of a light and lively dance, overthrew, with a stroke of his wing, a cup of nectar; which precious liquor, falling on the rose, embalmed it with that delightful fragrance which it still retains.

They tell us that love in his fairy bower

Had two blush roses; of birth divine;

He sprinkled the one with a rainbow's shower,

But bathed the other with mantling wine.

Soon did the buds,

That drank of the floods

Distilled by the rainbow, decline and fade;

While those which the tide

Of ruby had dyed

All blushed into beauty, like thee, sweet maid!

Moore.

Light, lovely limbs, to which the spirit's play Gave motion, airy as the rancing spray,

When from its stem the small bird wings away. Lips, in whose rosy labyrinth, when she smiled, The soul was lost; and blushes swift and will, As are the momentary meteors sent Across the uncalm, but beauteous firmament; 
AND FLOWERS OF POETRY.

And then her look! - oh! where's the heart so wise, Could unbewildered meet those matchless eyes?

Moore.

Her cheer was very eloquent;

In passion, pride, or shame,

Like summer's warmest lightning flash,

The colour to it came; -

In joy - swift smiles and dimples broke

Upon its pure repose,

Like sunshine and a zephyr,

At play upon a rose.

THE ROSE IN ICE.

She has a glowing heart, they say,

Though calm her seeming be,

And oft that warm heart's lovely play,

Upon her cheek, I see.

Her cheek is almost always pale,

And marble-cold it seems;

But a soft colour quivers there,

At times in rosy gleams;

Some sudden throb of love or grief.

Or pity or delight-

And lo! a flush of beauty, brief,

But passionately bright!

She 'minds me of a rose I found,

In a far southern land, 
A robe of ice, its blushes, bound, By winter-breezes fanned.

But softly through the crystal veil, That gleamed about 'ts form, There came a fitful glow to tell, The flower beneath was warm: And thus, though cold her seeming be,

Her cheek so calmy fair, Her spirit, struggling to be free, Doth often tremble there!

\section{BEAUTY EVER NEW. \\ CHINA, OR MIONTHLY ROSE.}

THIs is the earliest flowering rose; and in mild seasons when planted against a wall, will sometimes flower in the beginning of April; and being protected by glass in Autumn, or aided by artificial heat, may be continued in bloom until Christmas.

That loveliness ever in motion, which plays,

Like the light upon Autumn's soft, shadowy days, Now here and now here, giving warmth as it flies, From the lips to the sheeks, from the cheek to the eyes! liIOORE.

An angel face! its sunny "wealth of hair," In radiant ripples, bathed the graceful throat And dimpled shoulders;-round the rosy curve Of the sweet mouth a smile seemed wandering ever, 


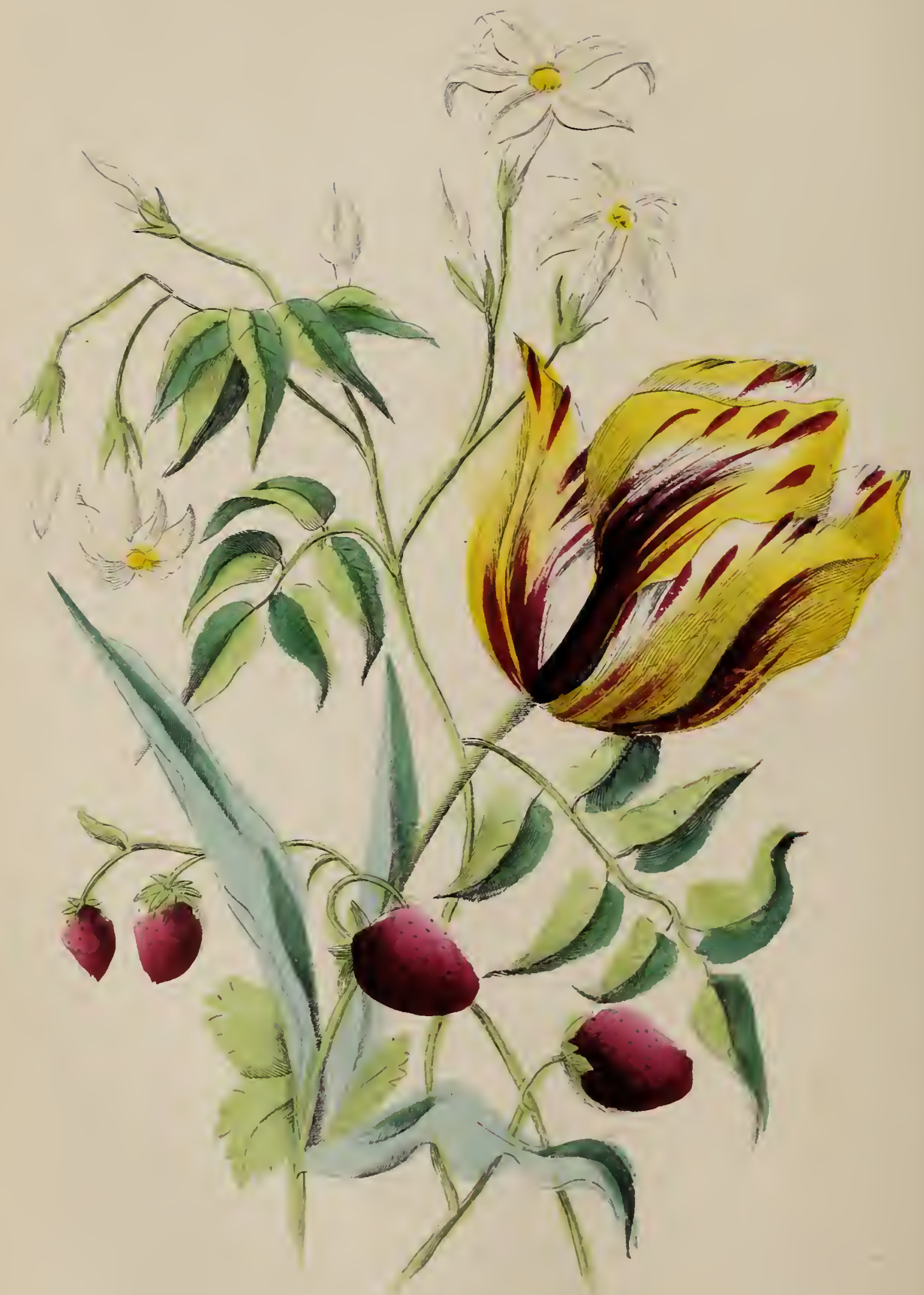


While in the depths of azure fire, that gleamed

Beneath the drooping lashes, slept a world Of eloquent meaning - passionate but pure, Dreamy, subdued, but oh ' how beautiful!

\section{$C \& L U M N$}

II ADDER.

A sCARLET dye is produced from madder, and is of very common use among dyers. When sheep have browsed on this plant their teeth appear stained, as if in the blood of some victim. The vile calumniator often takes advantage of dubious appearances to cast a stigma upon innocence itself. It has been observed that the bones of all animals feeding upon it become red, the hardest parts changing first, until the whole substance is coloured.

Be thou as chaste as ice, as pure as snow Thou shalt not escape calumny!

SHIAKSPEARE.

\section{H A S T I T Y. \\ OKA TGE FLOWER.}

IT is the custom in France, for the newly-married to wear a head-dress of orange flowers. Formerly a dishonoured girl was deprived of this ornament on her wedding-day; and this vage still exists in the neighbourhood of Paris. 
Chasie as the icicle

That's curdled by the frost from purest snow, And hangs on Dian's temple.

SHATSPEARE.

How fair the orange-bloom will smile, Amid that auburn braid!

How soft will burn thy blush the while,

Beneath the bridal shade!

Thou'rt young to wed! - that virgin flower,

White as thine own pure brow:

Just stolen from its dewy bower,

Is not more fresh than thou.

Thou 'rt young to wear the bridal-bloom,

Yet go! for in thy heart,

A lovelier blossom lights the gloom,

That timid fears impart. -

The heaven-fed flower of Purity;-

Oh! nurse the snowdrop still!

And in its breath, a charm shall be,

To guard thee from all ill.

F. S. O.

COLDNESS-TO LIVE TVITHOUT LOVE.

\section{AGNUS CASTUS.}

Dioscorides, Pliny, and Galen inform us, that the priestesses of Ceres formed their virginal couch of the fragrant branches of the Agnus Castus, which is an autumnal shrub with whor- 
led spikes of blue and white flowers from seven to fifteen inches long. This they regarded as the palladium of their chastity. In modern times, the religious orders of France drink a water distilled from its branches, to dispel from their minds, when in solitude, all earthly thoughts. Many orders of monks habitually wear a knife whose haft is made of the wood of agnus castus, to fortify their hearts against external influence. In fine this pretty shrub has been from time immemorial the emblem of coldness.

The frigid' and unfeeling thrive the best, And a warm heart in this cold world is like A beacon light, wasting its feeb!e frame, Upon the wintry deep, that feels it not, And trembling, with each pitiless gust, that blows, Till its faint fire is spent.

Henry Neele.

\section{CONSOLATION.}

\section{SNOWDROP.}

Tine north wind whistles, and the hoar-frost clothes the verdure-despoiled trees; an uniform white carpet covers the earth - the birds withhold their tuneful song - and the sealed waters cease to murmur as they roll; the rays of the sun, enfeebled by the density of our atmosphere, shed a gloomy light over our fields; and the heart of man is sad while all nature reposes in torpid tranquillity.

Thus Madame de la Tour describes the state of nature, when suddenly a delicate flower pierces the veil of snow which had 
concealed it. It has been aptly termed by her countrymen Perce-neige, from the quality just named; and is with equal propriety called snowdrop by us.

Though cold Fate has lowered

And darkened my day;

Though sorrow has showered

Her tears o'er my way;

One blossom has flowered,

In Love's sunny ray.

Let Fate then bereave me,

Let other friends flee,

If my snowdrop she leave me,

Pure, smiling, and free,

No more can she grieve me-

My hope is in thee!

F. S. 0 .

\section{CONSOLATION OF SLEEP.}

\section{POPPY.}

The poppy yields a narcotic juice in considerable quantity, which is frequenily administered to procure sleep and relieve pain; on this account it has been made the symbol of consolation. The ancients, who regarded sleep as the great physisian, and the great consoler of human nature, crowned the god of sleep with a wreath of poppies. 
One, with her flushed cheek laid on her white arm, And raven ringlets gathered in dark crowd Above her brow, lay dreaming soft and warm.

\section{BIRON.}

Sleep, that knits up the ravelled sleeve of care.

SHAKSPEARE.

Glad for a wnile to heave unconscicus breath, Yet wake to wrestle with the dread of death.

BYron.

\section{O N T A N C Y.}

\section{BLUE CANTERBURY-BELL.}

Turs beautiful flower, from the depth and richness of its colour, has been made the emblem of constancy. It is a very ornamental border-flower, and is of easy culture.

Through the fragrant grove of olives, with a dark-eyed child of Spain,

I have often whiled the hours, since I crossed the moaning main ;

But the soul in those soft, brilliant eyes, the low, meloarous tone,

I Bade mournful thoughts of thee arise, my beautiful, my own!

'Mid the vines of sunny France, ove, I have twined the silken curl,

And met the merry kisses, of a light and laughing girl, 
And richly wared the glittering tress, and wildly woke her glee!-

I pined the more for thy caress - more fondly thought of thee!

A haughty, high-born English maid, oft shares, with me, the dance; -

Italia's daughter bends on me, her full, impassioned glance;Nor graceful mein - nor dimpled bloom - nor look of loving light,

Can win this faithful soul from thee, my purest, and most bright!

F. S. 0 .

\section{O Q UETR Y.}

YELLOW DAY-LILY.

THE flowers of this plant speedily fade, seldom contmuing two days in bloom; for this reason it has been assigned as the emblem of coquetry. As an equivalent for the transient duration of its flowers, it displays its beauty by a continual succession of blossom, and gives out for some time a very agreeable odour; and this the more nowerfully when planted in shady or moist situations.

I sunned myself once in her smile:-

She has turned its soft beam upon one,

Who cares not a pin for her-while

He triumphs and I am undone! 
I lived on the sweets of her lips;-

I must seek for a supper elsewhere;-

Another that banquet may sip!

Another may play with her hair!

And why is my rival so dear?

And why is she out when I call?-

His income's five thousand a year!

And mine-it is-nothing at all!

F. S. O,

\section{COME DOW N TO ME.}

\section{JACOB'S LADDER.}

THERE are but two species of this pretty flower as yet known; one belonging to North America - the other common to Europe and Asia. Its flowers vary from blue to white.

Look! how the stars like jewels glisten, Maiden, more pure than gem or star!

Lean from thy lattice, my love, and listen, While I awake my wild guitar.

See! I have flung a fair flower to thee, May not its name my fond hope tell? Oh! for thy lover, let it woo thee!

And ask thy blush what it means, "ma belle!"

Last night, the patriarch's dream was mine:-An angel came from heaven to me;- 
Its smile - its tresses - were so like thine, I think it could have been r.one but thee!

Then realize, love, that radiant dream, Fly from thy iyrant's savage pride! Descend - oh! seraph ! by night's dim beam, And morn shall hail, with a smile, my bride! F. S. 0 .

\section{O N J G A L O VE.}

LINDEN-TREE.

BaUcis was changed into the Linden-tree, which has ever since been the emblem of conjugal love. In glancing over the consecrated plants in the mythology of the ancients, we cannot fail to admire their fitness to represent the various qualities of which they are symbolical.

Beauty - grace - simplicity - an exireme softness of manner, and an innocent gayety, should be, in all ages, the properties and accomplishments of a tender wire. We find all these qualities united in the Linden-tree; which, in spring, is ever covered with a soft and delicate verdure, and exhales a very deligh ifu' fragrance, while it lavishes the honey of its flowers upon the busy bee.

Who shall attempt to paint the effect of its beautiful foliage as it waves its branches softly under the influence of the breeze? Its young leaves seem to have been cut of softer materials than silk, and are far more brilliant. We can scarce cease to gaze upon its vast shade; nay, we could wish to be always repusing under it - to listen to the murmurs of its branches, and breathe its delicious perfumes. The magnificent chestnut and the slender acacia have each disputed the right of the Linden-tree, to 
hold a place in the public avenues and promenades; but they and fashion unted have not succeeded in banishing it thence.

Yes! the pure, open, prosperous love, That, pledged on earth and sealed above, Grows in the world's approving eyes, In friendship's smile and home's caress, Gillecting all the heart's sweet ties

Into one knot of happiness!

MOORE.

The earth was sad-the garden was a wildAnd man - the hermit-sighed, till woman smiled!

CAMIPBer.L.

That union where all that in woman is kind,

With all that in man most ennoblingly towers, Grow wreathed into one-like the column, combined Of the strength of the shaft and the capital's flowers.

Moore.

Calm wedded affection, that home-rooted plant, Which sweeten seclusion, and smiles in the shade.

MOORE.

I do not promise that our life

Shall know no shade on heart or brow;

For human lot and mortal strife

Would mock the falsehood of such vow.

But when the clouds of pain and care

Shall teach us we are not divine,

My deepest sorrows thou shalt share,

And I will strive to lighten thine.

Eliza Coon. 


\section{R U E T T}

\section{NETTLE:}

THE sting of the nettle causes a pain as violent as that produced by a burn. On examining the plants with a microscope, we observe "the projecting bristles or prickles with which they are covered, are tubular and stand on a bag filled with poisonous juice; they are perforated at the point, and when they are gently pressed verticaily, the pressure at once forces the poison to ascend the tube, and enables the point to lodge it in the skin."

Its generic name, Urtica, is formed from uro, to burn, in a!lusion to its stinging properties.

More cruel far than murder's self is he,

Who, having kindled once love's Eden-bloom,

With warm Persuasion's spell, in some young heart,

E'er lets Indifference blight it or Neglect;-

For Love - true Love can flower but once in life,

In woman's life - the Alue of her heart!

F. S. 0 .

\section{E L I C A C Y.}

\section{BLUE-BOTTLE CENTAUTY.}

The beautiful blue of this flower, which is of the colour of an unclouded sky, has made it the emblem of a tender and lelicaté sentiment, nourished by hope.

Her love is pure and glad ais true, As yonder heaven of stainless blue. 


\section{IL L USTRATION OF PLATE.}

\section{Jasmine.-Strawberry.-Tulip}

Your amiability, and the excellence of your character, have comfelled me to declare my love.

'Twas not the glossy, golden flow

Of tresses richly braided,

'Twas not the dimpled rose below,

'Whose soul-fed smile they shaded!

Those dark-fringed eyes of brilliant blue,

Whose glances talk in light, love,

Thy fragrant lips' deep, carmine hue,

Thy hand so soft and slight, love;

It was not these-though these excel,

In thee, all others' beauty;-

It was not these, that wove the spell, And won my love and duty.

Thy heart is like the Jasmine-bell,

It yields its wealth of feeling;

Like perfume from the blossom's cell,

On every zephyr stealing.

Thy mina is like the Strawberry vine,

In all its bright gradations;-

The flowers-its graceful fancies shine,

The fruit-its sweet creations!

I've twined with these a Tulip rich,

Within whose heart of fire,

Thou'lt read a deep, warm passion, which

Can never change or tire! 


\section{DECLARATION OF LOVE.}

TULIP.

Then comes the tulip race, where, beanty plas

Her idle freaks; from family diffused

To family, as flies the father dust,

The varied colours run; and while they break

On the charmed eye, the exulting florist marks,

With secret pride: the wonders of his hand.

THOMSON.

Or the banks of the Bosphorus the tulip is the emblem of 1 constancy; but it is also the symbol of the most violent love. T'he wild tulip is found in the fields of Byzantium, with its crimson petals and golden heart. The petals are compared to fire, and the yellow heart to brimstone; and when presented by an admiring swain to his mistress, it is supposed to declare, that such is the effect of the fair one's beauty, that if he sees her only for a moment, his face will be as fire, and his heart will be reduced to a coal.

The tulip was called tulipan, or turban, from the similarity of its corolla to the superb head-dress of the barbarous Turks, who almost worshipped its elegant stem and the beautiful vaselike flower which surmounts it. They never cease to admire the gorgeous hues of gold and silver, of purple, lilac, and violet, of deep crimson and delicate rose-colour, with every possible variety of teint, which are harmoniously blended together and spread over the rich petals of this splendid member of the court of Flora. The resemblance its shape bears to the turban is thus alluded to in Talla Rookh :-

What triumphs crown the rich divan to-day, With turbaned heads of every hue and race, Bowing before that veiled and awful foce, Like tulip-beds of different shape and dyes, Bending beneath the in risible west wind's sighs. 
Formerly a feast of tulips was celebrated in the seraglio of the Grand Seignior. Long galleries were erected, with raised seats, covered with the richest tapestry, presenting the appearance of an amphitheatre. On these were placed an almost infinite number of crystal vases, filled with the most beautiful tulips the world produced. In the evening the scene was splendidly illuminated; the wax tapers, as they gave light, emitted the most exquisite odours. To these were added lamps of the most brilliant colours, forming on all sides garlands of opal, emeralds, sapphires, diamonds, and rubies. Innumerable singing-birds, in cages of gold, roused by the splendour of the scene, mingled their warbling notes with the melodious harmony of instruments, whose cords were tuned by invisible musicians. Showers of rose-water refreshed the air; and suddenly the doors were opened, and a number of young odalisks entered to blend the brilliancy of their charms and appearance with that of the enchanted scene.

In the centre of the seraglio a splendid pavilion shaded the Grand Seignior, who negligently reclined on costly skins; while the lords of his court, habited in their richest attire, were seated at his feet to behold the dances of the lovely women of the court in all the luxurious display of their light and dazzling dresses. These sometimes encircled, and at others glided round the vases of tulips, whose beauty they sung. It was not seldom that a cloud rested on the sultan's brow; then he looked upon all around with a stern and severe aspect. What! could chagrin then enter the soul of that all-powerful mortal? Had he lost one of his provinces? Did he fear the revolt of his fierce janissaries? Ah no! two poor slaves alone had troubled his heart. He had observed, during the gayetics of the feast, a young page presenting a tulip to a beautiful girl who had captivated him. The sultan was ignorant of their secrets, but a vague feeling of inquietude took possession of his heart - jealousy tormented and beset him. But what is the jealousy of a sultan, or what are bolts and bars, against love? A look and a Hower are enough for that wicked god to change a horrid seraglio into a place of delight, and to avenge beauty outraged by chains. 
'Tulips have had tineir worshippers in other parts of the world beside Turkey. It was from 164 s to 1647 that the tulipomania exercised its influence in Holiar. 1 . In those years tulips fetched enormous prices and enriched many speculators. The most precious kind was that catled semper augustus; this they valued at two thousand florins. They pretended that it was so rare, that there existed only two flowers of that species, one at Haerlem and the other at Amsterdam. A connoisseur, to procure one root, offered four thousand six hundred florins, with a beautiful carriage, horses, and equipments. Another gave twelve acres of land for a tulip-root. We are also told of a person who had a very fine tulip; but finding that there was a second root of the same nature at Haerlem, he repaired thither, and having purchased it at a most extravagant cost, pounded it to pieces with his foot, exclaiming, with exultation, "Now my tulip is unique!"

Yes! by those eyes of azure glory,

Shedding their star-like smiles on me;

Yes! by that cheek, changing and glowing,

Warm as the plumage of yon bright lory,

By those ringlets so richly flowing,

Dearest, I love but thee!

Yes! by that foot of fairy fleetness,

Springing ever so light and free,

By that figure's gazelle-like grace, love,

By thy spirit's pure truth and siveetness,

By all thy magic of mind and face, love,

Ever I love but thee! 
A ND FLOWERS OF POETRY.

DE CEITFUL CHARIIS.

\section{THORN-APPI,E.}

THE flowers of the datura languish beneath their sombre and drooping foliage while the sun shines; but at the approach of night they put forth and are reanimated. Then they display their charms and unfold those immense bell-shaped petals, which Nature has formed of ivory and stained with purple, and to which she has confided a perfume, that attracts and invigorates, but is so dangerous that it produces ebriety and hysterics, even in the open air, on those who respire it.

Heed not her sigh!

'Tis Falsehood's breath:

Trust not her eye !

Belief is death.

A serpent's coil, Thy strength may burst:

No power can foil

Her snares accurst

F. S. 0 .

DEATH WILL REVEAL MY LUVE.

MELILOT.

Tris trefuil, in drying, exhales an agreeable fragrance. Its Aowers are mostly yellow - sometimes white. 
Oh, melancholy Love! amid thy fears,

Thy darkness, thy despair, there runs a vein

Of pleasure, like a smile 'mid many tears -

The pride of sorrow that will not complain -

The exultation that, in after years, The loved one will discover, and in vain, How much the heart, silently in its cell, Did suffer till it broke, yet nothing tell!

\section{I F F I C I, T Y.}

BL A C K-THOKN.

THIs species of plum-tree, from its colour, and from the innumerable thorns which it possesses, has been made the emblem of difficulty. In France they have a proverb to convey the idea of a difficulty, which compares it to a bundle of thorns.

Love, all-defying Love, who sees

No charm in trophies won with ease;-

Whose rarest, dearest fruits of bliss

Are plucked on Danger's precipice!

Bolder than they, who dare not dive

For pearls, but when the sea's at rest,

Love, in the tempest most alive,

Hath ever held that pearl the best,

He finds beneath the stormiest water! 
CLOVE GILLY FLOWER.

THE aromatic clove came originally from the Molucca islanàs ; the inhabitants of those islands wear $\mathrm{jts}$ flowers as a mark of distinction. They say that a chief has two, three, or four cloves, as we say of a distinguished nobleman, that he has many titles, or possesses several honours.

True majesty's the very soul of kings; And rectitude's the soul of majesty.

YoUnG.

DIG I T I I M I S O R T U N.

\section{ROSEBAT.}

Trre Rhododendron maximum, which is reared with care and difficulty as an ornament of European gardens and pleasure-grounds, can be seen in perfection nowhere but in the uncultivated recesses of our own continent. Near the summits of mountains, on the banks of torrents and deep ravines, from which rivers take their rise, where the deep shade, moist soil, and dashing water, preserve the atmosphere in a state of perpetual humidity, these shrubs, in luxuriant size and vigour, are seen to cover tracts of great extent, at one season presenting th unbroken landscape of gorgeous flowers, and at another wîta tneir evergreen foliage forming an impenetrable shelter for : re wild animals of the forest. 
The roble mind, unconscious of a fault, No fortune's frowns can bend, or smiles exalt; Like the firm rock, that in mid-ocean braves The war of whirlwinds and the dash of waves.

ANon.

\section{ISCRETION-SECRECY.}

\section{A I D E N-HIA I R .}

Botanists have in vain sought to find out the nature of this plant, which seems determined to conceal from their learned researches the secret of its flowers and its fruit. It coafides to zephyr alone the invisible germes of its young family. The Creator of all things selects the cradle for her children; and it pleases him sometimes to form a sombre veil with their waving tresses, which ever conceals from vulgar gaze the cave where the solitary naiad sleeps, and where she has slept from the beginning of ages; at other times they are burne on the wings of the wind to the summits of lofty towers, or the tottering remnant of an old chateau, where they shine like verdant stars; and sometimes, disposed in light festoons, they adorn the retired and shady spots which shepherds love. This plant is the prettiest of all ferns; and Pliny states, that, though you plunge it in water, it will still remain dry.

Do anything but love; or, if thou lovest, And art a woman, hide thy love from him Whom thou dost worship: never let him know How dear he is; flit like a bird before him; 
Lead him from tree to tree, from flower to flower; But be not won; or thou wilt, like that bird, When caught and caged, be left to pine neglected, And perish in forgetfulness.

Miss Landon.

\section{I S D A I N.}

\section{YELLOW CARNATION.}

As disdainful people generally exact homage and possess little amiability, so with this plant, it is the least beautiful and fragrant of its kind, yet requires continual care and attention.

Disdain and scorn ride sparkling in her eyes, Misprising what they look on.

SHAKSPEARE.

In the flash of her glances, were passion and pride, In the curve of her lip, there was haughty contempt, As she spoke of the power to riches allied, Of the evil and pain from which she was exempt.

F. S. 0 . 


\section{I S E N S I N N R U P T URE.}

\section{A BROKEN STRAW.}

The custom of breaking a straw, to express tal treaties are broken, may be traced to the first days of monarchy; it may even be said to be of royal origin.

The old chroniclers relate, that in 922, Charıes the Simple, seeing himself abandoned by the principal lords of his court, had the imprudence to convoke an assembly at the Champ-deMai, at Soissons. He sought his friends there, but fi und only a factious cret, whose audacity was increased by his weakness. Some reproached him with indolence; with his prodigalities, and his blind confidence in his minister Haganan; others were angry for the dishonour of his concessions to Raoul, chief of the Normans. Surrounded by their foul sedition, he prayed, promised, and thought to escape by the display of new weaknesses, but in vain. When they saw him without moral courage, their audacity had no bounds; they even declared that he ceased to be their king. At these words, which they pronounced with every sign of violence, accompanied by menaces, they advanced to the foot of the throne, broke some straws which they held in their hands, threw them roughly on the ground, and retired, after expressing by this action that they broke treaty with him.

This example is the most ancient of its kind that we know; but it proves that for a long time this mode of breaking an oath had heen in use, since the vassals did not think it necessary to add a single word of explanation, as they felt sure of being understood.

Alas! how light a cause may move Dissension between hearts that love!

Hearts that the world in vain has tried, And sorrow but more closely tied; 
That stcod the storm when waves were rough,

Yet in a sunny hour fall off

Like ships, that have gone down at sea,

When heaven was all tranquillity!

A something, light as air - a look,

A word unkind or wrongly taken -

Oh! love, that tempests never shook,

A breath, a touch, like this hath shaken

MoORE

The last link is broken,

That bound me to thee; -

The words thou hast spoken

Have rendered me see!

BAYLEY.

D I S G U I S E.

COMIION STRAIIONIUM.

THIs plant is of a very dangerous nature, though it clothes itself with an elegant indented foliage, and garnishes its branches with corollas of a graceful and negligent shape so purely white that it lulls suspicion of its true character to rest. Its charms only allure, that its powerful narcotic poison may more easily destroy. Several instances of its baneful effects upon persons who have endeavoured to chew it are-on record. Only a few years back, a child who had amused herself with this poisonous plant, was so affected as to be in the greatest danger, from which she was rescued only by the prompt assistance of a medival practitionor. 
First I would bid thee cherish Truth,

As leading-star in virtues irain;

Folly may pass, nor tarnis. youth,

But Falsehood leaves a poison-stain.

EIIZA Coor.

Ay! doomed, indeed!- to worse than death;

To teach those sweet lips hourly guile;

To breathe through life but Falsehood's breath, And smile with Falsehood's smile!

F. S. 0 .

Ah! gay to you my srnile may seem: 't is but the lightring brief

That flashes from a darkened soul thruugh gathering clouds of grief.

F. s. 0 .

Though dark the heart that throbs beneath

The cestus in despair; -

What matters it? - the jewel-wreath

Can hide the ruin there!

And oh! though still my diamonds blaze

Above a spirit lonely,

The world - the heartless world - will gaze,

And see my jewels only!

Yes! I would have them deem me blest;

And wealth, at least, may be

A glittering veil for broken rest

Ard endless misery!

F. S 0 . 
AND FLOWERS OF POE

\section{DO ME JUS}

\section{CHISTNUT-TREE.}

Thanks to Benevolus - he spares me yet These chestnuts ranged ì zorresponding lines.

CoWPER.

Chestnuts are enclosed two, three, or four, in une susk or sheil, covered with prickles. Those who are unacquairted with this beautiful tree neglect its fruit in consequence of its rough appearence.

Within the oyster's shell uncouth,

The purest pearl may bide; -

Trust me - you'll find a heart of truth

Beneath that rough outside!

F. S. 0 .

She saw Othello's visage in his mind.

SHAKSpEARE.

\section{U R A B I L I Y .}

CORNELIAN CHERRT-TREE.

A huntress issuing from the wood, Reclining on her cornel-spear she stood.

DRTDEN.

The come-tree does not grow higher than eighteen cr twen:v feet. It ilves for ages, but grows very slowly; it blooms in he spring, and yields its crimson berries in the winter. Thes I. 
are a very handsome fruit, and were formerly made into tarts and robs de cornis. The Greeks have consecrated this tree to Apollo, because it is supposed that that goc presides over the works of the mind, which demand much time and reflection. Charming emblem! teaching every one who wishes to cultivate letters, eloquence, and poetry, that to merit the laurel crown, it is necessary to bear for a long time that of patience and meditation. After Romulus had drawn the plan of Rome on the land which gave him birth, he launched his javelin on Mount Palatine; the shaft of the javelin is said to have been of corneltree; it took root, grew, and became an immense tree; and this prodigy was regarded as the happy presage of the strength and duration of that extraordinary empire.

The wood is very hard, and Evelyn says that when made into wedges it will last like iron.

Lady! my love for thee

Is like the cornel-tree; -

Once taken root, though slow, its growth is sure.

It is no passion-flower,

Lasting one summer-hour; -

While my heart lives - that feeling will endure.

F $\boldsymbol{S}_{1}$, , 
A ND FLOWERS OF POETRY.

\section{LLUSTRATION OF PLATE.}

Primrose.-Honeysuckle.-Marygold.

Be not too early entangled in the chains of Love, or yours will be a life of inquietude.

I would not tell thee for the world, Thy early love will change;

I would not see thy sweet lip, curled In scorn of words so strange.

I would not bid thy smiles away, Nor quell thy speaking blush;

For happy spirits lend the ray, And timid thoughts the flush:

Yet Love is but a dangerous guest,

For hearts so young as thine,

Where Youth's unshadowed joys should rest,

Life's springtime fancies shinè!

Too soon - oh! all too soon - would play

Years hence, that meteor's thrall,

In gloom and glory o'er the way,

Where now but sunbeams fall!

Then, sweetest, leave the wildering dream,

Till Time has nerved thy heart

To brook the fitful cloud and gleam,

Which must in love have part.

Ah ! Life has many a blessed hour,

That Passion never knows;

And Youth may gather many a flower,

Beside the blushing Rose! 


\title{
EARLY YOUTH.
}

\author{
PRIMROSF.
}

No smiling knot

O1 early primroses upon the warm,

Luxuriant, southern bank appears, unmarked By him.

Carrington.

Amid the sunny luxury of grass, Are tufts of pale-eyed primroses, entwined With many a bright-hued flower, and shrub that sicnts The all-voluptuous air.

Carrington.

THE saffron tufts of the primrose announce the return of spring, when we see the snowy mantle of retiring winter ornamented with embroidery of verdure and of flowers. The season of hoar-frost has passed, but the bright days of summer have not yet arrived. The period is emblematical of a lovely girl just passing from childhood to youth. The timid Aglae has scarce attained her fifteenth year, and would fain join the roniping games of her younger companions, but is unable to do so. She watches them, and her heart burns to follow them. But a distaste for innocent joys, which she cannot vanquish, disturbs the heart of this young beauty. An interesting paleness is spread over her face, her heart languishes, and she sighs, scarce knowing why. She has been told that, as spring succeeds to winter, so the pleasures of love follow those of $\mathrm{m}$ fancy. Poor girl! you will learn that those pleasures are mingled with bitterness and tears. The arrival of the primrose announces them to thee to-day, but it also tells thee that the happy period of infancy can never return. Alas! in a few. years you will say, when observing the early primrose, "The " days of love and of youth are fled, never to return." 


\section{In dewy glades,}

Ire peering primrose, like sudden gladness,

G.eams on the soul - yet unregarded fades -

The joy is ours, but all its own the sadness.

H. Coleridge.

This plant has been sung by many of our best poets, but by none so well as he from whose delightful poems we have already quoted at the commencement of this article. The following lines are extracted from a piece addressed to a friend with an early primrose:-

Accept this primrose, friend; it is a pledge

of the returning spring. What though the wind-

The dread east wind - passed over the shivering earth,

And shook from his deep rustling wings the snows,

And bound the streamlets and the rivers all

In cryss: fetters! What though infancy,

And age, and vigorous manhood, felt the blast

Before which many a human blossom fell!

Yet our fine Devon, in a sunny nook,

Cherished this flower; and when the soft west wind

Came with its balmy breath and gentle showers,

With simple grace this firstborn of the year

Waved its pale yellow star; and, lo! for thee

I $\mathrm{pl}$ : cked the welcome stranger.

Sometimes, alas! we see a lady matured in years, whose heauty has been marred by the ravages of time, decking herseli in the gay habiliments of youth; such a one may be compared to the primrose in autumn, whose untimely presence is reproved in the following agreeable sonnet. It is by $R$. F. Housman, and was originally published in the Athenæurr. -

The solitary primrose hath come back

To haunt the green ncrits of her happy spring.

Alas. it is a melancholy thing,

Thus to return, and vainly s:ive to

The playmates of cur youth! Whither have fled

The sweet companions of her vernal honrz?

The bee, the infanit leaves, the golder acter 
That heard the curlsoo's music, as he sped

O'er hill and dale-. whither have they departed?

And the blithe birds - have they too passed away?

All, save the darkling wren, whose plantive lay

Just tells the hermitess is brolin-hearted.

Go, then, pale flower, and hide thy drooping head

For all thy springtime friends are changed, or dead.

I would not waste my spring of youth In idle dalliance. I would plant rich seeds To blossom in my manhood, and bear fruit When I am old.

Hillhouse.

The fresh, buoyant sense of being, That bounds in Youth's yet careless breast, Itself a star, not borrowing light, But in its own glad essence bright.

MOORE.

I saw her first - a petted child, Her eyes were blue as heaven;

Her cheek was dimpled when she smiled;

Her lips - a rosebud riven;

Her form - the prettiest in the world;

Her step - a fairy's flight;

Her hair - like clouds in sunshine - curled

In clusters wild and bright.

"A child," I said;-so artless, wild,

And full of mirth her mien,

You'd deem her but a lovely child,

Though she was just fifteen. 
I wish the sud would never blow!

' $\mathrm{T}$ is prettier and purer so:

It blushes through its bower of green,

And peeps above the mossy screen,

So timidly - I cannot bear

To have it open to the air:

F. S. 0 .

\section{E G O TIS M.}

\section{POET'S NARCISSUS.}

Narcissus fair

As o'er the fabled fountain hanging still.

THOMSON.

THE poet's narcissus exhales a very agreeable perfume; it bears a golden crown in the centre of its pure white petals, which expand quite flat, the stem slightly inclining to one side. The cup or nectary in the centre, which is very short, is frequently bordered with a bright purple circle, and sometimes the nectary is edged with crimson.

Ovid, in his metamorphoses, tells us of the fate of the lovely and coy Narcissus. A thousand nymphs loved the handsorne youth, but suffered the pangs of unrequited love. Viewing himself in the crystal fount he became enamoured of his own image.

Narcissus on the grassy verdure lies;

But while within the crystal fount he tries

To quench his heat, he feels new heats arise.

For, as his own bright image he surveyed,

He fell in love with the fantastic shade;

And o'er the fair resemblance hung unmoved,

Nor knew, fond youth! it was himself he loved.

Ovid. 
In consequence of this error he slighted the lore of Echo, who witnessed his fruitless vows to the deceitful image. Addison thus translates the passage:-

She saw him in his present misery,

Whom, spite of all her wrongs, she grieved to see;

She answered sadly to the lover's moan,

Sighed back his sighs, and groaned to every groan;

"Ah, youth! beloved in vain," Narcissus cries -

"At, youth! beloved in rain," the nymph replies.

"Farewell!" says he; the parting sound scarce fell From his faint lips, but she replied, "Firewell!" Then on the wholesome earth he gasping lies, Till death shuts up those self-admiring eyes. To the cold shades his flitting ghost retires, And in the Stygian waves itself admires.

For him the Nalads and the Dryads mourn; Whom the sad Echo answers in her turn! And now the sister nymphs prepare his urn; When looking for his corpse, they only found A rising stalk with yellow blossoms crowned.

Self is the medium least refined of all, Through which Opinion's searching beam can fall; And, passing there, the clearest steadiest ray Will tinge its light and turn its line astray.

Moore. 


\section{E L E G A N C E.}

\section{ACACIA ROSE.}

ArT has produced nothing that may vie in freshness and in elegance of appearance with this beautiful flowering shrub; its inclining branches - the gayety of its verdure - its clusters of rose-coloured flowers, like bows of ribands, hung on branches, clothed with hairs of a reddish brown, never failed to excite admiration, and have combined to render it a proper emblem of elegance. Its appearance has been compared to that of an elegant female in her balldress.

The world has won her - she has learned

Its measured smile and tread;

The foot that once the snowflake spurned

By courtly rule is led;

And Fashion's hand has smoothed the fold

Of that luxuriant hair,

Where once the tress of glossy gold

Waved wildly on the air.

Her matchless wealth of beauty beggars all Our courtly dames can boast; - her queenly form, Her majesty of mien, would grace a throne.

F. S. 0 .

I shall not soon forget thee, with thy dark and flashing eye, And the pretty little haughty head thou carriest so high; With thy throat, whose swanlike curve is the loveliest I have seen,

And the spirit and the grace of thy merry maiden-mien. 
I shall not soon forget thee, with thy smile's bewildering charm;

With thy snow-white dimpled hand and thy softly rounded arm:

With thy form of fairy moulding, so perfect yet petite; And the light and restless movements of thy dainty little fert.

F. S. 0 .

\section{E L O Q UEN C E.}

W A TER - L IL Y .

calls the lily from her sleep

Prolonged beneath the bordering deep.

WORDSWORTH.

The Egyptians have consecrated to the sun the god of eloquence, the flower of the Nymphæa Lotus. This flower closes at evening, and reclines on the bosom of the lake, from the setting of the sun until the rising of that splendid orb on the succeedirg morn. Flowers of the lotus are inwoven in the head-dress of Osiris. The Indian gods also are frequently represented on the waters as seated on this flower! It is supposed that this allegory may be understood as an allusion to the fiable of the world rising from the midst of the waters.

Expression is the dress of thought.

POPE. 
Thy words had such a melting flow, And spoke of truth so sweetly well, They dropped like heaven's serenest snow, And all was brightness where they fell!

MOORE.

Speech is the morning to the soul: It spreads the beauteous images abroad, Which else are furled and clouded.

DRYDEN AND LEE.

\section{ENCHANTMENT.}

\section{VERVAIN}

She nightshade strows to work him ill, Therewith the vervain and her dill, That hindereth witches of their will.

Drayton.

Ir were well if botanists would attach a moral idea to every plant they describe: we might then have a universal dictionary of the sentiment of flowers - generally understuod - whick would be handed down from age to age, and might be renewed, without changing their characters every succeeding spring.

The altars of Jupiter are overthrown: those ancient forests, that witnessed the mysteries of Druidism, exist no longer; and the pyramids of Egypt shall one day disappear, buried, like the sphinx, in the sands of the desert; but the lotus and the acan thus shall ever flower upon the banks of the Nile, the mistletoe will always flourish upon the oak, and the verrain upon the barren knolls. 
Vervain was used by the ancients for divers hind of divinations; they attributed to it a thousand properties; among others, that of reconciling enemies; and when the Poman heralds-atarms were despatched with a message of peace or war to other nations, they wore a wreath of vervain. Drayton alludes to tmis custom :-

A wreath of rervain heralds wear, Among our garlands named, Baing sent that dreadful news 10 bear, Offensive war proclaimed.

The Druids held this plant in great veneration, and, before gathering it, they made a sacrifice to the earth. Probably they used it for food; and Dryden thus mentions it:-

Some scattering potherbs here and there he found, Which, cultivated with his daily care,

And bruised with rervain, were his daily fare.

We are told that the worshippers of the sun, in performing their services, held branches of vervain in their hands. Venus Victorious wore a crown of myrtle interwoven with vervain, and the Germans to this day give a hat of vervain to the newmarried bride, as putting her under the protection of that goddess. Pliny also tells us that it was made use of by the Druids in casting lots, in drawing omens, and in other magical arts.

Love is the subtlest enchanter, that ever

Wared a wand or muttered a spell;

A magisal rod is each dart in his quiver, The heart's hidden treasures to find and tell.

F. S. 0 . 


\section{ENTERTAIN M E N T-FEASTIN G.}

PARSIET.

PARsLeY was in great reputation among the Greeks. In their banquets they crowned their brows with its light tendrils, which they thought created gayety and so increased their appetites. At Rome, in the Isthmian games, the conquerors were crowned with parsley. It is thought this plant came from Sardinia, because that province is represented on ancient medals under the form of a female, near whom is a vase in which is a bouquet of parsley. But this plant grows in all the fresh and shady places in Greece, and in the southern provinces of France. Guy de la Brosse affirms that it grows also near Paris, on Mount Valerian; but it is presumable that the plant he designates is not the trve parsley, since its introduction into France is attributed to Rabelais, who, according to the learned, brought it from Rome with the Roman lettuce; if this had been the case, he would probablv have attached his name to those modest presents. Rabelais, like Queen Claude, would then have been celebrated by the gourmands of every age. However this may be, the beautiful verdure of this plant forms an elegant garnishing to our dishes; it is the luxury of the soup-kettle; it adds to the delight of the most splendid dinners. A branch of laurel and a crown of parsley are the attributes we admit as belonging to the god of banquets. These plants have served for nobler uses; but in the age of gastronomy, it is unnecessary to recall what was done in the age of heroism.

We may roam through this world like a child at a feast, Who but sips of a sweet, and then flies to the rest; And when pleasure begins to grow dull in the East, We may order our wings and be off to the West; 
But if hearts that feel and eyes that smile,

Are the dearest joys that Heaven supplies, We never need leave our own green isle,

For sensitive hearts and for sunbright eyes.

MoORE.

\section{E N V Y.}

B R A IIB LE.

THE bramble is made the emblem of envy because it interferes $\Xi 0$ much with the growth of other plants.

Oh! she's a monster - made of contradictions !

Let Truth in all her native charms appear, And, with the vorce of harmony itself,

Plead the just cause of innocence traduced;

Deaf as the adder - blind as upstart greatness -

She sees nor hears! And yet let Slander whisper,

Rumour has fewer tongues than she has ears;

And Argus's hundred eyes are dim and slow

To piercing Jealousy's.

LiLLo.

I know that Slander loves a lofty mark;

It saw her soar a flight above her fellows,

And hurled its arrow to her glorious height,

To reach her height and bring her to the ground.

H. MORE. 


\section{E R R O R.}

BEE-OPHR Y S.

THIs plant is singularly beautifu, in its appearance, and its flowers so much resemble the bee, that it is frequently mistaken for one resting on the plant. It commonly grows near woods, and in the open meadows. The most successful method of cultivation is by choosing a soil and situation as natural to them as possible, and by suffering the grass to grow around them.

\section{A spirit pure as hers,}

Is always pure even while it errs As sunshine, broken in the rill, Though turned astray, is sunshine still!

MoORE.

\section{The lover may}

Distrust that look which steals his soul away; The babe may cease to think that it can play With heaven's rainbow; alchymists may doubt The shining gold their crucible gives out;But Faith, fanatic Faith, once. wedded fast To some dear falsehoxd, hugs it to the last.

Mooñ. 


\section{F A R E W L L. \\ MICHAELIIAS DAIST.}

Thus plant begins to put forth its flowers when others are becoming rare, and its, beautiful flowers enliven our gardens as the floral season closes. It seems to be the afterthought of Flora, who smiles on our parterres as she leaves them.

I heard thy low-whispered farewell, love, And silently saw thee depart;Ay, silent; - for how could words tell, love,

The sorrow that swelled in my heart?

They could not - oh! language is faint,

When Passion's devotion would speak;

Light pleasure or pain it may paint,

But with feelings like ours it is weak!

Yet tearless and mute though I stood, love,

Thy last words are thrilling me yet,

And my heart would have breathed, if it could, love, And murmured: "Oh! do not forget!"

F. S. 0 .

\section{F A I S E H O O D}

MI $\triangle N C H I N E E L-T R E E$.

The fruit of this tree is of the colour and size of he golden pippin. Its beautiful appearance has tempted many Europeans to eat of it, who have lost their lives in consequence. 'The tree 
grows to the size of an oak, and its woud is considered very valuable, being capable of high polish, and wearing well. In cutting them down, the juice of the bark is generally burnt out before the work is begun, as it will raise blisters on the skin, and burn holes in linen; and the labourers would be in danger of losing their sight, if it were to fly in to their eyes. Vegetables are said not to grow under its shade, nor cattle to eat of its foliage; except the goat, which may eat it without sustaining injurv.

I turned from the monitor - smiled at the warning, And gave the whole wealth of my soul unto thee;

I heard of thy falsehood - the idle tale scorning, I saw thy brow shadowed, and murmured: "Be free!"

F. S. 0 .

- If eyes like thine can falsely shine,

I 'll cease to look for truth on earth;

If lips so sweet can breathe deceit,

Ne'er trust I more to woman's worth.

E. S. O.

\section{FIDELITY IN A D ERSITY.}

\section{ALL-FLOWER.}

The rude stone fence with wall-flowers gay,

To me more pleasure yields,

Than all the pomp imperial domes display.

Scotr.

THIs favourite flower of the cottage-garden loves to grow in the crevices of old walls; to flourish in those of ruined towers, 
or ornament the mouldering tablet which records the names of those now almost forgotten by surviving relatives.

\section{For this obedient zephyrs bear \\ Her light seeds round yon turret's mould, And, undispersed by tempest, there \\ They rise in regetable gold.}

LANGHIRNE.

Not seldom do we observe a solitary wall-flower growing in the falling towers of an ancient castle, where it seems to race itself to conceal the unheeded injuries which the barbarians of feudal ages had recklessly dune to the battlemented pile. Scott says:-

And well the lonely infant knew

Recesses where the wall-flower grew,

And honeysuckle loved to crawl

Up the low crag and ruined wall.

I deemed such nooks the sweetest shade

The sun in all his round surveyed.

We are told that the minstrels and troubadours of former days carried a branch of wall-flower as the emblem of an affection which continues through all the vicissitudes of time, and survives every misfortune.

During the reign of terror in France, the violent populace precipitated themselves toward the abbey of St. Denis, to disinter the ashes of their kings and scatter them to the winds. 'The barbarians, after breaking open the sacred tombs, were affrighted at the sacrilege, and went and hid their spoil in an obscure corner oehind the choir of the church, where they were forgotten amid the horrors of the revolution. The poet, Trenuel, some time after visited the spot, and found the sculptured fragments covered with the wall-Hower. 'This plant, faithlul in misfortune, diffused sweet perfumes in that religous receptacle, which might be likened to an offering of incense 
AND FLOWERS OF POETRY.

ascending toward heaven. This scene produced the following lines from the inspired poet's pen:-

Mais quelle est cette fleur que son instinct pieux

Sur l aîle du zéphyr amène dans ces lieux?

Quoi! tu quittes le temple ô̂ vivent tes racines,

Sensible giroflée, amante des ruines,

Et ton tribut fidèle accompagne nos rois?

Ah! poisque la terreur a courbé sous ses lois

$\mathrm{Du}$ lis infortuné la tige souveraine,

Que nos jardins en deuil te choisissent pour reine;

Triomphe sans rivale, et que ta sainte fleur

Croisse pour le tombeau, le trône, et le malheur.

There is a mystic thread of life,

So dearly wreathed with mine alone,

That Destiny's relentless knife

At once must sever both or none!

Byron.

Oh! what was love made for, if ' $t$ is not the same, Through joy and through sorrow - through glory and shame?

Moore.

\section{FA NCY'S FIRE.}

NIGHT-RLOWING CEREUS.

Tirs stately flower is found in different parts of South America, and in some of the $\mathrm{W}$ est India islands. It expands a most beautiful corolla of nearly a foot in diameter. The inside of the calyx is a splendid ye.low or bright sulphur colour; the petals of the purest white; but viewing it in front, so as to 
look into its deep bell, whence issue its long, trembling stamina, baffles all description; for in one shade, it is of an aurora colour; viewed in another, it resembles the blaze of burning nitre; and as the eye plays over it, we think we see, at times, a briliant purple." - "This grand flower opens its beautiful corol, and diffuses a most fragrant odour for a few hours in the night, then closes to expand no more."

O'er a blossom of Thought gay Fancy plays, And lights, with her smile, its leaves;

Till they gleam with a myriad teinted rays,

As the sun, in a diamond, weaves

His braid of resplendent rainbow bloom,

That changes and glows, like a fairy's plume.

\section{FASCINATION.}

CIRCEA, OR, ENCHANTER'S NIGHTSHADE.

Thrice round the grave Circæa prints her tread, And chants the numbers which disturb the dead.

DARWIX.

As the name of this plant indicates, it is celebrated in magical incantations. Its flowers are rose-coloured, and veined with purple; and commonly grow in damp and shady places, where shrubs fit for the purpose to which this has been applied may be supposed to be found. It is zamed Circæa after the enchantress Circe. 
A ND FLOWERS OF POETRY.

You'll speed your conquering way I trow, Through hearts, however narrow; Those lips are Cupid's graceful bow, That smile his sunlit arrow;

F. S. 0 .

\section{FEIICITY.}

SWEET SOLTAN.

ThIs sweet-scented species of centaury was introduced into England in the reign of Charles I. It is mentioned by Parkinson, in 1629 - " as a kinde of these corne-flowers, I must needs adjoyn another stranger of much beauty, and but lately obtained from Constantinople, where because, as it is said, that the great Turk, as we call him, saw it abroad, liked it, and wore it himself, all his vassals had it in great regurd, and hath been obtained from them by some that have sent it into these parts." And he adds, "the Turks themselves do call it the sultan's flower, and I have done so likewise, that it may be distinguisiled from all the other kindes." It is also very commonly called Blackamoor's Beauty. We are told that, in the East, it made the emblem of supreme happiness.

The spider's most attenuated thread

Is cord, is cable, to man's tender tie

On earthly bliss; - it breaks at every breeze.

YOUNG.

There's a bliss beyond all that the minstrel has told, When two that are linked in one heavenly tie, 
With heart never changing, and brow never cold, Love on through all ills, and love on till they die,

MOORE.

\section{FIRSTEMOTION DF LOVE.}

\section{I I A C.}

THE lilac is consecrated to the first emotion of love, because nothing is more delightful than the sensations it produces on its first appearance on the return of spring. The freshness of its verdure, the pliancy of its tender branches, the abundance of its flowers - their beauty, though brief and transient - their delicate and varied colours; all their qualities summon up those sweet emotions which enrich beauty, and impart to youth a grace divine. Anacreon has heautifully expressed this idea in the following lines:-

In flying blushes richly play;

\section{Beauty's rosy ray}

Blushes of that celestial flame

Which lights the cheeks of rirgin shame.

Albano was unable to blend, upon the palette which love had confided to him, colours sufficiently soft and delicate to convey the peculiarly beautiful teints which adorn the human face in early youth;

\section{The ra.ret down that spreads the cheek;}

Van Spaendock himself laid down his pencil in despair before a bunch of lilac. Nature seems to have aimed to produce massy bunches of these flowers, every part of which should astonish by its delicacy and its varicty. The gradation of colour, from the purple bud to the almost colourless flowers, is the least charm of these beautiful groups, around which the 


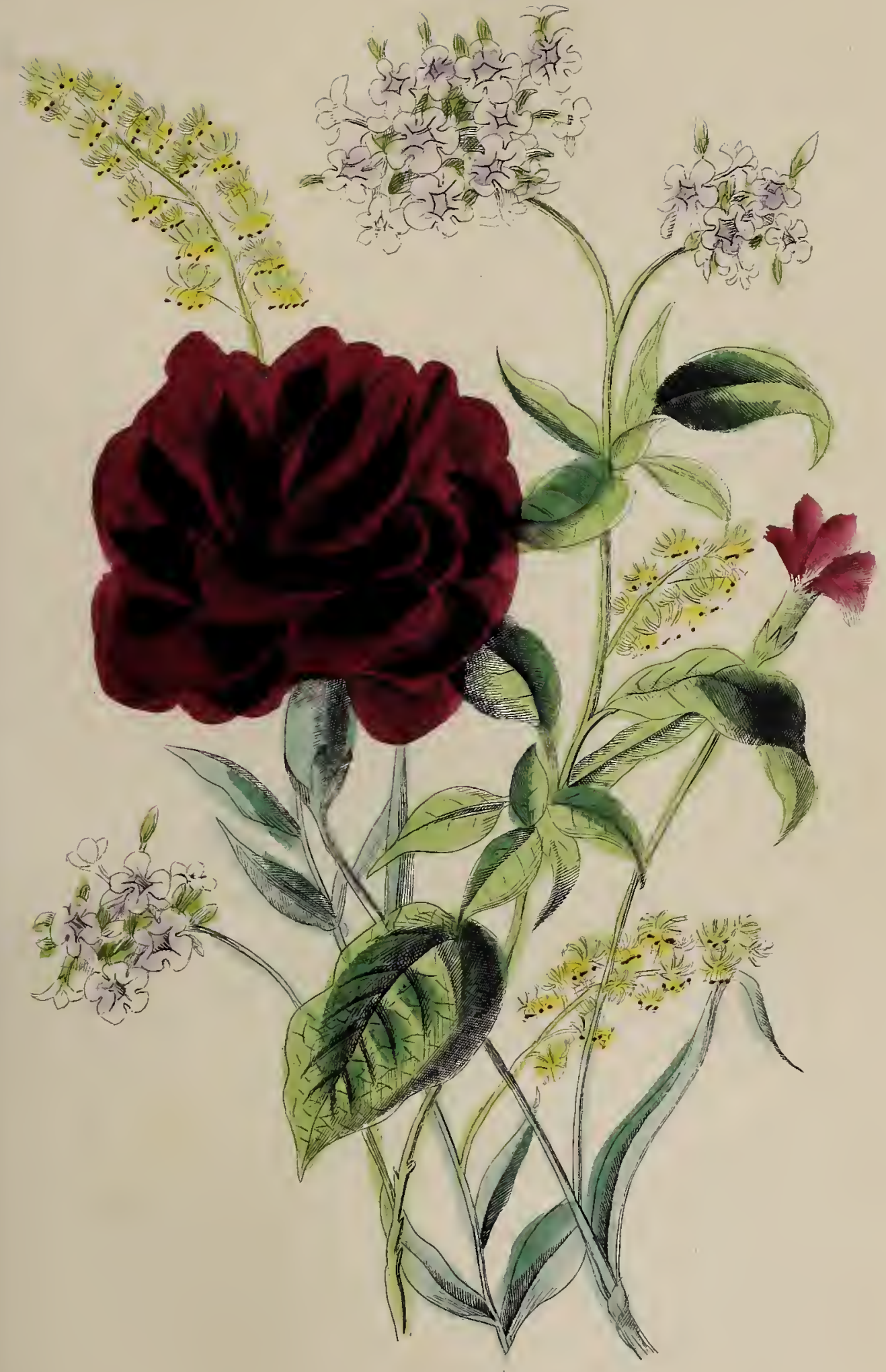



iight plays and produces a thousand shades, which, all blending together in the same teint, forms that matchless harmony which the painter despairs to imitate, and the most indifferent observer delights to behold. What labour has Nature bestowed to create this fragile shrub, which seems only given for the gratification of the senses! What a union of perfume, of freshness, of grace, and of delicacy! What variety in detail! What heauty as a whole!

There, on the banks of that bight river born, The flowers that hung above its wave at morn, Blest not the waters as they murmured by: With holier 'scent and lustre, than the sigh And virgin glance of first affection cast, Upon their youth's smooth current as it past.

MOORE.

\section{F L A M E.}

XELLOW-IRIS.

A mid its waving swords, in flaming gold The iris towers.

C. SMith.

The Iris Germanica are rustic plants, which the German peasants love to grow on the tops of their cottages. When these beautiful flowers are agitated by the breeze, and the sun gilds their petals, teinting them with hues of gold, purple, and azure, they have the appearance of light and perfumed Hames, glistening over the rustic $d$ wellings. This appearance has gained the flower the name of "Flaming Iris." 
The German peasant wreathes his roof with flower in rich attire,

For sun-tressed Iris waves for him her urns of fragrant fire: But we have let a holier gem our lowly home illume;The flower of love our lattice ights with undecaying blnom.

F. S. 0 .

\section{F L A T T R Y. \\ VENUS'S LOOKING-GLASS.}

As soon as the sun shedsitsgolden light upon our cornfields, we see shining in the midst, the bright purple corollas of the starry flowers of this pretty species of campanula, which, from its resemblance to a mirror, has been named Venus's lookingglass. If the sun's rays be intercepted by clouds, these beautiful flowers immediately close, as at the approach of night. There is an ancient fable which tells us that Venus accidentalIy let one of her mirrors fall on the earth. A shepherd found it, and casting his eyes upon the glass, which had the power of adorning the object it reflected, he forgot his mistress, and had no other wish than to admire himself. Love, who feared the consequences of so foolish an error, broke the glass, and transformed the remains into this pretty plant.

Beautiful? yes! Those deep-blue eyes

On heaven have gazed, till they caught its dyes;

Thou hast been seeking the rose, to sip

ts dewy bloom for thy balmy lip;

Thou hast been out in the radiant air,

Wooing the sun fith thy wary hair; 
For a rich gleam breaks through its braids of brown, Like a smile from Day's bright Eye sent down;

Beautiful? yes! but the rose will fade;

The smile grow dım which the bright eyes wear;

The gloss will vanish from curl and braid, And the sunbeam die in the drooping hair!

Turn from the mirror! and strive to win

Treasures of loveliness still to last;

Gather earth's glory and bloom within!

They will be thine when youth is past.

A would-be belle once broke her glass,

For reflecting a loveless frown she wore;

And you are breaking my heart, sweet lass,

For telling you truth, like the mirror of yore!

F. S. 0 .

\section{F LA T TERY'S SMILE.}

\section{BUCKBEAN.}

Br that lake whose silvery waters reflect the cloudless sky, du you see those clusters of flowers, white as the drifted snow? The underside of those beautiful flowers is lightly tinged with a rosy hue; and a tuft of filaments of great delicacy and of dazzling whiteness, springs from each alabaster cup. Language will not convey a just idea of the elegance of this plant; but, if once seen waving gently over the water's brink, whose transparency and freshness it seems to increase, it will never be forgotten. The flowers of the buckbean never open in stormy 
weath s:, but bloom only in calm and sunshine; and the calm which : $t$ enjoys seems to be imparted to every object around it.

There's danger in the dazzling eye,

That woos thee with its witching smile;

Another, when thou art not by,

Those beaming looks rould fain beguile.

F. S. 0 .

\section{FLY WITH ME.}

\section{VENUS'S CAR.}

This graceful flower, as its name implies, resembles an elegant chariot, drawn by a pair of doves, which are hidden in a part of the corolla, and fly out when it is pulled down by the the hand. The colour of the flower is usually a deep blue.

Gay Zephyr bore to my feet, last night, This curved and carved barouche of blue;

I thought it, at first, a flower in flight: And so it will seem, perhaps, to you.

But press on the foremost petal, sweet, That rose-teinted finger, soft and light, And two young doves your touch will meet, And spring from their couch to your startled sight

Gay Zephyr a secret whispered low, When with the gift to rny feet he flew;- 
It may be a fable - I thought it so:

And so it will seem, perhaps, to you.

But he said the queen of fairy-land -

T'he elfin Venus, wild and bright,

With a wave of her tiny, star-tipped wand,

Could charm these delicate doves to flight!

At play in her firefly-lighted bower,

He had heard her order her blooming car;

And she smiled, as she soared in the azure flower,

As smiles, in yon blue heaven, a star!

Oh! could I only summon her here,

And bid her bewitch the birds once more!

How fit a phæton this, my dear,

To waft us lovers the wild wave o'er!

You should be queen of a fairy realm!

There's a trifling fault in the vehicle - true:

lt is rather too small for both, my gem:

And so it will seem, I fear, to you!

F. S. 0 .

\section{FOLLO W IIE.}

STAR OF BETHLFHEM.

THE star-like flowers of this plant are common among the grass in our pastures. 
Dost thou not see in Fancy's eye

A bird with wings of emerald light, That soars, for ever, far on higt And, as it rises, beams more bright? What sings its plaintive voice to thee? "Follow, follow, follow me!"

The bird is Hope! 't would lead the soul, With its sweet tones and seraph-bloom, From worldly woes - from earth's control: 'T will fold in heaven its shining plume! Up! up! thy spirit's pinions try! Oh! keep that brilliant warbler nigh!

Dost thou not see in Fancy's eye A soft, a pure, undazzling star, That seems to melt in yonder sky, Yet still keeps smiling on afar? What speaks its eloquen smile to thee? "Follow, fo!low, follow me!"

The star is Love-celestial Love!

'T would woo from bowers of bliss below, To those where broods the deathless dove,

With beaming wing and breast of snow!

Oh! let thy soul's affections twine, For sve, $w^{*}$ h that light divine! 


\section{F OLL Y. \\ COLUAIBINE.}

Bring hither the pincke and purple cullambine.

SPENSER.

This is Folly, Childhood's guide.

This is Childhood at her side.

HAWKESWORTII

Tins graceful flower has long been a favourite inhabitant of the rustic flower-border, and is commonly found in the open places of forests, or extensive woods. Why it has been made the emblem of folly it is difficult to say, some affirming that it is on account of the shape of its nectary, which turns over in a similar manner to the caps of the ancient jesters; while others suppose it to be on account of the party-colours which it generally assumes.

Folly of old, with gay deceit,

When Love was seeking Virtue's bower,

Led the bright boy to Beauty's feet;

And she, in that one fatal hour,

Enwove a chain so strong, so fair,

It bound them both for ever there!

F. S. 0 .

\section{F O R E I G H T.}

HOLLY.

THE providence of an all-wise Creator is shown in an admirable manner in this beautiful plant. The great hollies which 
grow in the forest of Needwood bear leaves bristling with thorns to the height of eight or ten feet, and above this height the leaves cease to be thorny. There the plant has no need to arm itself against enemies which cannot reach it. This tree, with its dazzling verdure, is the last ornament of our forests, when they are despoiled by the winter's frosts and chilling blasts; its berries serve as food for the little birds which remain with us through the inclement season of winter; and it also offers them a comfortable shelter amid its foliage.

In that delightful work, "Jesse's Gleanirgs in Natural History," the eloquent author, speaking of the holly, says: "The economy of trees, plants, and vegetables, is a curious subject of inquiry, and in all of them we may trace the hand of a beneficent Creator. The same care which he has bestowed on his creatures is extended to plants; this is remarkabiy the case with respect to hollies; the edges of the leaves are provided with strong sharp spines, as high up as they are within the reach of cattle; above that height the leaves are generally smooth, the protecting spines being no longer necessary."

$O$ reader! hast thou ever stood to see

The holly-tree?

The eye that contemplates it well perceives

Its glossy leaves;

Ordered by an Intelligence so wise

As might confound an atheist's sophistries.

Below a circling fence, its leaves are seen,

Wrinkled and keen;

No grazing cattle through their prickly round

Can reach to wound;

Ent, as they grow where nothing is to fear,

Emooth and unarmed the pointless leaves appear.

Southey. 
AND FLOWERS OF POE'TRY.

\title{
ILLUSTRATION OF PLATE.
}

\author{
Forget-me-not. - Cypress. - Pimpernel.
}

Forget me not, for, alas! we may never meet again.

ONE kiss for thy brow, love -

One sigh to the past -

One heart-echoed vow, love-

The fondest and last!-

For the true and warm-hearted

In anguish must sever;

It is o'er - we are parted,

Henceforth and for ever!

Yet as Night's scented flower,

Shunning Sunlight's caresses,

Gives the hallowed star-hour

All the wealth it possesses,

So to thee, in thy sadness,

Through darkness and doubt, My soul all its madness

of love shall breathe out.

And thou - wilt thou cherish

My memory yet?

Yes, yes, though we perish,

We cannot forget!

Ah! doomed, broken-hearted,

In anguish to sever!

It is done-we are parted,

Henceforth and for ever! 


\section{F O R G E T - M E - NOT.}

\section{MIYOSOTIS, OR MIOUSE-EAR.}

Nowhere are the beautiful flowers of this plant found in such great abundance, as on the banks of a brook near the Luxumbourg. The peasants call that brook the "Fairy Bath," or the "Cascade of the enchanted Oak." These two names are given to it on account of the beauty of its source, whence it issues murmuring at the foot of a very old oak. The waters of the brook at first roll on from cascade to cascade, under a long vault of verdure, and afterward flow gently through an extensive meadow; then they appear to the enchanted eye as a long silver thread. The southern bank alone is covered with a thick tapestry of mouse-ear; its pretty flowers sparkle in July, clad in as bright a blue as that of the cerulean sky. Then they incline as if they took delight in admiring themselves in tine crystal waters, whose purity is unequalled. On this spot the young girls frequently assemble to celebrate their birthdays by dancing on the borders of the brook. When crowned with these lovely flowers, we might suppose them to be nymphs celebrating games in honour of the naiad of the enchanted oak.

It is related that a young couple, who were on the eve of being united, while walking along the delightful banks of the Danube, saw one of these lovely flowers floating on the waves, which seemed ready to carry it away. The affianced bride admired the beauty of the flower, and regretted its fatal destiny. The lover was induced to precipitate himself into the water, where he had no sooner seized the flower than he sank into the flood; but making a last effort, he threw the flower upon the shore, and at the moment of disappearing for ever, he exclaimed, "Vergils mich nicht," since which time this flower has been marle emblematical, and taken the name of "Forget-me-not." 
AND FLOWERS OF POE'RY.

Lay to thy heart this token-Hower!

With Love's own tears its leaves are wet.

'T will whisper, in its dying ho"is,

"Do not forget"

F. S. 0 ,

\section{F O R S K E N.}

GARDEN ANEMIONE.

The coy anemone, that ne'er uncloses

Her lips until they're blown on by the wind.

H. Smitif.

Anenione was a nymph beloved by Zephyr. Flora, being jealous, banished her from her court, and changed her into a flower, which always opens at the return of spring. Zephyr has abandoned this unfortunate beauty to the rude caresses of Boreas, who unable to gain her love, agitates her until her blossoms are half open, and then causes her immediately to fade.

Go, deceiver, go!

Some day, perhaps, thou'lt waken

From pleasure's diream, to know

The grief of hearts forsaken!

Moore. 


\section{F R I E N D S H I P}

\section{IV $\mathrm{Y}$.}

I lore the ivy-mantled tower, Bocked by the storms of thousand years.

CUNmixgha.

Friendship has chosen for its device an ivy which clothes a fallen tree, with these words: "Rien ne peut m'en détacher." In Greece, the altar of Hymen was surrounded with ivy, a sprig of which was presented by the priest to a new-married spouse, as the symbol of an indissoluble knot. The Bacchantes, old Silenus, and Bacchus himself, were crowned with ivy. The author of a French work says: "Nothing is able to separate the ivy from the tree around which it has once entwined itself; it clothes the object with its own foliage in that inclement season when its black boughs are covered with hoar-frost; the companion of its destinies, it falls when the tree is cut lown. Death itself does not detach it, but it continues to decorate with its constant verdure the dry trunk it had chosen as its support."

It is a popular error that the ivy is a parasitical plant, deriving its support from the tree which it environs, when in fact it is sustained by its own vital powers; its rocts are fixed in the earth, and the sap is conveyed into its branches by the same laws which regulate the vital functions of other members of the vegetable kingdom.

Thou art a friend indeed,

Most truly true and kind;

Thou givest me, in my spirit-need,

Thy wealth of heart and mind! 


\section{G R I E F.}

H Y A I NTH.

According to mythologists, this flower sprang from the blood of Hyacinthus, who was killed by a quoit, through the agency of Zephyr, who blew it from its course as it passed from the hand of Apollo, and smote the unfortunate youth on the head. Hurd mentions

The melancholy hyacinth that weeps

All night, and never lifts an cye all day;

probabiy in allusion to the melancholy fate of Hyacinthis.

The following address to the hyacinth is extracted from Tait's Magazine. The lines were sent to the editor of that talented periodical as the production of a young country-girl in the north of Ireland. We agree with him in saying (if that statement be true) that they are indeed more than wonderful. They are introduced here with great propriety, as they refer to the fate of Hyacinthus, as detailed in the preceding paragraph.

Oh! mournful, graceful, sapphire-1oloured flower, That keepst thine eye for ever fixed on earth!

Gentle and sad, a foe thou seemst to mirth -

What secret sorrow makes thee thus to lower?

Perhaps 't is that thy place thou camnot change, And thou art pining at thy prisoned lot;

But oh! where couldst thou find a sweeter spot,

Wert thou permitted earth's wide bounds to range?

In pensive grove, meet temple tur thy lorm, Where, with her silvery music, doth intrude The lucid stream, where naught unkind or rude

Durst break of harmony the hallowed charm. 
Thy beauties, all unseen by vulgar eyos,

Sol, in his brightness, still delights to view,

He clothes thy petals in his glorious hue,

To show how much of old he did thee prize.

fnd what the sighing zephyr hither brings,

To wander in these muse-beloved dells -

It is to linger midst thy drooping bells,

While vain repentance in thine ear he sings.

And, sweetest fow er, methinks thou hast forgiven

Him who unconsciously did cause thy death;

For, soon as thou hadst yielded up thy breath,

IVith grief for thee his frantic soul was riven.

And thou wert placed where rningle wave and breeze

'Their dreamy music with the vocal choir,

Whose rarled harmonies might seem a lyre,

Striving with dying notes thy soul to please-.

Where winter ne'er ungraciously presumes

To touch thee with his sacrilegious hand-

Where thy meek handmaids are the dews so bland-

Where spring around thee spreads her choicest blooms.

' $T$ is not revenge nor pining wretchedness,

Thy head in pensive attitude that throws -

' $T$ is extreme sensibility', that shows

In gesture gratitude speech can 't express.

E'en while I pay this tributary praise,

Methinks a deeper tinge thy cheek doth flush; I

What, lovely one, need make thee thus to blush,

And turn away from my enraptured gaze?

No, gentle ryacinth, thou canst not grieve,

When this:ss so lovely worship in thy train -

The sun, the wind, the wave - ch! it were vain

To sum the homage which thou dost receive.

The sad and musing poetess you cheer -

At sight of thee Mem'ry's electric wings

Waft to her soul long, long-forgot'en things-

Loved roices hushed in death she so ns to hear. 
AND FLOWERS OF POETRY.

They said her cheek of youth was beautiful, Till withering sorrow blanched the white rose there. Matiurin.

The withered frame, the ruined mind, The wreck by passion left behind, A shrivelled scroll, a scattered leaf, Seared by the autumn blast of grief!

BYRON.

No words suffice the suffering soul to show; For Truth denies all eloquence to $\mathrm{Wo}_{0}$ !

Brron.

\section{GE NER O S I TY.}

\section{OR A N GE-TREE.}

THIs is a very ancient genus, and combines many excellences in its species; it is a handsome evergreen; it has most odoriferous flowers, and brilliant, fragrant, and delicious fruits. Loudon observes, that "it is one of the most striking of fruitbearing trees, and must have attracted the notice of aboriginal man long before other fruits of less brilliancy, but of more nutriment or flavour. The golden apples of the heathens, and forbilden fruit of the Jews, are supposed to allude to this farnily, though it is remarkable that we have no authentic records of any species of citrus having been known to, certainly none were cultivated by, the Romans." In the latter part of the seventeenth century, it was a very fashionable tree in conservatories; where few exotics of other sorts were at that time to 
be found. It has been likened to a generous friend, who is ever loading us with favours.

The truly generous still deny themselves, with cheerful pride, That, when a suffering brother pleads, he need not be denied!

F. S. 0 .

\section{G L O R Y.}

LAUREL.

THE Greeks and Romans consecrated crowns of lacirel to glory of every kind. With them they adorned the brows of warriors and of poets, of orators and philosophers, of the vestal virgin and the emperor.

This beautiful shrub is found in abundance in the island of Delphos, where it grew naturally on the banks of the river Peneus. There its aromatic and evergreen foliage is borne up by its aspiring branches to the height of the loftiest trees; and it is alleged that by a secret and peculiar power they avert the thunderbolt from the shores they beautify. The beautiful Daphne was the daughter of the river Peneus. She was beloved by Apollo; but, preferring virtue to the love of the most eloquent of gods, she fled, fearing that the eloquence of his speech should lead her from the paths of virtue. Apollo pursued her; and as he caught her, the nymph invoked the aid of her father, and was changed in to the laurel.

In our free land, where letters are so extensively eultivated, they who succeed in exciting popular favour meet with more remuneration than in ancient days; but how few have been honoured so highly as their merits demand, until the last debt of nature has been paid, and then the marble bust, wreathed 
with bay, is raised to immortalize his fame, when his ears are become deaf to praise. He seldom receives his honours une while he enjoys the beauties of this terrestrial globe; and Csare has said, in his "Address to a Poet" -

The bard his glory ne'er receives,

Where summer's common flowers are seen,

But winter finds it, when she leaves

The laurel only green;

And Time, from that eternal tree,

Shall weave a wreath to honour thee.

\section{Real glory}

Springs from the silent conquest of ourselves.

THonson.

Glory is like a circle in the water, Which never ceaseth to enlarge itself, Till, by broad spreading, it disperse to nought.

SHAKSPEARE.

\section{G R A C E S.}

\section{HUNDRED-LEAVED ROSE.}

This tree bears a very fine double flower, of a deep crimson colour; its perfume, however, is weak.

It is mentioned by Pliny as growing around Campania, in Italy, and in the neighbourhood of Philippi, in Greece; and its flowers are so double that they have a hundred leaves. This rose does not, however, grow there naturally, but near to Mount Pangæus, and when transplanted thence to Philippi, they yield finer Howers than on their native mountain. It is recorded that, 
when the Graces accompany Venus and her ministering Cupids, they are crowned with myrtle; and when they follow the $\mathrm{Mu}$ ses, they are crowned with wreaths of the hundred-leaved rose.

Gifted and worshipped one! genius and grace Play in each motion and beam in thy face.

F. S. 0 .

So light - that, gazing breathless there,

Lest the celestial dream should go,

You'd think the music in the air

Waved the fair vision to and fro!

Or that the melody's sweet flow

Within the radiant creature played;

And those soft wreathing arms of snow

And white sylph-feet, the music made!

Now gliding slow, with dreamy grace,

Her eyes beneath their lashes lost Now motionless, with lifted face,

And small hands on her bosom crossed-

And now, with flashing eyes, she springs, -

Her whole bright figure raised in air,

As if her soul had spread its wings,

And poised her one wild instant there!

F. S. 0 . 


\section{GR A N D E U R.}

A. SH.

The towering ash is fairest in the woods.

VIRGIL.

ThERE is a singular allegory in the Edda, which states that the gods hold their court under the shade of a miraculous ash, whose extensive branches shadow the whole surface of the earth; the top of the tree touches the heavens, and its roots descend to the regions of Pluto. An eagle constantly reposes on the tree, to observe everything, and a squirrel continually ascends and descends to make report. Beneath its roots flow two fountains. In the one wisdom is concealed, and in the other is found the knowledge of things to come. Three virgins are intrusted with the charge of this sacred tree, who ever remain under its branches to refresh the tree with these salutary waters, which, on falling back on the earth, form a dew that produces honey. This effect has been ingeniously compared to the results of inventive science.

Still, in the vast and the minute we see The unambiguous footsteps of the God, -Who gives its lustre to an insect's wing, And wheels his throne upon the rolling worlds.

CoWPER. 


\section{H A U G H T I N E S S-P R I DE.}

$\triangle M$ M PLIIS.

GARDENERS say that the amaryllis, of which there are numerous varieties, is a proud plant, because it frequently refuses its flowers to their most earnest cares. The Guernsey lily is a charming flower, and closely resembles the tube-rose in appearance and size; it is of a cherry-red colour, and, when the sun shines upon it, it seems studded with gems of gold. The name of this plant is derived from a Greek word, which has been not inappropriately translated by Monsieur Pirolle, as significant of splendour, and perhaps we have no flowering plant more beautifully gay than the amaryllis.

Alas! for the gay, who, in gorgeous array, And chariots of pride, to God's altars are rolled! They would turn from a love-breathing seraph away, If he came not apparelled in purple and gold.

F. S. 0 .

HAVE I CAUGHT YOU AT LAST? VENUS'S FITTRAP.

THE leaves of this singular plant expand to the light, and are remarkably sensible to the touch of any extraneous body: thus, by suddenly folding, they often enclose insects or the smaller leaves of neighbouring plants. 
Have I caught you at last, gentle rover?

Do I see you at length at my feet?

Will you own yourself, sighing, my lover?

This triumph is sudden as sweet!

Long vainly I strove to allure him;

That tender endeavour is past;

My task must be now, to endure him!

Heighho! but I've caught him at last!

F. S. 0 .

\section{HE A L I N G. \\ BALAI OF GILEAD.}

This exquisite balm was justly esteemed by the ancients, and seems to have been prepared by nature to soften our pains. We often employ the word balm in a moral sense, to express that which tempers and sooths our sorrows. Bexeficent virtue and tender friendship are true balms which heal the wounds of the heart-wounds a thousand times more insupportable than all plyysical ills.

And when my heart would gush with feeling

To catch one kind, one sunny look,

When love would be a leaf of healing,

But scorn a thing I will not brook-

Oh! it is hard to put the heart

Alone and desolate away,

To curl the lip in pride, and part

With the kind thoughts of yesterday.

WILLIS. 
HEARTLESS BEAUTY.

DAHIIA.

THE gorgeous flowers of the dahlia allure only to disoppoint us, for they are without fragrance.

The light, the grace, the brilliant bloom, Of Beauty, unendowed with heart, Resemble flowers without perfume, And just as little joy impart.

F. S. 0 .

H O P E.

HATTHORN.

Now hawthorns blossom, now the daisies spring.

POPE

THE haw thorn has been made the emblem of hope, because the young and beautiful Athenian maids brought its branches, covered with flowers, to decorate their companions on their nuptial day, while they bare larger boughs of it to the altar. 'Tne altar of Hymen was lighted by torches made from the wood of this tree; and it also formed the flambeaux which illuminated the nuptial chamber. We are told that the Troglodytes in the simplicity of their minds, tied hawthorn branches to the dead bodies of their parents and friends; and at the interment of the corpse they strewed its branches upon the body, and afterward corered it with stones, laughing through the whole of the 
ceremony. They considered death as the dawning of a life which should never cease.

Gives not the hawthorn-bush a sweeter shade

To shepherds, looking on their silly sheep,

Than doth a rich embroidered canopy

To kings, that fear their subjects' treachery?

Oh! yes, it doth; a thousand-fold it doth.

Fair Hope, with light and buoyant form,

Came smiling through the clouds of Care, Glanced bright defiance on the storm,

And hung her bow of promise there.

F. S. 0 .

\section{H Y F O C R I S Y.}

\section{EBONY .}

Putro, god of the infernal regions, was seated uprn a throne of eoony. We say of one notoriously wicked, that " he has a heart as black as ebony." This proverb originated in the circumstance of the aubier of the ebony-tree being white, its foliage soft and silvery, its flowers brilliant and beautiful, while the heart only of the tree is black.

Hypocrisy, the only evil that walks

Invisible, except to God alone,

By his permissive will through heaven and earth.

MILToN. 
Her brow is white as stainless snow,

As ebon, black, her heart of sin-

Her cheek with morning's blush doth glow

O'er midnight gloom within!

F. S. 0 .

\section{HOW CA M E Y U HERE?}

IFALKING LEAF.

This is a curious fern, striking root at the extremity of the frond or leaf, from which root new plants arise. It is found in rocky woods.

You know mamma, can't bear you, love,

You know papa dislikes you, dear;

You know my brothers cut you, dove; -

Alas! how came you here?

You know your fortune's gone, my own!

You know your coat was made last year; -

I never ramble now alone; -

What could have sent you here?

Perhaps you do not know, my sweet -

Sir John will soon propose - I fear!

How very awkward, should you meet!

What nonsense brought you here? 


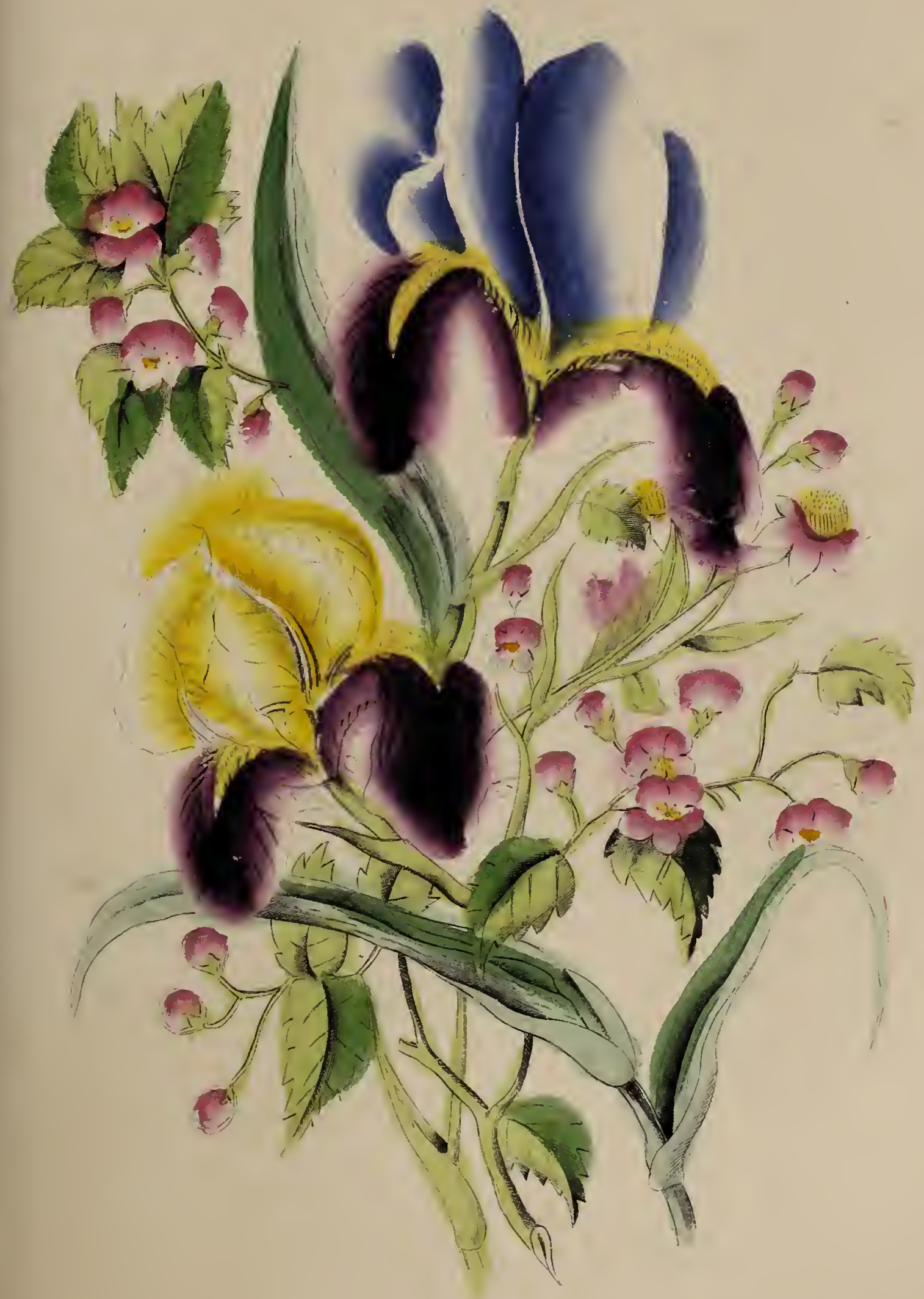



AND FLOWERS OF POETRY.

I vow I'm quite afraid to stir,

Lest you are in the way or near!

I needs must say I wish you, sir!-

Oh! anywhere but here!

F. S. 0 .

\section{A T TACH M Y ELF TO YOU.}

SCARLET IPONEA, OR INDIAN JASAINE.

THIs beautiful twining plant is a species of blindweed, or something analogous; like the convolvolus, it requires something to support its light tendrils; and, without fatiguing that support, wreaths it with verdure and flowers.

To cheer thy sickness, watch thy health -

Partake, but never waste thy wealth -

Or stand with smiles unmurmuring by,

And lighten half thy poverty!

BYron.

Jasmine, some like silver spray,

Some like gold, in the morning ray.

INDIAN BRIDE. 


\section{D I I F N E L E C TED.}

\section{L.$U R U S T I N U S$.}

This is one of the prettiest of evergreen shrubs, and is the gift of Spain to our highly-favoured land. In winter it is the ornament of our groves, displaying its shining leaves and snowy white flowers when other trees have ceased to bloom.

Neither the hot breath of summer nor the cold kiss of winter can rob it of its charms; but to preserve it we must tend it with assiduous care. The symbol of a kind and delicate friendship, it ever seeks to please, yet dies if neglected.

While you cherish me, dearest, "through good and through ill,"

Life's summer I'll bless, and its winter defy!

'Mid sunshine and tempest, I'll smile on thee still;

But oh! if you ever neglect me, I die !

While you watch o'er Love's glowing but delicate flowers,

Every glance of affection - each soul-winged sigh All the liloom of my cheek and my heart - shall be yours;

But oll! if you leave me-you leave me to die!

F. S. 0 . 


\section{ILLUSTRATION OF PLATE.}

Scarlet Geranium. - Scarlet Ipomcea. - Laurustinus.

In preference, I attach myself to you, but shall die if neglected.

I know that thou art true to me now; But I fear that, when far, far away, In the light of some beautiful brow, The flower of faith may decay!

I have seen thee look on a bright eye, love, And gaze as thou wouldst on a star;

And I've murmured, with many a sigh, love, " "How blessed the beautiful are!"

Yet, if passion and truth, warm and deep,

As ever in woman's heart met, Have a spell, man's affection, to keep,

I know thou wilt never forget! 


\title{
I PAR'TAKE Y.OUR SEN'TIMEN.TS.
}

\author{
G A R DEN-DAISY.
}

Within the garden's cultured round

It shares the sweet carnation's bed.

J. MontGoBiery.

THE daisy, like many other plants, undergoes a considerable change, when transplanted from its native field to the cultivated parterre. To preserve them, however, in their altered state, it seems necessary to divide the roots and transplant them every year. They thrive best in a moist loamy soil, without any admixture of manure ; and continue in flower for a longer period if shaded from the heat of the mid-day sun.

The garden daisy has been adopted to express reciprocity of feeling, in reference to an ancient custom in the days of chivalry. When the mistress of a knight permitted him to engrave this flower on his scarf, it was understood as a public avowal that she partook of his sentiments. Leyden has favoured us with some beautiful lines on the daisy, in which he alludes to this custom :-

Star of the mead ! sweet daughter of the day, Whose opening flower invites the morning ray, From thy moist cheek, and bosom's chilly fold, 'To kiss the tears of eve the dewdrops cold!

Sweet daisy, flower of love! when birds are paired, ' $T$ is sweet to see thee, with thy bosom bared, Smiling, in virgin innocence, serene, Thy pearly crown above thy vest of green. The lark, with sparkling eye, and rustling wing, Rejoins his widowed mate in early spring, And as she prunes his plumes of russet hue, Swears, on thy inaiden-blossom, to be t:ue.

Oft have I watched thy closing buds at ere, Which for the partiug/sunbeams seemed to grieve, And, when gay morning gilt the dew-bright pluin, Seen them unclasp their folded leaves again. 
Nor he who sung - "the daisy is so sweet"-

More dearly loved thy pearly form to greet;

When on his scarf the knight the daisy bound,

Anú dames at tourneys shone, with daisies crowned,

And fays forsook the purer fields above,

To hail the daisy, flower of faithful love.

Did not our countryman, James Montgomery, illustrious in the annals of poetry, partake warmly of the sentiments of that learned Baptist missionary, Dr. Carey, when he composed those beautiful lines, entitled "The Daisy in India," and which we here present to the reader, as they must awaken a kindred feeling in every heart where sensibility is not entirely extinguished? Dr. Carey had expressed, in a letter to a botanical friend in England, the pleasure he felt on observing a daisy spring up, unexpectedly, in his garden at Serampore, where he was stationed on his important duty. It had been borne over the waters in some English earth in which other seeds were conreyed; and now in another clime it opened its "crimsontipped flower" to the warm air of the East; we can conceive the welcome surprise with which the little flower was greeted!

Thrice welcome, little English flower!

The mother-country's white and red,

In rose or lily, till this hour,

Never to me such beauty spread;

Transplanted from thine island-bed,

A treasure in a grain of earth,

Strange as a spirit from the dead,

Thine embryo sprang to birth.

Thrice welcome, little English flower!

Whose tribes beneath our natal skies

Shut close their leaves while vapours lower;

But when the sun's gay beams arise,

With unabashed but modest eyes

Follow his motion to the west,

Nor cease to gaze till daylight dies,

Then fold themselves to rest. 
Thrice welcome, little English flower !

To this resplendent hemisphere,

Where Flora's giant offspring tower

In forgeous liveries all the year;

Thou, only thou, art little here,

Like worth unfriended or unknown,

Yet to my British heart more dear

Than all the torrid zone.

Thrice welcome, little English flower!

of early scenes beloved by me,

While happy in my father's bower,

Thou shalt the blithe memorial be,

The fairy sports of infancy,

Youth's golden age, and manhood's prime,

Home, country, kindred, friends - with thee--

Are mine in this far clime.

Thrice welcome, little English flower!

I'll rear thee with a trembling hand;

Oh! for the April sun and shower,

The sweet May-dews of that fair land,

Where daisies, thick as starlight, stand

In every walk! - that here might shoot

Thy scions, and thy buds expand,

A hundred from one root!

Thrice welcome, little English flower!

To me the pledge of hope unseen;

When sorrow would my soul o'erpower

For joy's that were, or might have been,

I'll call to mind, how - fresh and green -.

I saw thee waking from the dust;

Then turn to heaven, with brow serene,

And place in God $m_{i}^{\top}$ trust. 


\section{WILL ENLIGHTEN YOU.}

\section{WAX MIYRTLE.}

THE green berries of the wax inyrtle are boiled by the country people, and mould ed into zandles, which give a remarkablv clear and brilliant light.
Sweet, let us read our hearts together, By the pure, fragrant lamp of Love! 'T will steadily burn, in stormy weather, As now - for it was filled above.

F. S. 0 .

\section{TRUST IN THEE. \\ PERUVIAN HELIOTROPE.}

This evergreen trailer is a native of Peru, and bears beautiful ilac-coloured flowers; and, in the greenhouse, continues in bloom nearly the whole of the year.

The Orientals say that the perfumes of the heliotrope elevate their souls toward heaven; it is true that they exhilarate us, and produce a degree of intoxication. The sensation produced by inhaling them, may, it is said, be renewed by imagination, even though years have passed away after the reality was experienced.

The Countess Eleanora, natural daughter of Christian IV., king of Denmark, who became so notorious by the misfortunes, crimes, and exile of Count Ulfeld, her husband, offers to us a striking proof of the power of perfumes on the memory. This 
princess, at the age of thirteen, had become attached to a young man to whom she was subsequently affianced. This young man died in the castle where they were making preparations for the marriage. Eleanora, in despair, wished to take a long last look at the object of her love; and, if alive, to bid a last adieu. She was conducted into the chamber where he had just expired. The body was already placed on a bier, and covered with rosemary. The spectacle made such a deep impression upon the affianced maiden, that, though she afterward exhibited courage equal to her misfortunes, she never could breathe the perfume of rosemary without falling into the most frightful convulsions.

The celebrated Jussieu, while botanizing in the Cordilleras, suddenly inhaled the most exquisite perfumes. He expected to find some brilliantly-coloured flowers, but only perceived some pretty clumps of an agreeable green, bearing flowers of a pale blue colour. On approaching nearer, he observed that the flowers turned gently toward the sun, which they appeared to regard with reverential love. Struck with this peculiar disposition, he gave the plant the name of heliotrope, which is derived from two Greek words, signifying "sun," and "I turn." The learned botanist, delighted with this charming acquisition, collected a quantity of the seeds, and sent them to the Jardin du Roi, at Paris, where it was first cultivated in Europe. The ladies collected it with enthusiasm-placed it in their richest vases - called it the flower of love - and received with indifference every bouquet in which their favourite flower was not to be found.

An anonymous writer has made it emblematical of flattery, as it is said that when a cloud obscures the sky, it droops its head. We would rather suppose that, like the lover, whose heart is sad when absent from his mistress, so the heliotrope droops because it is deprived of the cheering rays of the sun that it seems to ad re.

There is a flower whose modest eye Is turned with looks of light and love 
Who breathes her softest, sweetest sigh, Whene'er the sun is bright above.

Let clouds obscure, or darkness veil, Her fond idolatry is fled;

Her sighs no more their sweets exhale The loving eye is cold and dead.

Canst thou not trace a moral here, False flatterer of the prosperous hour?

Let but an adverse cloud appear, And thou art faithless as the flower'

Should foes assail me,-

Or friendship fail me,

I'll ne'er bewail me,

I trust in thee!

Why should I sorrow?

Thou It smile to-morrow, And still I'll borrow

My light from thee!

F. s. 0 .

I M A G I N A T I O N.

\section{ALOE.}

THE aloe is said to thrive best in the desert, and is only attached to the soil by a very slender fibre. Its taste is very sharp and bitter. This plant derives its support almost entireIy from the air, and assumes very singular and fantastic shapes. La. Vaillant found many species very numerous in the deserts of Namaquois ; some of them six feet long, which were thick and armed with long spines. From the centre of these a light 
twig shoots forth to the height of a tall tıee all garnislsed with flowers. Others exalt themselves like the cactus, bristling with thorns. Others again are marbled and seem like serpents creeping upon the earth.

Brydone saw the ancient city of Syracuse entirely covered by great aloes in flower; their elegant branches giving to the promontory which bounded the coast, the appearance of an enchanted forest.

These magnificent and monstrous members of the vegetable kingdom are also found in barbarous Africa. There they grow upon the rocks in arid and sandy soil, in the midst of that burning atmosphere in which scarce aught but tigers and lions can breathe alive.

For rich Imagination's jewelled wand,

With living forms can fill the lonely hall;

With glorious bloom, enwreath the di sert-sand,

And crown again, with sculpture's grace, the ruined .empie's wall!

F. S. 0 .

\section{N T OXICATIO N}

VINE.

'THE grateful juice of the vine has been given to cheer the heart of man, but alas! it is too often used as the excitement to unseemly revelry, where men degrade the nselves to the condition of the brutes, : ver which they were created lords. 
AND FLOWERS OF POETRT.

But all the golden goblet has wrought, Is not of the evil kind;

It has helped the creature of mighty thought, And quickened the godlike mind.

Eliza Coor.

I WILL NOT TROUBLE YOU.

\section{A ROSELEAF.}

There was an academy at Amadan, whose statutes were couched in these terms: "The academicians think much, write little, and talk less!" Dr. Zeb, celebrated all over the East, being informed of a vacancy in that academy, hastened to obtain it, but uniortunately arrived too late. The academy was in despair ; it had just granted to power that which belonged to merit aione. The president, not knowing how to express a refusal which reflected so much discredit on the assembiy, commanded a cup to be brought, which he so exactly filled with water, that one more drop would have caused it to overflow. The learned candidate understood by this emblem that there was no place in the academy for him. He was retiring in disappointment, when he perceived a roseleaf at his feet. At this sight hope revived; he took the roseleaf and placed it so gently upon the water which filled the cup, that not a single drop was lost. At this ingenious feat every one clapped his hands, and the doctor was received by acclamation among the members of the silent academy.

You say your heart is now so full Of trouble and of wo, 
It wants but Love's first trembling tear To make it overflow.

Sweet girl! believe me, Love would bring Only a roseleaf there, Whose floating bloom would bless the tide, And calm the waves of care!

F. S. 0 .

\section{W I L L TH I N O F I T.}

\section{WHITE DAISY.}

In the bygone days of chivairy, when a lady wished to intimate to her lover tnat she was undecided whether she would accept his offer or not, she decorated her head with a frontlet of whute daisies, which was understood to say: "I will think of it."

"I dare not yet your prayers requite!" Exclaimed a fearful beauty;

"In Reason's golden scales, sir knight, I 'll weigh my love and duty."

Love drooped his wings in grief and shame;-

The scales began to waver; But then-a sigh, so heavy, came-

It turned them in his savour. 
AND FLOWERS OF POETRY.

\title{
ILLUSTRATION OF PLATE
}

\author{
Balsam. - White Daisy.
}

Be not impatient, I will think of it.

OH! bid me not so soon decide, On what, through life, to me, Or weal or wo my heart betide,

A changeless fate must be!

The gamester pauses ere he toss

The dice, on which depends

His worshipned gold - that glittering dross,

Which with existence ends; -

But I must stake a priceless wealth -

Hope - happiness and love -

My peace on earth - my young heart's health -And more - my bliss above!

5. \&. 0 . 


\section{M M R T A I T Y.}

\section{AIARANTH.}

The amaranth is one of the latest gifts of autumn, ar d when dead its flowers retain their rich scarlet colour. The ancients have associated it witl supreme honours; choosing it to adorn the brows of their gods. Poets have sometimes mingled its bright hue with the dark and gloomy cypress, wishing to express that their sorrows were combined with everlasting recolsections. Homer tells us, that, at the funeral of Achilles, the Thessalians presented themselves wearing crowns of a maranth.

Milton, in his gorgeous description of the court of heaven, mentions the amaranth as being inwoven in the diadem of angels.

Love and friendship are adorned with amaranth. In the garland of Julie, we find the four following lines:

Je suis la fleur d'amour qu'amarante on appelle,

El quiviens de Julie adorer les beaux yeux.

Roses, retirez-rous; jai le nom d'immortelle,

Ii n'appartient qu'à moi de couronner les dieus.

Criristina, queen of Sweden, who wished to immortalize herself by renouncing the throne to cultivate letters and philasophy, instituted the order of "knights of the amaranth." The decoration of that order is a medal of gald, enriched with a flower the amaranth in enamel, with this motto: "Dolce nella memoria."

In the floral games a: Toulouse, the prize for the best lyrical verses is a golden amaranth.

Fling, fling the wreath of Bacchus down!

For they who wear its vine-leaves here,

Forego the glorious amaranth-crcwn

Of angels in a 1 ulier spliere. 


\section{M P A T IE N C E.}

\section{BALSAM.}

THis plant, which is one of the most beautiful and delicate of popular annuals, is a native of East India, and forms a showy cone of carnation-like flowers, finely variegated. It possesses the peculiar property of retaining, during the hottest months of summer, all its freshness and beauty, while many other plants are withered before they have flowered. It has been named Nolitangere and Impatiens, from the curious fact that, when the seeds are ripe, they are thrown with considerable force out of the capsules on their being slightly touched; on this account it has been made the emblem of impatience. The Turks use it to represent ardent love.

The maid, whose manners are retired, Who patient waits to be admiredThough overlooked, perhrps, awhile, Her modest worth - her modest smile Oh! she will find, or soon or late, A notle, fond, and faithful mate.

PAULDING.

\section{N C O N S T A N C Y.}

\section{EVENING PRIMROSE.}

Turs oefutiful flower is a general favourite with our poets, who give it a very different character to that we have assigned 
to it in floral language. We presume that it has been made the emblem of inconstancy on account of the transient duration of its flowers. It opens between six and seven o'clock in the evening.

When once the sun sinks in the west, And dewdrops pearl the Evening's breast;

Almost as pale as moonbeams are, Or its companionable star, The evening primrose opes anew Its delicate blossoms to the dew; And, hermit-like, shunning the light, Wastes its fair bloom upon the Night, Who, blindfold to its foud caresses, Knows not the beauty he possesses. Thus it biooms on while Night is by ; When Day looks out with open eye, 'Bashed at the gaze it cannot shun, It faints, and rithers, and is gone.

Clare's Rural MIUse.

\section{N D I F F E E N C E.}

\section{CANDY-TUFT.}

Trie iberis continues in $b_{1}$ ossom nearly tne whole year, ever presenting to us its bright green ioliage, and its scentless blossoms white as snow. The tirst specimen of this plant was brought from Candia, whence Its English name candy-tuft. 'The plant is well adapted to enliven the sombre appearance of 
our evergreen plantations during the winter months, if not placed near the Laurustinus, which requires no aid of this kind; for that beautiful shrub, like the iberis, seems awake while the rest of vegetable nature sleeps.

The warmth of our summers has very little apparent effect upon the candy-tuft; the gardener is frequently obliged to tear away the flowery veil which persists in concealing its seed.

It braves all the inclemencies of winter; aid if we are reminded by its brilliancy of that of other flowers, we are less consoled for their absence, than led to regret their graces and sweet perfumes.

It is doubtless by reason of its unvarying appearance that the Eastern ladies, who first ascribed the power of language tc flowers, have made the iberis the emblem of indifference.

Better the tie at once be broken, At once our last farewell be spoken, Than watch him, one by one, destroy The glowing buds of hope and joy Than thus to see them, day by day, Beneath his coldness fade away!

5. S. 0 .

\section{N F I D E L I T Y.}

\section{FELLOW ROSE.}

$\therefore$ is well known that yellow is the colour of infidelity. The yellow rose also seems to appertain to the unfaithful in love or friendship. Water injures it; the sun scorches it; and this scentless flower, which profits neither by attention nor lib- 
erty, seems only to prosper under restraint. When we wish to see them in their full brilliancy, it is necessary to incline the buds toward the earth, and keep them in that position by force.

But if for me thou dost forsake Some other maid, and rudely break Her worshipped image from its base, To give to me the ruined place;

Then fare thee well - I'd rather make My bower upon some icy lake, When thawing suns begin to shine, Than trust to love sn false as thine!

MÍOORE.

I N D I S C RETION.

\section{$\triangle L$ IOND-TREE.}

Like to an almond-tree, mounted high On top of green Selinis, all alone, With blossoms brave bedecked daintily; Whose tender locks do tremtie every one, At every little breath that under heaven is blown.

Faery Queene.

Endrem of indiscretion, the almond-tree is the first to answer to the call of spring. Nothing is more lovely and fresh in its appearance than this beautiful tree, when it appear's covereci with flowers. The later frosts not unfrequently destroy the too precocious germes of its fruits; but it is remarkable that the beauty of its flowers, far from being injured, is increased in 
brilliancy. An avenue of almond-trees, all white in the evening, struck with the frost in the night, will be of a rose-colour the following morning, and retain this new attire for more than a month, the flowers never falling until the tree is covered with verdure.

The early appearance of the almond-tree seems formerly to have afforded an omen to the agriculturist. Dryden mentions it as such :-

Miark well the flowering almonds in the wood:

If od'rous blooms the bearing branches load,

The glebe will answer to the sylvan reign;

Great heats will follow, and large crops of grain.

Fiction gives us an affecting account of the origin of the almond-tree; it relates, that Demophoun, the son of Theseus and Phædra, when returning from the siege of Troy, was cast by a tempest on the coasts of Thrace, where the beautiful Phyllis then reigned. The young queen welcomed the prince, and becoming enamoured of him, at length married him. Demophoon was recalled to Athens by the death of his father; but promised to return to his beloved Phyllis at the expiration of a month, and fixed the day. The tender Phyllis counted every minute during his absence, until the longed-for period arrived. Phyllis ran to the shore nine times; but, having lost all hope, she died of grief, and was changed into an almond-tree. Demophoon returned three days afterward in despair; he offered a sacrifice on the seashore to appease the manes of his beloved. She appeared sensible of his repentance and his return, for the almond-tree, which enclosed her in its bark, blossomed instantaneously; proving by this last effort that death had wrought no change in her affections.

Oh! lovely still! yet lost as lovely - thou Dost veil the dazzling fairness of thy brow, And droop thy lids o'er blue and beauteous eyes, Where, all too late, the tears of shame arise!

F. S. 0 . 


\section{N G R A T I T U D E.}

BUITERCUPS.

THIs plant contains many virulent qualities, which are said to affect cattle, especially sheep, and particularly the root, which has the property of inflaming and blistering the skin.

Clare, the Northamptonshire poet, alludes to its ungrateful qualities in some lines on the "Eternity of Nature." Detailing his morning's walk, he says :-

\section{I wander out and rhyme;}

What hour the dewy morning's infancy Hangs on each blade of grass and every tree. And sprents the red thighs of the humble bee, Who 'gins betimes unwearied minstrelsey; Who breakfasts, dines, and most divinely sups, With every flower save golden buttercups On whose proud bosoms he will never go, But passes by with scarcely "How do ye do?" Since, in their showy, shining, gaudy cells, Haply the summer's honey never dwells.

\section{N N O C E N C E.}

\section{DAIS Y .}

The English name of daisy is derived from a Saxon word, meaning day's eye, in which way Ben Jonson writes it; and Chaucer calls it the "eie of the daie." We presume that it is called day's eye, from the nature of its blossom, which opens at daybreak, and closes at sunset:

The little daizie, that at evening closes.

SPENSER. 
The following address to the daisy is from Wordsworth, and we think that it will excite in all minds agreeable reminiscences of days of childhood:-

In youth, from rock to rock I went,

From hill to hill in discontent,

of pleasure high and turbulent,

Most pleased when most uneasy;

But now my own delights I make-

My thirst at every rill can slake,

And gladly Nature's love partake

of thee, sweet daisy!.

When Winter decks his few gray hairs, 'Thee in the scanty wreath he wears;

Spring parts the clouds with softest airs,

That she may sun thee;

Whole summer-fields are thine by right,

And Autumn, melancholy wight!

Doth in thy crimson head delight,

When rains are on thee!

In shoals and bands, a morrice train,

Thou greetest the traveller in the lane;

If welcomed once thou comest again;

Thou art not daunted;

Nor carest if thou be set at nought;

And oft alone, in nooks remote,

We meet thee, like a pleasant thought,

When such are wanted.

The violets in their secret mews,

The flowers the wanton zephyrs choose;

Proud be the rose, with rains and dews

Her head impearling;

Thou livest with less ambitious name,

Yet hast not gone without thy farne;

Thou art, indeed, by many a clair,

The poet's darling.

If 10 a rock from rains he $f y$,

()r some bright day of April's sky,

Imprisoned by hot sunshine lie

Near the green holly; 
And wearily at length should fare; He need but look about, and there Thou art ! - a friend at hand, to scare His melancholy.

A hundred times, by rock or bower, Ere thus I have lain couched an hour, Have I derived from thy sweet power

Some apprehension;

Some steady love; some brief delight;

Some memory that had taken flight;

Some charm of fancy, wrong or right;

Or stray invention.

If stately passions in me burn, And one chance look to thee should turn, I drink out of an humble urn

A lowlier pleasure;

The homely srmpathy that heeds The common life our nature breeds A wisdom fitted to the needs of hearts at leisure.

When, smitten by the morning ray, I see thee rise, alert and gay, Then, cheerful flower! my spirits play

With kindred gladness;

And when, at dusk, by dews oppressed Thou sinkst, the image of thy rest Hath often eased my pensive breast of careful sadness.

And all day long I number yet, All seasons through, another debt, Which I, wherever thou art met,

To thee am owing;

An instinct call it, a blind sense, A happy genial influence,

Coming, one knows not how, or whence, Nor whither going.

Child of the year! that round dost run Thy course, bold lover of the sun, And cheerful, when the day's begun,

As morning leveret - 
Thy long-lost praise thou shalt regain,

Dear shalt thou be to future men, As in old time; - thou, not in rain, Art Nature's favourite.

In Yorkshire, this plant is called dog-daisy; and in Scotland gowan, a name which in that country is also applied to the dandelion, hawkweed, \&cc.

The opening gowan, wet with dew.

We find it recorded in Milton's Comus, that

By dimpled brook and fountain brim, The wood-nymphs, decked with daisies trinı, Their merry wakes and pastimes keep.

"Malvina, leaning o'er Fingal's tomb, mourns for the valiant Oscar, and his son who died before he had seen the light.

"The virgins of IForven, to calm her grief, walk often around her, celebrating, by their songs, the death of the brave and the newborn.

"'The hero is fallen,' say they; 'he is fallen! and the sound of his arms echoes over the plain; disease, which takes away courage-age, which dishonours heroes - can no longer touch him; he is fallen! and the sound of his arms echoes over the plain!

" Received into the heavenly palace inhabited by, his ancestors, he drinks with them the cup of immortality. Oh! daughter of Oscar, dry thy tears of grief; the hero is fallen! he is fallen! and the sound of his arms echoes over the plain!'

"Then, in a softer voice, they said again to her: "The child who has not seen the light, has not known the bitterness of life; its young soul, borne on glittering wings, arrives with the diligent Aurora in the palace of day. The souls of children, who have, like it, broken the chains of life without sorrow, reclining on golden clouds, present themselves, and open to it the mysterious portals of Flora's cabinet. There this innocent 
troop, ignorant of evil, are for ever occupied in enclosing, in imperceptible seeds, the flowers that blow in each spring; every morn they scatter these seeds upon the earth with the tears of Aurora; millions of delicate hands enclose the rose in its bud, the grain of wheat in its folds the rast branches of the oak in a single acorn, and, sometimes, an entire forest in an invisible seed.

" "We have seen, oh, Malvina! we have seen the infant you regret, reclining on a light mist; it approached us, and has shed on our fields a harvest of new flowers. Look, oh, Malvina! among these flowers we distinguish one with a golden disk, surrounded by silver leaves; a sweet tinge of crimson adorns its delicate rays; waved by a gentle wind, we might call it a little infant playing in a green meadow. Dry thy tears, oh, Malvina! the hero is dead, covered with his arms; and the flower of thy bosom has given a new flower to the hills of Cromla.'

"The sweetness of these songs relieved Malvina's grief; she took her golden harp, and repeated the hymn of the newborn.

"Since that day the daughters of Morven have consecrated the daisy to infancy; ' it is,' said they, 'the flower of innocence, the flower of the newborn.'"

That old favourite - the daisy - born By millions in the balmy, vernal morn-The child's own flower.

Carrington.

Trampled under foot,

The daisy lives, and strikes its little root

Into the lap of time; centuries may come,

And pass away into the silent tomb,

And still the child, hid in the womb of ume, Shall smile and pluck them, when this simple rhyme 
Shall be forgotten, like a churchyard stone, Or lingering lie unnoticed and alone, When eighteen hundred years, our common date, Grow many thousands in their marching state, Ay, still the child, with pleasure in his eye, Shall cry - the daisy ! - a familiar cry And run to pluck it, in the selfsame state As when Time found it in his infant date; And, like a child himself, when all was new, Might smile with wonder, and take notice too; Its little golden bosom frilled with snow, Might win e'en Eve to stoop adown, and show Her partner, Adam, in the silky grass, The little gem, that smiled where pleasure was, And loving Eve, from Eden followed ill, And bloomed with sorrow, and lives smiling still; As once in Eden, under heaven's breath, So new on earth, and on the lap of death, It smiles for ever.

C'Lare.

\section{N Q U I T U D E.}

\section{A R Y G OL D.}

The marygold that goes to bed with the sun, And with him rises weeping.

Anon.

Madall Lebrun, in one of her charming pictures, has represented grief as a young man pale and languishing; his 
head appears to be bowed down by the weight of a garland of marygolds.

The marygold continues in flower the whole of the year, hence its scientific name calendula. Jis flowers open at nine o'clock in the morning, and close again at three o'clock in the afternoon. Like the heliotrope, it always turns toward the sun, following his course from east to west.

During the months of July and August, the marygold emits small luminous sparks during the night. This quality it possesses in common with the nasturtium and many other flowers of the same colour.

The mcurnful signification of the marygold can be modifiea in various ways. United with roses it is the emblem of the sweeter pains of love; alone, it expresses inquietule, or ennui. Woven with other flowers, it represents the inconstant chain of life, ever good and evil interwoven. In the East, a bouquet of marygold and poppies expresses this thought: "I will allay your pains."

Margaret of Orleans, maternal ancestor of Henry IV., had for her device a marygold turning toward the sun, with these words: "Je ne veux suivreque lui seul:" That virtuous princess wished to express by this device that all her thoughts and all her affections turned toward Heaven, as the marygold does to the sun.

Though born in the desert, and doomed by my birth, To pain and affliction - to darkness and dearth -

On thee let my spirit rely -

Like some rude dial, that, fired on earth, Still looks for its light from the sky!

Moore. 


\section{IN S P IR A T I O N.}

\section{AN IEIICA.}

THIs plant is named angelica in allusion to its agreeable smell and medicinal qualities. It has winged leaves divided into large segments; its stalks are hollow and jointed; the flowers grow in an umbel upon the tops of the stalks, and consist of five leaves, succeeded by two large channelled seeds. Archangelica is sometimes cultivated in gardens for its leafstalks, to be blanched and eaten as celery, or candied with sugar. In Lapland, where it is also found, it is used to crown puets, who fancy themselves inspired by its agreeable odour.

The muse of Inspiration plays O'er every scene; she walks the forest-maze, And climbs the mountain; every blooming spot Burns with her step, yet man regards it not!

Míore.

\section{R O N Y.}

\section{SARDONY.}

SARDONY has some resemblance to parsley; it contains a poison which is sald to contract the mouth in so peculiar a manner, that the individual affected seems to laugh in expiring. This horrible laugh has been named, Risis Sardonicus, or Sardonic langhter. It is that which we see playing on the lips of Satire, and on those of cold Irony. 
There was a lurking dévil in his sneer.

\section{BYron.}

When all around, with heartless mirth,

At deeds of virtuous daring rail;

Or coldly sneer at angel-worth,

Because its schemes of goodness fail;

One brow with generous anger glows,

One heart a mahlier verdict sends, One fearless voice unfaltering flows,

In warm defence of absent friends!

F. S. o.

\section{$\mathrm{JOY}$}

WOOD-SORREL.

THE wood-sorrel, vulgarly called "cuckoo's bread," flowers very freely about Easter. This pretty little plant shuts its leaves, closes its corollas, and the flowers hang pendent and drooping from the stems. They seem to yield themselves to sleep; but at the first dawn of day we may say that they are flled with joy, for they throw back their leaves, and expand their flowers; and we doubt not it is on this account that peasants have said that they sing the praises of their Creator. 
THE FLOWER PLAF.

How soon a bright and happy child

Will catch our playful tone, And, glad to have a frolic wild,

Match our mirth with her own!

1 said to Anna once - "Good night My precious Mignionette!"

And she replied, with quick delight "Good night, my Violet!"

I tried again - "Good night, my Pink, My Jessamine, my Laurel!"

She pressed her lip - "I cannoi think Oh, yes! good night, my Sorrel!"'

Once more I spoke in pleased surprise"Good night, my little Foxglove!"

She answered me with laughing eyes "Good night, my piece of Box, love!"

I thought to tire her baby-brain; But no! she'd not give up.

"Good night, my Rose!" - she laughed again "Good night, my Buttercup!"

But little versed in Flora's lore, Is Anna;-yet an hour, She racked her infant mind for more, And gave me flower for flower' 


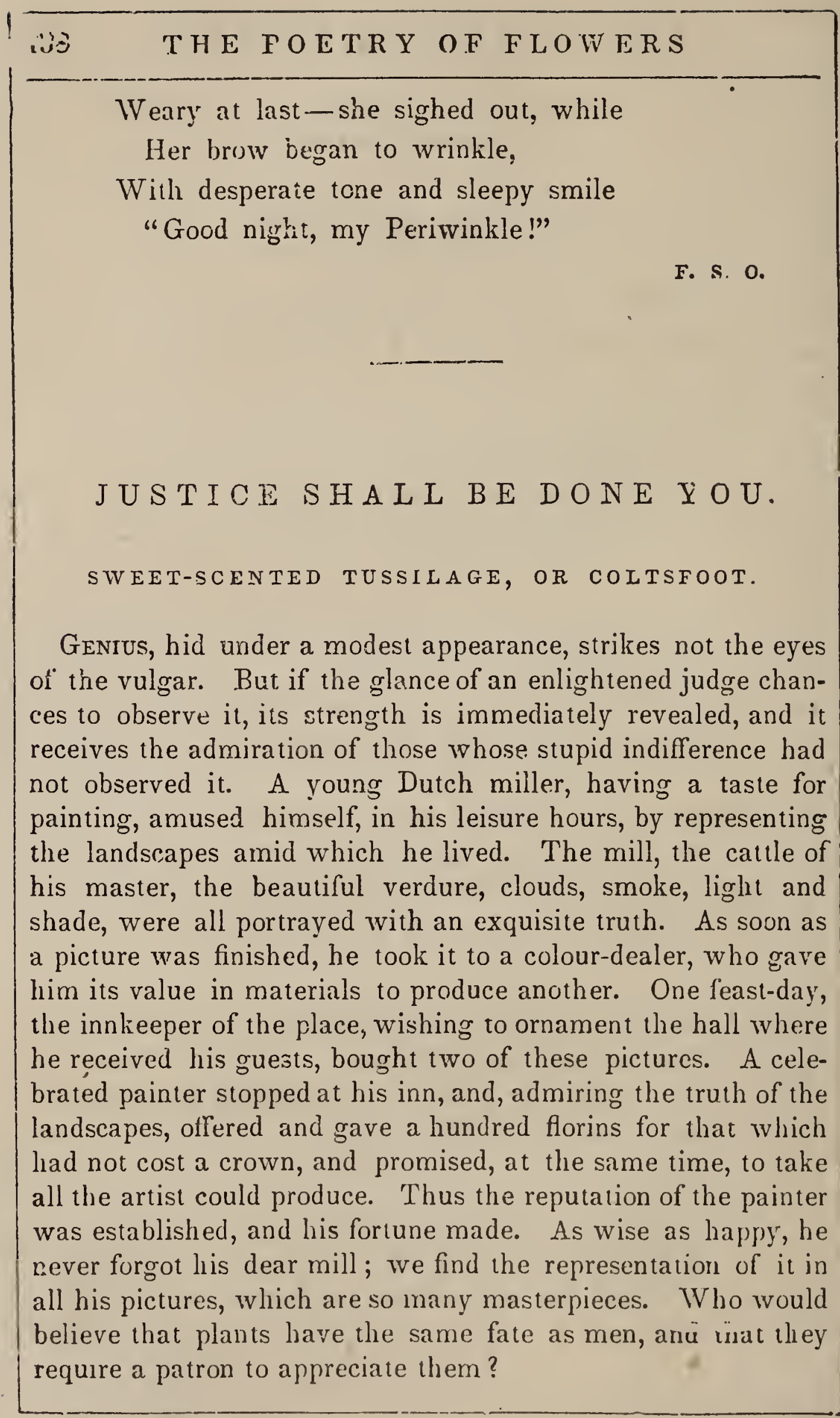


Coltsfoot, notwithstanding its sweet smell, had remained a long time unknown at the foot of Mount Pila, where no doubt it would still have bloomed in obscurity, if a learned botanist, M. Villau de Grenoble, had not appreciated its beneficent qualities. This perfumed plant appears at a season when all others have disappeared. As the great artist eulogized the poor painter, so did M. Villau the humble flower; he gave it a distinguished rank in his works ; and, since then, the tussilage has been cultivated with care, and perfumes our brilliant saloons.

They shall own thee the sweetest and fairest of flowers, That smile in our woodlands, or blush in our bowers! They shall own thee a lovelier gem of delight, Than they that illumine the veil of Midnight!

F. S. O.

\section{KEEP YOUR PROMISES.}

\section{PLUUITRE.}

Every year the plum-tree is covered with an immense quantity of flowers, but unless trained and pruned by the hand of an able gardener of all its superfluous wood, it will only yield fruit once in three years.

Come! thou hast not forgotten

Thy pledge and promise quite, With many blushes murmured

Beneath the evening light;- 
Come, the young violets crowd my door,

Thy earliest look to win,

And at my silent window-sill

The jessamine peeps in.

All day the red-bird warbles

Upon the mulberry near,

And the night-sparrow trills her song

All night with none to hear.

BrYanT.

\section{E T M E G O ! \\ BUTTERFLT-WEED.}

The asclepias tuberosa or butterfly-weed is found in abundance in the United States. Its flowers are of a beautifully bright orange colour. The down or silk of the seeds, in this and other species, furnishes an admirable mechanism for their $i$ dissemination. When the seeds are liberated by the bursting | of the follicle which contains them, the silken fibres immedi- , ately expand so as to form a sort of globe of branching and, highly attenuated rays, with the seed suspended at its centre. In this state they are elevated by the wind to an indefinite height, and carried forward with a voyage like that of a talloon, until some obstacle intercepts their flight, or rain precipitates them to the ground.

Nay! ourd is not the morning

Of love, when all :s fresh and sweet,

I often catch you yawning, You know, where'er we meet. 
For me - I must confess, love,

I'm growing rather bored - and so

Take back this golden tress, iove, And let me-let me-go!

F. S, 0 .

\section{I F E.}

LUCERN.

LUCERN occupies the same ground for a long period, but when it forsakes it, it is for ever. On this account it has been made the emblem of life.

Life is a fair, nay charming form, Of nameless grace and tempting sweets;

But disappointment is the worm, That cankers every bud she meets.

\section{NEELE.}

A blossom full of promise is life's joy, That never comes to fruit; Hope, for a time, Suns the young floweret in its gladsome light, And it looks flourishing; - a little while ' $\mathrm{T}$ is past, we know not whither, but ' $t$ is gone! Miss Landon.

Life is a waste of wearisome hours,

Which seldom the rose of enjoyment adorns; And the heart that is soonest awake to the flowers, Is always the first to be touched by the thorns. MLoRE. 


\section{$\mathrm{L} \cap \mathrm{VF}$}

MIRTLE.

See, rooted in the earth, her kindly bed, The unendangered myrtle, decked, with flowers, Before the threshold stands to welcome us !

WORDSWORTR.

THE oak has ever been consecrated to Jupiter - the laurel to Apollo - the olive to Minerva - and the myrtle to Venus. Among the ancients the myrtle was a great favourite, for its elegance, and its sweet and glossy evergreen foliage. Its perfumed and delicate flowers seem destined to adorn the fair forehead of love, and are said to have been made the emblem of love, and dedicated to beauty, when Venus first sprang from the sea. We are informed by mythological writers that when the fair goddess first appeared upon the waves, she was preceded by the Hours, with a scarf of a thousand colours and a garland of myrtle.

At Rome, the first temple dedicated to Venus was surround. ed by groves of myrtle; and after the victory that goddess achieved over Pallas and Juno, she was crowned with myrtle by Cupids. Surprised one day, on going out of a bath, by a troop of satyrs, she took refuge behind a myrtle-bush; she also avenged herself with myrtle branches on the audacious Psyche, who had dared to compare her own transitory graces to those of an immortal beauty.

Although triumphs are no longer celebrated in the Roman capitol, the Italian ladies have preserved a very lively passion for this lovely shrub; preferring its odour to that of the most precious essences, and throwing into their baths water distilled from its leaves, being persuaded that the tree of Venus is favourable to beauty. If the ancients had that idea - if the tree so consecrated to Venus were to them the tree of love - it was from the true analogy between its power and that of love, for wherever the myrtle grows it spreads itself around, to the ex- 
AND FLOWERS OF POETRY.

clusion of all other shrubs. So love, once master of a heart, leaves no room for any other sentiment. Scott has borne inis testimony to the universality of love:-

In peace, Love tunes the shepherd's reed;

In war, he mounts the warrior's steed;

In halls, in gay attire is seen;

In hamlets, dances on the green:

Love rules the court, the eamp, the grove, And men below, and saints above;

For love is heaven, and heaven is love.

$\mathrm{He}$ was among them ali -

The bright, the young, the fair;

But on his brow they marked a shade, A still deep shadow that betrayed,

E'en when he bowed at beauty's thrall,

His spirit was not there;

But sought a dearer light afar -

A gentler and a purer star.

He was among them all -

The bright, the young, the fair;

When softest eyes did softly glance,

And fairy feet were in the dance,

Dreaming, amid their music fall,

Of one who was not there;

Sighing to greet that light afar -

The gentler and the purer star.

He was among them all -

The bright, the young, the fair;

When music stolen from heaven above

Was gently breathed by lips of love, 
THE POETRY OF FI, OWER S

He heeded not the call;

But dreamed of notes more rich and rare, And worshipped still that light afarThe gentler and the purer star.

He was among them all -

The bright, the young, the farr; But ruby lips were vainly wreathed, And timid sighs as vainly breathed,

For him in pleasure's hall;

$\mathrm{He}$ might not greet her thereThe one he loved, the light afarThe gentler and the purer star.

He was among them all -

The bright, the young, the fair; When eyes looked soft in the moon's soft light, And tones grew low like the breath of night,

'Or music's dying fall,

Still, 'still, unconquered there,

His heart was hers who dwelt afar The gentler and the purer star.

He was among them all -

The bright, the young, the fairOnly to dream of hours more sweet, Wishing that he were at her feet,

Not midst the festive hall;

To see again her golden hair, Bound up for him - nis light afar The gentler and the purer star.

LUCY HOOPER. 
A N F LOWERS OF POETRY.

II, LUSTRATION OF PLATE.

Myrtle.-Sweetbrier._Lucern.

Love is the poetry of life.

Young Love is knocking at your heart; -

Open the lattice! let him in!

And blush not thus - nor sigh and start!

Love is not Shame, nor Grief, nor Sin.

Love is an angel in disguise!

Sent, with a band of brilliant flowers,

To bind the soul that, exiled, sighs,

And lead it home to Eden's bowers

Yield to the chain that heavenward woos:

Go! linked with Love, in bonds sn sweet! His wings will shower their rainbow hues, His wreath, its fragrance round your feet.

ร. ธ. ก. 


\section{OVE I N A S NOW-W R E A T H.}

MEZEREON.

ThE rose-coloured blossoms of this much-admired plant are often found smiling and blushing in the midst of snows in gay defiance of winter's farewell frown.

One wintry morn an icicle lay,

Chained, in the sunlight calm and clear,

To a graceful, delicate, frost-bound spray,

Like a diamond-drop in Beauty's ear.

My eye was caught by a strange, rich gleam,

That fitfully played in the pendant pure,

And I thought I saw two bright wings beam

Through the luminous ice; but I was not sure.

I stole to the place, and there-behold!

A fairy child in the icicle's lieart!

Tossing his tresses of curled gold,

Shaking his tiny, suntipped dart;-

Fluttering, striving his form to free,

Like a rainbow at play in a prison, he turned;

Laughing and frowning, as anger or glee,

By turns, in his bosom, smiled or burned.

I knew by his pinions of changeable light,

I knew by his quiver and cherub-bloom,

'T was the lovely and petulant cyprian sprite--

The boy-god - caught in that living tomb. 
But his sigh so soft, and his smile so warm,

Were melting the icicle fast away;

And lo! as I gazed, he freed his form,

And plumed his wings on the frost-bound spray.

"And how came you in it, sweet Love?" I cried;

He bit his lips as he answered low -

"I have been a fool for my pains; - I tried

Young Julia's heart, with a tale of wo:

"She pitied - received - and hushed me to sleep

On her tranquil breast, that knew no sin;

And o'er my form soft tears did weep,

But oh! so cold, they froze me in!

"I woke to find myself prisoned here,

In the palace of ice her tears had wrought;

And if ever I trust to a woman's tear

Again, may I be - in my own net, caught!"

He sighed - he shivered - shook off the last

Chill drops that hung on his plumes of light;

One rueful look upon me he cast,

Then rapidly rose and was lost to sight.

F. 80 . 


\section{I VEL A N P UREAFFECTION.}

\section{DINK.}

THE primitive pink is simple red or white, and perfumed. We occasionally observe where

\section{- the wild pink crowns the garden wall, And with the flowers are intermingled stones Sparry and bright, rough scattering of the hills.}

WORDSWORTII.

Cultivation has doubled the petals of this favourite flower, and procured for it an infinite variety of colouring, so that it is painteà with a thousand shades, from the delicate rose-colour to the perfect white: and from a deep red to a brilliant scarlet. In some varieties we observe opposite colours placed torgether on the same flower: the pure white is tipped with crimson, and the rose-coloured is streaked with lively and brilliant red. We also see these beautiful flowers marbled, speckled, and, at other times, bisected in such a manner that the deceived eye leads us to imagine that the same cup contains a purple flower, and one of palest alabaster. Nearly as varied in form as in colour, the pink always preserves its delicious perfumes, and continually labours to shed its foreign costume, and renew its native attire. For though the hand of the gardener can double and triple, and variegate its dress, it cannot render its acquired qualities permanent. Thus nature has deposited in our hearts the germes of the most excellent sentiments. Art and society altivate and develop these, embellishing, enfeebling, or exalting them. A variety of causes uniting, are able to render their effects inconstant and changeable; but, in spite of the caprices, errors, and incornprehensible sports of the human heart, nature always brings back affection to its primitive simplicity.

There is an anecdote connected with the pink, which shows how far the mind way be led away and debased by the arts of flattery:- 
"The young duke of Burgundy, grandson of Louis the Fifteenth, being fond of cultivating these flowers, a flatterer persuaded him, by substituting other pots of pinks for those which the prince had reared, that the pinks which he planted came up and flourished in one night. Thus persuaded, the youthful prince believed that Nature obeyed his will. One night, not being able to sleep, he éxpressed a wish to get up, but was told that it was then the middle of the night: ' Well,' replied he, "I will have it be day.",

Oh, woman's love! at times it may

Seem cold or clouded, but it burns

With true, undeviating ray,

$\Lambda$ nd never from its idol turns.

Its sunshine is a smile - a frown

The heavy cloud that weighs it down:

A tear its weapon is - beware

Of woman's tears - there's danger there!--

Its sweetest place on which 10 rest,

A constant and confiding breast:

Its life to meet - its death to part-

It sepulchre, a broken heart.

CROIT.

\section{U X U R Y.}

HORSE-CHESTNUT.

This magnificent tree was originally brought from India, and has been naturalized in Europe for more than two centuries, but yet we do not see it raise its gorgeous head arnong our 
forest-trees. It is well suited to be an ornament in parks; to adorn the castles of nobility, and to shade the residence of kings. It luxuriates at the Tuileries, where it rises around the great pond in masses of incomparable beauty. At the Luxembourg it spreads its branches in accordant pomp and spiendour; -

There avenues of chestnuts high

With vaulted roofs conceal the sky.

In the beginning of spring, one rainy day is sufficient to cause this beautiful tree to cover itself with verdure. If it be planted alone, nothing surpasses the elegance of its pyramidal form, the beauty of its foliage, or the richness of its flowers, which sometimes make it appear as an immense lustre or chandelier, all covered with pearls. Fond of ostentation and richness, it covers with flowers the grass which it overshadows, and yields to the idler a most delightful shade. To the poor man it is of little service, supplying him with nothing more than a light and porous timber, and a bitter fruit. Naturalists and phy sicians have attributed to this child of Asia a thousand gobd qu $x$ ities which it does not possess.

Sunny-haired Eloise! wealth is thme own;

Kicn is thy silken robe - bright is thy zone;

Diamonds, like star-drops, thy silken braiảs deck;

Pearls waste their snow on thy lovelier neck;

I.uxury softens thy pillow for sleep-

Angels watch over it! - Why do you weep?

F. S. D 


\section{A J E S T Y. \\ CROWN IMIPERIAL.}

ON this family of plants modern botanists have bestowed the name of Fritillaria, of which this, from its commanding de. portment and brilliant colours, is considered the sovereign.

The lily's height bespolie command,

A fair imperial flower;

She seemed designed for Flora's hand,

The sceptre of her power.

We have therefore elevated this distinguished member of Flora's kingdom to be the emblem of majesty, and the representative of power in our floral sentiments.

Art thou not noble? then thy brow belies thee!

Thou art! I read it in thy proud dark eyes,

Whose glance is truth and love, and in those lips,

Whose smile is but a ray of the soul's sunshine;

In thy high bearing, in thy movements, words; -

Thou art of hearn's nobility - as far

Excelling earth's, as doth yon winged star,

Robed in its garment of celestial glory,

Outshine the earth-bound glow-worm.

F. S. o. 


\section{MATERNAL L O E.}

\section{A TUFT OF MOSS.}

J. J. Rousseau was ardently fond of the study of botany; and of all plants the family of mosses delighted him most. He would often remark that they gave an air of youth and freshness to our fields, adorning nature when flowers had vanished. The stunted stems of dead and leafless trees are oft clad with a mossy verdure.

Like to those friends whose affection ceases not when misfortune assails us, and whose kind services even ingratitude cannot repel, the mosses, exiled from cultivated fields, advance toward the barren and untilled land, which they cover with their own substance, and by degrees transform it in to a fruitful soil. In winter it is said that they are charged with hydrogen and carbon, so as to infect the air; but in summer, beds of moss are formed in the umbrageous shades of forests and plantations, where the shepherd, the lover, and the poet, are equally delighted to repose; and we may add, with Carrington, tlee traveller too:-

Here, trareller, rest thee, for the sun is high, And tho's art old and weary. It is sweet

To find, at noon, a moorland bank like this, To press its luxury of moss, and bid

The hours flet by on burning wing. Awhile Repose thou in the shade, this stunted tree Grasped by the choking iry - of his race The last - has foliage yet enough to screen Thine ardent brow; and just below, a brook, Fresh from the ever-living spring, presents Its purest crystal to thy lip.

The little birds use the delicate moss in the formation of their nests. Is this instinct? Yea, truly the instinct of maternal care, and maternal tenderness, implanted by nature in 
the light-winged inhab:tants of the air. Clare shall tell us of the thrush preparing her nest :-

Within a thick and spreading hawthorn bush, That overhangs a molehill large and round.

1 heard, from morn to morn, a merry thrush

Sing hymns to sunrise, and I drank the sound

With joy; and, often an intruding guest,

I watched her secret toils from day to day -

How true she warped the moss, to form a nest,

And modelled it within with wood and clay;

And by-and-by, like heath-bells gilt with dew, There lay her shining eggs, as bright as flowers, Ink-spotted over shells of greeny blue; And then I witnessed, in the sunny hours,

A brood of Nature's minstrels chirp and fly, Glad as that sunshine, and the laughing sky.

The squirrel also uses it in the construction of its circular abode.

The Laplanders, we are told, protect themselves from the rigours of winter by covering their subterraneous dwellings with moss; their numerous herds of raindeer know no other food; yet they yield their owners a delicious milk, a succulent flesh, and warm skins; affording the poor Laplander all the benefits we derive from the cow, the horse, and the sheep. On the appearance of the aurora-borealis, which cheers their long nights, the Laplanders assemble around poles, and celebrate, to the beating of the tambour, the virtues or warlike deeds of their forefathers; while their wives are seated near them, cherishing, in moss cradles, their little infants, enveloped in ermine.

Beneficent nature, in those dreary climes, surrounds everything with mosses, to preserve her children from the biting fiosts, and to nourish them upon her maternal bosom.

Ere yet her child has drawn its earliest breath,

A mother's love begins - it glows till death;

Lives before life - with death not dies - but seems

The rery substance of immortal dreams.

Axon. 


\section{E L A N C H O L Y.}

\section{WEEPING-WILLOW.}

By the waters of Babylon we sat down and wept, when we re. membered thee, O Sion! As for our harps, we hanged them up upon the willows that are therein.

WE cannot conceive a more touching appeal to human sympathy, than the mournful complaints of the daughters of Jerusalem. Their Babylonish conquerors having led them a way captive, required of them "a song, and melody in their heaviness; "Sing us one of the songs of Sion." But the hearts of her children were surcharged with grief, and they asked: "How shall we sing the Lord's song in a strange land?" They were oppressed with sorrow - they were bowed down with affliction - they "hanged their harps upon the willows, and sat down and wept." Is not then the weeping-willow a sacred emblem of melancholy?

My gentle harp! once more I waken

The sweetness of thy slumbering strain;

In tears our last farewell was taken,

And now in tears we meet again.

No light of joy hath o'er thee broken,

But - like those harps, whose heavenly skill

Of slavery, dark as thine, hath spc'ien -

Thou hangst upon the willows still.

The weeping-willow is a native of the East, and is greatly admired for its drooping pendulous branches, waving over our lakes and streams.

Thus o'er our streams dn Eastern willows lean

In pensive guise; whose grief-inspiring shade,

Love has to melancholy sacred made.

DELILLE. 
It grows wild on the coast of Persia, and is common in China. The celebrated specimen in Pope's garden at Twickenham, is said to have been the first introduced into England; but this we believe to be erroneous. The poet chanced to be present on the opening of a package which came from Spain, and observing that the sticks had some vegetation, fancied they might produce something which we did not possess in England. With this idea he planted a cutting, from which sprang the parent-tree of many of our finest and most admired specimens.

How vain the task to wake my lyre To rapture's thrill, with passion's fire, While sorrow o'er my heart-strings plays, With trembling touch, her saddest lays! F. S. 0.

\title{
MELANCHOLY SPIRIT.
}

\author{
SORROWFUL GERANIUN.
}

Few know that elegance of soul refined, Whose soft sensation feels a quicker joy From melancholy's scenes, than the dull pride Of tasteless splendour and magnificence Can eier afford.

WARTON

THis charming geranium, like a melancholy spirit, shuns the light of day; but it enchants those who cultivate it by the delightful perfumes it exhales. 
Oh! there's melody rich in that mournful tone, Though with wo so heavily laden; And I'd rather be sad with thee, my own, Than gay with a happier maiden!

F. S. 0 .

\section{E S A G E.}

I R IS .

\section{Every varying hue}

Of every beautiful thing on earth - the teints Of heaven's own Iris - all are in the west On this delicious eve.

Carrington.

Tris piant is supposed to have been narned after Juno's attendant, because its colours are similar to those bestowed on the messénger of that goddess, by poets and mythological writers.

The various Iris, Juno sends with haste.

Ovid.

Iris is usualiy portrayed as descending from a rainbow; and the eye of heaven (Plutarch says that is the meaning of the ivord Iris) is not more variegated than the flower that has been honoured by her name.

Perchance the gods, like us, conversed with flowers, And Iris, their sweet messenger, did borrow

From the rich wreaths she bore in those bright hours,

Her wings' still varying hues of joy and sorrow:Oh! were she now on earth - how fit to bear

To thee, my goddess, all my love and care! 


\section{ILLUSTRATION OF PIATE.}

\section{Purple and Yellow Iris. - Hawthorn.}

I send jou a message of love on the wings of hope

Fond Love, who lives in my heart for thee, Had a message this morning he wanted to send, While Fear, who will ever beside him be, Cried: "Better beware, my friend !"

But then, sweet Memory woke awhile, And softly she told in Love's true ear, Of a certain bewitching and eloquent smile,

Which you have forgotten, I fear!

Young Hope, who was listening, caught the sound,

All beaming with light, she flew to Love"Oh! round my wings, be your billetdoux bound, And I'll be your carrier-dove!"

'T was done-Hope went-(she knows the way By heart, for she's travelled it oft ere now) Ah! send her back to me, sweet, I pray, With the same unclouded brow'

She will furl, at your feet, her weary wing,

And oh! if the billet she bears be fled,

Think that Fear must have followed and loosened the string -

And jụst guess all that Love would have said. 


\title{
MILD, OR SWEET DISPOSITION.
}

\author{
II A L OW.
}

Who cut up mallows by the bushes, and juniper-roots for their meat. JoB Xxx. 4

Frox the above passage we learn that the mallow was used for food by. those numadic tribes who have always pitched their tents in the desert in preference to dwelling in fixed habitations, where it would have been their duty to cultivate the earth in order to multiply the benefits of nature.

This plant was also eaten, boiled, by the Greeks and Rumans, and in salads, with lettuce and other vegetables; it is still used by the Chinese and the Egyptians.

It grows, naturally, by the rivulet's side; and is of easy culture in any common garden soil. Its appearance is graceful and pleasing; and its rose-coloured flowers harmonize with its leaves and brancises, the whole plant being covered with a silver-coloured silky down. It is equally agreeable to the sight as to the touch. Its flowers, its stalks, its leaves, and its roots, are all useful. We procure from them various juices, sirups, pastilles, and pastes, alitie beneficial to health, and agreeable to the palate. The Romans used it on account of its medicinal qualities

And on that cheek and o'er that brow So soft, so calm, yet eloquent, The smiles that win - the teints that glow But tell of days in goodness spent -

A mind at peace with all below, A heart, whose love is innocent. 


\section{O DES T Y.}

\section{BLUE VIOLET.}

I.ET us entreat our friends who would seek for the purest and most healthy pleasures, to rise with the sun, and accept the invitation of Elliott to

Walk where hawthorns hide

The wonders of the line;

and then - but Howitt, in all his freshness, shall tell you what delights you will meet with:-

"All unexpectedly, in some embowered lane, you are arrested by the delicious odour of violets, those sweetest of Flora's children, which have furnished so many beautiful allusions to the poets, and which are not yet exhausted; they are like true friends, we do not know half their sweetness till they have feit the sunshine of our kindness; and again, they are like the pleasures of our childhood, the earliest and the most beautiful. In May, they are seen in all their glory - blue and whitemodestly peering through their thick-clustering leaves."

Barry Cornwall places the violet before the rose in the following lines. True it is that modesty, of which quality it is the universal emblem, is more to be desired than beauty, but we must ever acknowledge the rose as the queen of flowers.

It has a scent as though Love, for its dower,

Had on it all his odorous arrows tost;

For though the rose has more perfuming power

The violet (haply, 'cause ' $t$ is almost lost, And takes us so much trouble to discover)

Stands first with most, but always with a lover.

It is interesting to notice how widely the violet is distributt $\vec{j}$ over this blooming world. They spring at the foot of the Alps, and bloom on the very summit of the Alleganies;-- their 
sweets are b rne upon the spicy gales of Araby the blest; and they put forth their cerulean flowers in the Persian garden of roses. Humboldt gathered them in the valleys of the Amazon, and on the sides of the lofty Andes. The most lovely flowers are the most simple, and plainly the favourites of nature, for they are the most widely diffused.

It was a thought, as delicate as it was beautiful, which suggested the modest violet as a poetical reward. A golden violet was announced as the prize to be decreed to the author of the best poem in the Provencal language, in 1324.

And in that golden vase was set

The prize - the golden violet.

The Troubanour.

The blossom that blooms in every land, Where laughs a summer-sky blue and bland! As if to tell of that blessed heaven, Whose softest hue to its heart is given!

F. S. 0 .

The violet droops its soft and bashful brow,

But, from its heart, sweet incense fills the air;Sn rich within - so pure without - art thou, IW th modest mien and soul of virtue rare.

F. S. 0 . 


\section{O U R N I G.}

CYPRESS .

The mournful cypress rises round, Tapering from the burial.ground.

LUCAN.

THE cypress is the uriversal emblem of mourning, and is the funeral tree in the Eastern world, from the Persian gulf to the Caspian sea; it is also dedicated to the dead, from Mazanderan to Constantinople, as well as to the utmost bounds of China's fruitful shores.

Ovid gives us a traditionary account of the mournful origin of the cypress-tree, and we always find it devoted to mournful thoughts, or sad solemnities. Cyparissus, son of Telephus of Cea, was beloved by Apollo. Having killed the favourite stag of his friend, he grieved, pined, and, dying, was changed by A pollo into a cypress-tree. Calmet describes it to be a tall, straight tree, having bitter leaves. The shade and smell were said to be dangerous; hence the Romans looked on it as a fatal tree, and made use of it at funerals. It is an evergreen; the wood is heavy, of rather a fragrant smell - is not liable to be attacked by insects, and does not speedily decay. Shakspeare says that cypress is the emblem of mourning; and we are told by Irving that, in Latium, on the decease of any person, a branch of cypress was placed before the door. It is strictly the "sorrowing tree:" nor do we ask with Prior,

Why does the cypress flourish in the shade?

For there is scarcely any poet who does not write of it in mournful sadness. Spenser records it as " the cypress fureral;" and Miss Landon observes,

A funeral train

Will in a cypress-grove be found. 
And again,

The moon is o'er a grove of cypress-trees, Weeping like mourners.

And Byron asks,

Ah! why

With cypress branches hast thou wreathed thy bowers?

Mournful as is the wreath, we find it bestowed, a sad memorial, by the hand of friendship :-

O'er ruined shrines and silent tombs,

The weeping crpress spreads its glooms,

In immortality of wo,

While other shrubs in gladness blow,

And fling uron the passing wind

Their liberal treasures unconfined.

And well its dark and drooping leaf,

May image forth the gloom and grief,

Which, when we parted, gave reply,

From heaving heart and dewy eye :

Then, lady, wear this wreath for me,

Plucked from the faithful cypress-tree.

WIFFEN.

In Turkey, the custom of plantung the cypress-tree over the tombs of derarted friends is still religiously adhered to; and in performing this duty they are careful to select the upright variety, as they suppose it to indicate that the soul of their friend has ascended to the regions of bliss.

Peace to the dust that in silence reposes

Beneath the dark shades of cypress and yew;

Let Spring deck the spot with her earliest roses,

And heaven wash their leaves with its holiest dew.

Pier poitt. 


\section{U S I C.}

\section{REEDS.}

Arcadian pipe, the pastoral reed Of Hermes.

Milton.

PAN, being enamoured of the beautiful Syrinx, pursued her one day to the borders of the river Ladon, in Arcadia. The nymph implored the help of the river, which received her into its waters, and metamorphosed her into reeds. It is recorded that Pan cut several cf these reeds of different sizes, and formed thereof the first shepherd's pipe.

There is a voice, whose tones inspire

Such thrills of rapture through my breast,

I would not hear a seraph-choir, Unless that voice could join the rest.

BYRON.

\section{MY BEST DAYS ARE PAST.}

\section{MIE A D OW-S $\triangle F F R O N$.}

WHEN summer is rapidly departing, this flower, which closely resembles the spriag-saffron, is seen in bloom amid the verdure of our meadows, It is the autumnal colchicum; and though like the spring-saffron in appearance, how unlike in its import! the former brings us joy and hope, while the latter announces the speedy termination of the bright and lovely days of summer. 
The ancients believed that, coming from the fields of Colchis, it owed its birth to some drops of the magic liquor Medea is said to have prepared, in order to restore the aged Eson to the vigour of youth. This fabulous origin led many to suppose, for a long period, that the plant was a sure preservative against all manner of diseases. The Swiss encircle the necks of their children with this flower, and believe that they protect them from every evil. The false opinion of the marvellous virtues of this plant has misled the wisest men; and it required all the experience of Haller to dissipate the vain superstitions of the ignorant.

The flower has neither leaves nor stalks. A long tube, white as ivory, is its only support; the flowers die off in October, and leave no external appearance of seeds. "These lie buried all the winter within the bulb; in spring they grow up on a fruit-stalk, and are ripe about the time of hay-harvest." - "As this plant blossoms late in the year, and probably would not have time to ripen its seeds before winter, Providence has so framed its structure, that it may be performed at a. depth within the earth, out of the reach of the usual effects of frost; and as seeds buried at such a depth are known not to vegetate, a no less admirable provision is made to raise them above the surfacc when they are perfected, and to sow them at a proper season." It thus mingles its fruits with the flowers of spring; and its flowers with the fruits of autumn; at all times the lambs shun it, and the young shepherdess becomes melancholy at the sight of it: so the melancholy-hearted oft weaves a wreath of its pale blue flowers, consecrating it to the memory of happy days which have fled to return no more.

Let fate do her worst, there are relics of joy, Bright dreams of the past, which she cannot destroy; Which come in the night-time of sorrow and care, And bring back the features that joy used to wear. MOORE. 
MY REGRETS FOLLOW YOU TO THE G R A V E.

\section{ASPHODEL.}

THE yellow and white species of this elegant plant arc of very easy culture, and increase rapidly. The latter species covers immense tracts of land in Apulia, and affords very good nourishment to the sheep.

It was sacred to Proserpine, and anciently used in funeral ceremonies; and it was believed that, beyond the Acheron, the shades of the departed walked in vast meadows of Asphodel, where they drank the waters of oblivion.

Bright be the place of thy soul !

No lovelier spirit than thine

E'er burst from its mortal control,

In the orbs of the blessed to shine.

On earth thou wert all but divine,

As thy soul shall immortally be;

An! our sorrows may cease to repine,

When we know that thy God is with thee.

BYsicN, 


\section{I R T H.}

BROOM.

'T was that delightful season, when the broom

Full-flowered, and visible on every steep,

Along the copses runs in veins of gold.

WORDSWORTR.

"Ture broom," says Mr. Martyn, "converts the most barren spot into an odoriferous garden." Wordsworth notices it in the following natural and beautiful lines:-

On me such beauty summer pours,

That I am covered o'er with flowers;

And when the frost is in the sky

My branches are so fresh and gay,

That you might look at me and say,

This plant can never die.

The butterfy, all green and gold,

To me hath often flown,

Here in my blossoms to behold

Wings lovely as his own.

Burns introduces the yellow broom in his "Caledonia :" -

Their groves of sweet myrtle let foreign lands reckion, Where bright-beaming sumners exalt the perfume;

Far dearer to me yon lone glen o' green breckan, Wi' the burn stealing under the lang yellow broom.

It is said that when Linnæus came to England, in 1736, he was so much delighted with the golden bloom of the furze, which he saw for the first time on the commons near London, that he fell on his knees enraptured at the sight.

The Spanish broom is cultivated with us for the beauty and perfume of its flowers. It approaches nearer to the size of a tree than a shrub, and continuing in blossom from July to October, 
it is a great enlivener of our gardens, which, at the latter season, are jut scantily provided with gay flowers.

Cowper has, with many other fine plants, also noticed the broom:-

Hypericum, all bloom, so thick a swarm

of flowers, like flies, clothing her slender rods,

That scarce a leaf appears; mezereon too,

Though leafless, well attired, and thick beset

With blushing wreaths, investing every spray,

Althea, with the purple eye; the broom,

Yellow and bright, as bullion unalloyed,

Her blossoms.

Sweet blooms genista in the myrtle shade.

DARWIS.

Joy, like the zephyr,

That flies o'er the flower,

Rippling it into

Fresh fairness each hour-

Joy has waved o'er thee

His sun-woven wing,

And dimpled thy cheek,

Like the roses of spring.

F. S. $\cap$

\section{O R N A M E N T.}

HORNBEAM.

THE French have made this plant the emblem of ornament, from the splendid effect produced by its judicious training in the 
hands of De Notre, in the gardens of Versailles. These gardens," says Mr. Philips, "which cost Louis the Fourteenth between eight and nine hundred thousand pounds stering, are well calculated to display courtly pomp, and that kind of magnificent revelry, which this monarch indulged in. But to us this heavy grandeur appears more gloomy than the thickest forest, except when the alleys and walks are crowded with company, and the waterworks are in full action. Then every beholder must be struck with the splendour of the scene, which the dress of the French ladies is particularly calculated to improve; for the gayety of their costume relieves the sombre appearance of the trained hornbeam and clipped elm. Their light gauze, gay ribands, feathers, and flowers, substitute blossoms; for, while one seems to display a basket of ruses on her heau, oihers carry nodding thyrsuses of lilac, or waving laburnum; and with the mixture of poppies, nasturtiums, and sunHowers, with which they are bedecked, you forget that the trees are without blossom, for here you see the gay ranks of scarlet soldiers, and there files of green elms; here wave the winged leaves of the acacia, there bows the no less pliable head of the courtier; here dances the jet-d'eau in air, there drops to the earth the well-taught courtesying belle; here monsters spout out water to cool the air, while flattery as abundantly sends forth her streams to refresh the vain. In one spot we see the proud officer flaunting round the brazen image of Venus, while the opposite angle shows the sentimental dame reclining on the pedestal of Mars, or Jupiter. Agricola, a German author, says this scene gave him a foretaste of Paradise."

She binds not her luxuriant hair

With dazzling gem or costly plume, But gayly wreaths a rosebud there,

To match her maiden-bloom.

F. 8. 0 . 


\section{ORACLE.}

DANDELION.

Linveus has given the dandelion a deserved place in the horologe of Flora. It is one of the plants that may be most certainly depended upon as to the hour of opening and closing its flowers.

The flower, if we well examine it, we shall discover to be fully as handsome as the fine garden anemone; and it only needs to be as rare, to be prized as much. This plant blossoms early in the spring, and continues through the summer.

\section{Thine full many a pleasing blnom}

of blossoms lost to all perfume ;

Thine the dandelion flowers,

Gilt with dew, like sun with showers.

Clare.

The dandelion flower is used for Love's oracle. If you are separated from the object of your affection, gently detach one of these transparent spheres; each little feather that composes it is charged with a tender thought. Turn toward the spot inhabited by your beloved; blow softly, and every little winged travelier, like a faithful messenger, shall bear your secret homage to her feet. If desirous of knowing whether the object so dear thinks of you now you are absent, blow again, and if there remain one tuft, it is a sign you are not forgotten. But the second charm should be done with care; blow very gently; for at any age, even at that age which is most congenial to love, it is not well for our peace that we should too rudely disperse the pleasing illusions which embellish life.

Miss Landon wrote some very beautiful lines on seeing an illustration of the garden-scene in Goethe's Faust, where Mar 
garet plucks a starlike flower to divine the real sentiments of her lover. They are called, "The Decision of the Flower"

And with scarlet poppies around like a bower, The maiden found her mystic flower; "Now, gentle flower, I pray thee tell If my lover loves me, and loves me well; So may the fall of the morning dew Keep the sun from fading thy tender blue. Now I number the leaves for my lotHe loves not - he loves me - he loves me not -He lores me-yes, thou last leaf, yes I'll pluck thee not, for that last sweet guess ! He loves me !"- "Yes," a dear voice sighed, And her lover stands by Margaret's side.

\section{PARENTAL L O VE.}

\section{CINQUEFOIL.}

In rainy weather, the leaves of this plant incline themselves over its flowers, forming a kind of canopy, or parapluie. It is gratifying to see a tender mother watching with anxious care the unfolding of a beloved daughter's mind and character.

When love rejects and friends forsake, A parent, though his heart may break, From that fond heart will never tear The child, whose last retreat is there. Ellen Fitzarthur. 


\section{PEACE.}

\section{OLIVE.}

To thee the hearens, in thy nativity, Adjudged an olive-branch, and saurel crown, As likely to be blest in peace and war.

SIIAKSPEARE.

THis tree has been selebrated in all ages as the bounteous gift of Heaven, and as the emblem of peace and plenty. I'eace - wisdom - concord - clemency - joy - the graces - have ever been crowned with olive.

The dove sent out of the ark by Noah to ascertain if the waters were assuaged, returned bearing a branch of olive, as a symbol of that rest which Heaven was about to restore to the earth.

The sinner placed a verdant spray

Within her dead child's hand, And turned, in wordless grief, away-

A lost one-barred and banned!

In that fond act were prayer and vow-

Oh! be her guilt forgiven!

Her dovelet bears an olive-bough,

To make her peace with Ileaven.

F. S. 0 . 


\section{PERFECT EX ELLENCE.}

\section{STRAWBERRY.}

Av illustrious French writer conceived the design of compia ling a general history of nature, in imitation of the ancients, and of some moderns. A strawberry-plant, which chanced to grow by his window, dissuaded him from this design. On minutely observing it, he discovered so much to learn and to admire, that he felt convinced that the study of a single plant, with its habits, would suffice to employ the life of many learned men. He therefore abandoned his design, and the ambitious tille he had selected, and gave to his work the simple title, "Studies from Nature." In this book, which is worthy of Pliny or of Plato, we find the best history of the strawberry. This humble plant delights to grow in our woods, and cover their borders with delicious fruil, which is the property of any one who chooses to gather it. It is a charming gift, that Nature has withdrawn from the operation of those laws which render property exclusive: and this she is pleased to bestow on all her chiluren.

The flowers of the strawberry form pretty bouquets; but what barbarous hands would wish to gather them, and so de. stroy the promised fruit? Let us hear IVordsworth's plea for the strawberry-blossom. -

That is a work of waste and ruin -

Do as Charles and I are doing!

Strawberry-ulossoms, one and all, We must spare them-here are many-

Look at it - the flower is small -

Snall and low, though fair as any;

Do not touch it! - summers two

I am older, Anne, than you.

Pull the primrose, sister Anne, Pall as many as you can.

Here are daisies, take your fill;

Pansies and the cuclioo-flower; 
Of the lofty daffodil

Make your bed and make your bower;

Fill your lap and fill your bosom;

Only spare the strawberry-blossom!

Primroses, the spring may love them,

Summer knows but little of them.

Violets, a barren kind,

Withered on the ground must lie ;

Daisies leave no fruit behind,

When the pretty flowerets die:

Pluck them, and another year

As many will be growing here.

God has given a kindlier power

To the favoured strawberry fllower:

When the months of spring are fled,

Hither let us bend our walk;

Lurking berries, ripe and red,

Then will hang on every stalk,

Each within its leafy bower;

And for that promise spare the flower.

It is, however, most delightful to find the fruit of the strawberry, at all seasons of the year, amid the glaciers of the lofty Alps. When the sunburnt traveller, oppressed wi.h fatigue upon those rocks, which are as old as the world, in the midst of those forests, half destroyed by avalanches, he vainly seeks a hut to rest his weary limbs, or a fountain to refresh himself. Unexpectedly, he sees, emerging from the midst of the rocks, troops of young girls who advance toward him with baskets of perfumed strawberries; they appear on all the heights above, and in every dell below. It seems as though each rock and each tree were kept by one of these nymphs, as placed by Tasso at the gate of the enchanted gardens of Armida. As seducing, though less dangerous, the young Swiss peasants, in offering their charming baskets to the traveller, instead of retarding his progress, give him strength to pursue his journey. The strawberry has the property of not undergoing the acetous fermentation in the stomach. The learned Linnæus was cured of 
frequent attacks of gout by the use of strawberries. This fruit, it is said, has often restored to health patients given over by every physician. They will compose a thousand delicious sherbets; they are the delight of our tables, and the luxury of our rural feasts. Everywhere these charming berries, which dispute in freshness and in perfume the buds of the n'ost beautiful flowers, please the sight, the taste, and the smell. Yet, there are some unfortunate enough to hate strawberries, and to swoon at the sight of a rose. Ought it to astonish us since we see certain persons grow pale at the relation of a guod action, as if the inspiration of virtue were a reproach to them! Happily, these sad exceptions take nothing from the charm of virtue from the beauty of the rose - nor from the perfect excellence of the most charming of fruits.

But rixtue bruised exhales a purer breath, Sighs fragrance forth, and triumphs over death.

PhILlips.

\section{PER I D Y.}

\section{ALIOND LAUREL.}

IN the environs of Trebizond, on the borders of the Black sea, we find the treacherous laurel growing naturally. It conceals under its sweet and brilliant verdure the most deadly poison we are acquainted with. In winter it adorns our groves; and is loaded in the spring with numerous pyramids of white flowers, which are succeeded by a black fruit, resembling small cherries; its flowers, fruit, and leaves, have the taste and smell of the almond. It is related that a tender mother, on the birthday of one of her children, wishing to prepare something 
nice for her family, threw some pounds of sugar and a handful of almond laurel leaves into a caldron of boiling milk. At the prospect of the approaching feast, an innocent joy sparkled in every eye. O surprise! Scarcely had they tasted the fatal dish, when every countenance changed, their hair became erect, their breathing quickened, a thousand confused noises issued from their chests, a horrible fury possessed, agitated, and disordered their senses. The desolate mother wished to call for succour; but, seized with the same disease, she partonk of the unsensible delirium, for which she could offer no remedy. Calm sleep at length relieved them from this sad inebriation. But what were the feelings of the poor mother, when informed on the morrow, that she had given to her children a poison like that of the viper! This poison, concentrated in the distilled water or the essential oil of the almond laurel, is so violent, that it is sufficient, when it comes in contact with the slightest wound, to kill the most robust man. The sale of this deadly poison is strictly forbidden in Italy; yet, notwithstanding, some greedy distillers have sold it under the name of extract of bitter almond. We should therefore caution all persons against its use. It was formerly much used to give a flavour to puddings, custards, \&c.; but this practice is much less frequent siace it has been ascertained to be so poisonous in its effects.

Though my many faults defaced me, Could no other arm be found, Than the one which once embraced me, To inflict a cureless wound?

BTRON 


\section{PLEASURE WITHOUT ALLOY.}

MOSS-ROSE.

The rose that hails the morning,

Arrayed in all its sweets,

Its mossy couch adorning,

The sun enamoured meets.

THE elegant moss-rose is commonly supposed to be the offspring of the Provence rose, though some consider it to belong to the family of hundred-leaved roses. It has ever been made the emblem of perfect joy; Milton mentions it as

Without thorn, the rose;

And an anonymous writer has sung of it in that character.-

Oh! I love the sweet-blooming, the pretty moss-rose,

' $T$ is the type of true pleasure, and perfected joy ;

Oh! I envy each insect that dares to repose

'Mid its leares, or among its soft beauties to toy.

I love the sweet lily, so pure and so pale,

With a bosom as fair as the new.fallen snows;

Her luxuriani odours she spreads through the vale,

Yet 'e'en she must yield to my pretty moss-rose.

Oh! I love the gay heart's-ease, and violet blue,

The sunflower and bluebell, each floweret that blows,

The fir-tree, the pine-tree, acacia, and yew,

Yet e'en these must yield to my pretty moss-rose.

Yes, I love my moss-rose, for it ne'er had a thorn,

'T is the type of life's pleasures, unmixed with its woes;

' $T$ is more gay, and more bright, than the opening morn -

Yes, all things must yield to my pretty moss-rose. 


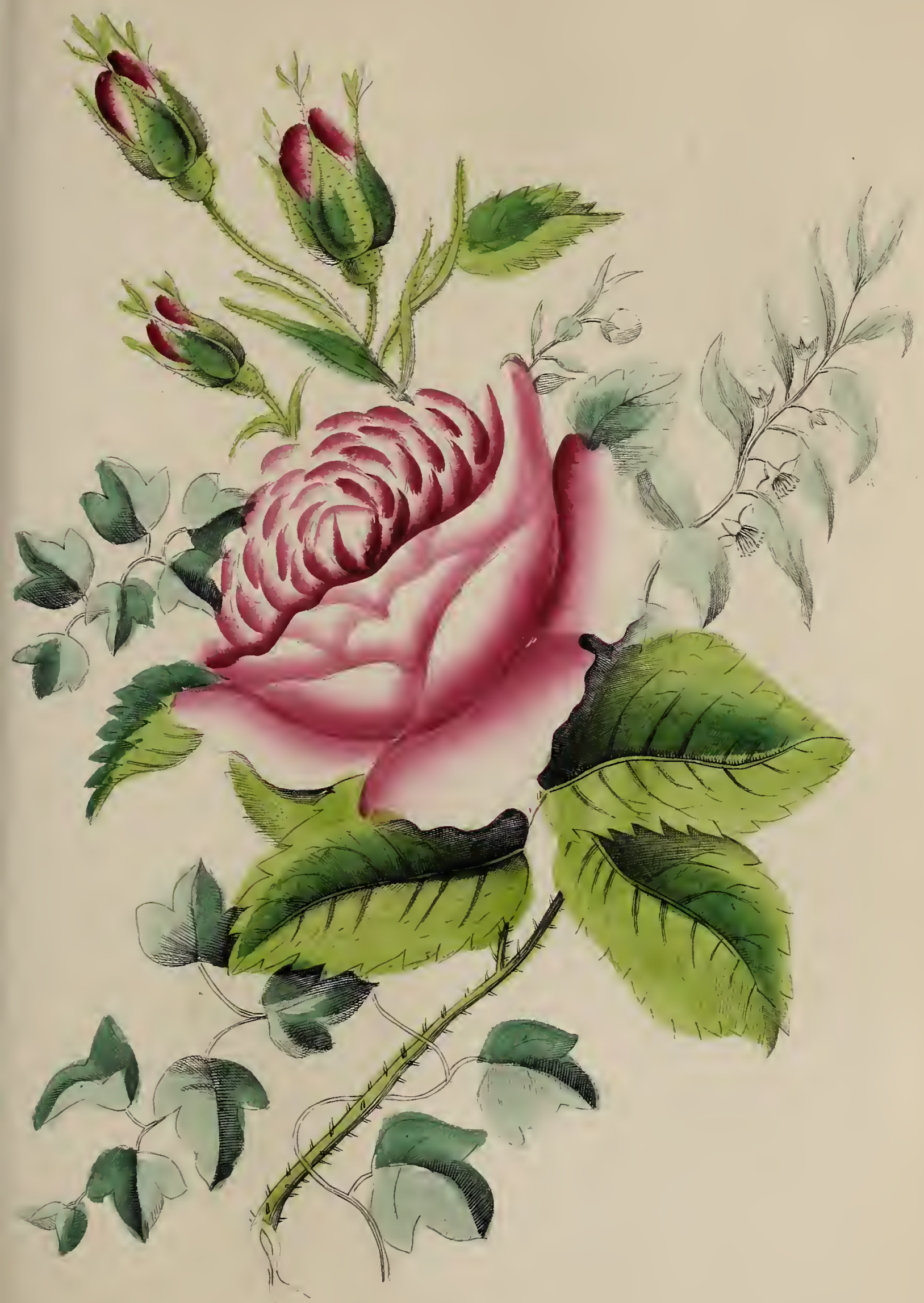





\section{PLATONIC LOVE.}

\section{ACACIA.}

The savages of America have consecrated the acacia to the genius of chaste love; their bows are made from the incorruptible wood of this tree, their arrows are armed with one of its thorns. These fierce children of the desert, whom nothing can subdue, conceive a sentiment full of delıcacy; perhaps what they are unable to express by words, but they understand the sentiment by the expression of a branch of blooming acacia. The young savage, like the city coquette, understands this seducing language, and receives, blushing, the homage of him who has won her heart by respect and by love.

It is not more than a century since the forests of Canada yielded us this beautiful tree. The botanist Robin, who first brought it us, gave it his name. The acacia, when spreading its light shade in our groves, with its scented flowers, and sweet and fresh verdure, seems to prolong the spring. The nightingale loves 10 confide its nest to this new inhabitant of our climate; the lovely bird, assured by the long and strong thorns which protect its family, sometimes descends upon the lowest branches of the tree, to make its ravishing notes the better heard.

The acacia has been made the emblem of domestic beauty by an anonymous writer, who thus speaks of it: "Teints of the white, the golden, and the red rose, are beautifully intermingied with the rich blossoms of the acacia. It is found in the most retired places, and it blooms the fairest in the closeness of its own foliage. It loves the mossy rock and the solitary grove, and pines away in the gay garden and crowded parterre. Nourmahal sings:-

Our rocks are rough, but smiling there

The acacia waves her yellow hair, 
Lonely and sweet, nor loved the less

For flowering in a wilderness :

Then come, thy Arab maid will be

The loved and lone acacia-tree.

There could be no fitter emblem of a beautiful woman flourishing in the retirement of her home, secluded from the vanities of 'crowded life,' and adorning with her bloom the abode of domestic affection."

They know not my heart who believe there can be One stain of this earth in its feelings for thee; Who think, while I see thee, in beauty's young hour, As pure as the morning's first dew on the flower, I could harm what I love - as the sun's wanton ray But smiles on the dewdrop to waste it away!

MOORE.

\section{POE T R Y.}

EGLANTINE, OR SWEET-BRIER.

O'er-canopied with luscious woodbine, With sweet musk-roses, and with eglantine.

BhaKSPEARE.

Tre eglantine or wild-brier rose, more commonly called sweetbrier, has ever been considered the poet's flower. It is not loved for its fair delicate blwsoms only; but its fragrant leaves, which perfume the breez if dewy morm, and the soft breath 
of eve, entitle it to its frequent association with the woodbine or honeysuckle.

Its sides I'll plant with dew-sweet eglantine, And honcysuckles full of clear bee wine.

KEATS.

Yonder is a girl who lingers

Where wild honeysuckle grows,

Mingled with tho brier-rose.

H. Smith.

Burns says: "I have some favourite flowers in spring, among which are the mountain-daisy, the harebell, the wild-brier rose, the budding birch, and the hoary hawthorn."

We eye the rose upon the brier, Unmindful that the storm is near.

The fragrance exhaled by the sweet-brier, especially after a gentle shower, is so agreeable and refreshing, that we do not think it can be too thickly planted amid our plantations and thickets. Dryden, from Chaucer, thus celebrates its delightful fragrance:-

A sweeter spot on earth was never found, I looked, and looked, and still with new delight; Such joy my soul, such pleasures filled my sight; And the fresh eglantine exhaled a breath, Whose odours were of power to raise from death.

The world is full of poetry - the air Is living with its spirit; and the waves Dance to the music of its melodies, And sparkle in its brightness.

Percivat. 
PREFEREN E E.

\author{
A P PLE-BLOSSON.
}

What virgin's check

Can match this apple-bloom?

Elliott.

What is more enchanting to the lover of nature than the apple-tree, when clad with its beautiful bloom in the early spring? and the more, that they hold forth the promise of an abundance of delicious fruit. The apple-bloom is indeed a charming flower, and by some is preferred before the rose.

'I he idol I have set apart to worship -

Watched over - cherished - mused upon in absence, Until my full heart ached with tenderness!

F. S. 0 . 
A ND FLOWERS OF POETRY.

ILLUSTRATION OF PLATE.

$$
\text { Blue Violet._Daisy. - Apple-Blossom. }
$$

Your modesty and innocence secure you the preference.

IF regal sceptre, love, were mine; -

Or I possessed the realms of faery,

This faithful heart would still be thine,

My innocent and modest Mary!

Young Beauty, at my feet threw down

A rose, with rare and tempting offers;-

And Rank, unclasped her radiant crown;--

And Wealth unlocked her loaded coffers:-

But Beauty's roses soon must fly;

And Love with Rank and Wealth is wary; Thy purer charms can never die,

My innocent and modest Mary!

F. S. 2. 
PREFERENCE.

ROSE-SCENTED GERANIUII.

OF the geranium there are many species; some drooping, others briliant, some perfumed, and others again inodorous. That which emits a roselike odour, is distinguished by the softness of its leaves. its sweet odour, and the beauty of its purple flowers.

No wonder that cheek, in its teinting transcendent, Excelleth the beauty of others by far; No wonder that eye is so richly resplendent Your heart is a rose, and your soul is a star!

Then give back to heaven the light it bestows, Till the star smile again in its birthplace above; But oh! let me share the soft bloom of the rose, Yield, yield the warm heart to my cherishing love! F. S. 0

\section{P R E A G E.}

SMALI CAPE IIRYGOLD.

The French have named this flower souci pluviatile, and in England it is distinguished by the name of pluvialis, because of its flowers closing on the approich of rain. It constantly opens at seven o'clock in the morning, and remains so till four in the evening, if the weather be dry. If it does not spen, or 
if it closes before the usual hour, we may be sure that there will be rain ere nightfall.

Your lips are like the prophet-flower;-

When thus they, quivering, close, my love;

We're sure to have a summer-shower,

From the blue eyes that beam above.

F. S. 0 .

\section{PRETENSION.}

WILLOW-HERB.

'T'HIs beautiful plant, which flourishes by the water's side, seems to take pleasure in admiring itself in the crystal stream. For this reason it is compared to a vain woman, proud of her own charms. Mr. Loudon says that it is a thriving plant, and will grow anywhere, under the drip of trees, and in smoky cities, parks, \&c., and is very showy when in flower.

Some women deify a friend -

Some grovel at the shrine of pelf-

A. few to Heaven in worship bend-

Her idol is - her own sweet self!

F. S. D. 


\section{P R O H I B T I O N.}

\section{PRIVET.}

THrs shrub is one of the prettiest ornaments of our hedgerows. Its spike-formed thyrsi of white monopetalous flowers, which in shape resemble those of the lilac in miniature, agreeably perfume the hedges during the months of May and June; while its deep purple shining berries garnish the spray of this shrub during the whole winter, affording food to the bullfinch and thrush, and a

Fit dwelling for the feathered throng, Who pay their quit-rents with a song.

Green.

"Why," said a young mother of a family to the pastor of the village, "did you not plant a strong palisade of thorns in the place of this hedge of flowering privet which surrounds your garden?" The pastor replied: "When you prohibit your son from joining in dangerous pleasures, the prohibition issues from your lips with a tender smile; your look caresses him ; and, if he murmur, your maternal hand offers him a toy to console him; so the pastor's hedge ought not to injure, but while it keeps off those who would intrude, it should offer flowers tisough it repels them."

So soft is her sigh and so sweet is her smile, Even though she prohibits our pleasure the whileThat pleasure is robbed of its charm by her voice, And e'en in her chiding we learn to rejoice.

F. S. 0 . 


\section{PRUDENCE.}

\section{SERVICE-TREE.}

October is drawn in a garment of yellow and carnation; in his left hanl a basket of serrices, medlars, and other fruits that ripen 'ate.

PEACHAM.

EVERY tree and every plant has a physiognomy which is proper to itself, and which seem to give it a character. The giddy almond-tree prc.usely puts forth its flowers in spring, at the risk of having no fruit for the autumn, while the servicetree never bears fruit until it has acquired full strength, and then its harvest is certain. For this reason it is made the emblem of prudence. This beautiful tree retains is dazzling scarlet fruit throughout the winter; when we see it shining a brilliant contrast to the white mantle of snow which covers the earth. Its harvest can only be gathered in winter, and for that season Providence has reserved it for the use of the smaller birds.

Beware of desperate steps! - the darkest day,

Live till to-morrow, will have passed away.

COWPER.

\section{PEERLESS AND PROUD.}

\section{IAGNOLIA.}

" $\mathrm{O} F$ this splendid family of trees the American continent has many species. They are distinguished by their rich, smooth foliage, large, fragrant flowers, and aromatic bark. Some of 
them are of very exalted stature, taking rank with the lighesi tenants of the wood." In the southern states, whole groves of the magnificent magnolia grandiflora are found scenting the air for miles around, with their rich and delicious fragrance. The large whiteleaf of the flower often serves the rumantic southern youth for paper. He pricks upon it with a needle or pin the passionate thoughts of his heart, and commits his perfumed billetdoux to the care of zephyr to be wafted to the feet of his ladye-love.

\section{THE SOUTHERNER TO A TANKEE.}

What! write a burning billetdoux

On common colored paper,

And melt the wax to seal it, too,

Within a tallow taper!

Not thus we woo our Georgian girls,

They'd scorn so poor a letter;

They'd twist with it their silken curls,

And bid us write a better.

We seek a sweeter, purer leaf,

To bear our passion to them;

Our vows are beautiful as brief; -

I'll tell you how we woo them.

Deep in our southern forest-glooms,

Our tempests prouady braving,

The pure magnolia richly blooms,

Its peerless blossoms waving. 
We pluck the leaf of perfumed snow,

We trace love-verses on it,

And as the quick thoughts breathe and glow,

The flower makes sweet the sonnet!

We tell the maid it mocks, in hue,

Her fair and virgin foreheaà;

We say her lips' delicious dew

The blossom's balm has borrowed.

Our sweet appeal, in secret bower,

We bid her con apart,

And trace it on as fair a flower,

Her own unsullied heart.

'T is writ with plumes from Cupid's wing -

With passion's kiss we seal it,

Then free to Zephyr's care we fling

Our light and blooming billet!

Well guarded from blockade and breach,

Must be that heart unsleeping,

Such fragrant vows would fail to reach,

Or fail, when reached, in keeping!

F. 8. 0. 


\section{PURITY AND MIODESTY.}

\section{WHITE LILY.}

Ye loftier lilies, bathed in morning's dew of purity and innocence, renew Each lovely thought.

Banton.

ThIs delicate and beautiful flower has for centuries received its tribute of admiration from the lovers of nature. Who has not felt a glow of delight in perusing that gorgeous ciescription of the lily which Christ himself gave to his disciples? "Of all the poetry ever drawn from flowers, none is so beautiful, none is so sublime, none is so imbued with that very spirit in which they were made, as that of our Lord: 'And why take ye thought for raiment? Consider the lilies of the field, how they grow; they toil not, neither do they spin; and yet $I$ say un to you, that even Solomon, in all his giory, was not arrayed like one of these. Wherefore, if God so clothe the grass of the field, which to-day is, and to-morrow is cast into the oven, shall he not much more clothe you, O ye of little faith!" The sentiment built upon this entire dependance on the goodness of the Creator, is one of the lights of our existence, and could only have been uttered by Christ; but we have here also the expression of the very spirit of beauty in which flowers were created - a spirit so boundless and overflowing, that it delights to enliven and adorn with these riant creatures of sunshine the solitary places of the earth; to scatter them by myriads over the very desert 'where no man is, on the wilderness where there is no man;' sending rain 'to satisfy the desolate and waste ground, and to cause the bud of the tender herb to sprinis furth." "

It is generally admitted that the white lily is a native of Palestine. The heathen nations consecrated it to Juno, contending by their fable that it sprang from the milk of that goddess; 
as we read that Jupiter, being desirous of raising Hercules to the rank of a divinity, induced Juno to drink deep of a cup of nectar, which threw the queen of the gods into a profound sleep. Jupiter placed Hercules at her sreast, that the divine milk might enter his frame, and thus work his irnmortality. The infant was not able to swallow so rapidly as he drew the milk from her celestial breast, some drops of which fa!ling on the earth, this flower sprang up from it; hence it has been called Juno's rose.

In the Hebrew language the name Susannah signifies a lily; and all nations agree in considering it the symbol of purity and modesty.

How withered, perished, seems the form

Of yon obscure unsightly root;

Yet from the blight of wintry storm

It hides secure the precicus fruit.

The careless eye can find no grace,

No beauty, in the scaly folds,

Nor see within the dark embrace

What latent loveliness it holds.

Yet in that bulb, those sapless scales,

The lily wraps her silver vest,

Till vernal suns and vernal gales

Shall kiss once more her fragrant breast.

Yes, hide beneath the mouldering heap,

The undelighting slighted thing;

There, in the cold earth, buried deep,

In silence let it wait the spring. 
Oh ! many a stormy night shall close

In gloom upon the barren earth, While still, in undisturbed repose, Uninjured lies the future birth;

And Ignorance, with skeptic eye,

Hope's patient smile shall wondering view Or mock her fond credulity, As her soft tears the spot bedew.

Sweet smile of hope, delicious tear. The sun, the shower indeed shall come; The promised verdant shoot appear, And Nature bid her blossoms bloom.

And thou, $O$ virgin queen of spring !

Shalt, from thy dark and lowly bed, Bursting thy green shade's silken string, Unveil thy charms, and perfume shed;

Unfold thy robes of purest white, Unsullied from thy darksome grave, And thy soft petals' silvery light - In the mild breeze unfettered wave.

So Faith shall seek the lowly dust Where humble sorrow loves to lie, And bid her thus her hopes intrust, And watch with patient, cheerful eye; 
And bear the long, cold, wintry night, And bear her own degraded doum, And wait till heaven's reviving light, Eternal spring! shall burst the gloom. Mrs. Henry Tighe.

\section{RARITY.}

II ANDRAKE.

THE ancients attributed great virtues to this plant; but as they rave not left any accurate description of it, we are ignorant what species they gave that name to. Our charlatans and mountebanks, profiting by the ignorance of the people, frequently made different roots in to the form of a little man, which they exhibited to the credulous, and sought to persuade them that these marvellous roots were the true mandrake, which are found only in one quarter of China, nearly inaccessible. They added that these mandrakes uttered the most lamentable cries, closely resembling those of a human being, when their leaves were plucked after the night-dew had descended; and that whosoever ventured to do it, was struck by death :-

The phantom torms-oh! touch them not, That appal the murderer's sight;

Lurk in the fleshy mandrake's stem, That shriek when torn at night. 


\section{RE C O N I L I A T ION.}

\section{HAZEL.}

Why sit we not beneath the grateful shade, Whirh hazels, intermixed with elms, have made?

DRYDEN.

THERE was a time when men were not united by any common tie. When the mother would deprive her son of the wild fruic with which he wished to appease his hunger, and if misfortune united them for a moment, the sudden sight of an oak laden with acorns, or a beech covered with beech-mast, rendered them enemies. At that period the earth was filled with horror; there was no law, no religion, no language; man was utterly ignorant of his nature - his reason slept, and he was often seen more cruel than the ferocious beasts whose frightful howling he imilated.

sccording to ancient mythology, the gods had pity on the human race. Apollo and Mercury exchanged presents, and came down upon the earth. The grod of harmony received from the son of Maia a tortoise-shell, of which he had made a lyre, and gave in return a branch of hazel, which had the power of making virtue beloved, and of reuniting hearts divided by hatred ana envy. Thus armed, the iwo sons of Jupiter presented themselves to men. Apollo first sang that eternal Wisdom which had created the universe; he told how the elements were produced, and how every part of nature was united by the sweet bonds of love; and, finally, he taught men that they should appease the anger of the gods by adoration and praise. At his voice, pale and trembling mothers were seen advancing wi, their little children in their arms; hunger was suspended, and the thirst for vengeance fled from every heart. Then Mercury touched mankind with the wand Apollo had given to hil.. He loosened their tongues, and taught them to express their thoughts by words: he afterward told them that union 
made strength, and that nothing could be derived from the earth without mutual labours. Filial piety and patriotic love were brought into action, by his eloquence, to unite the human race; and commerce he made the bond of the world. His last thought was the most sublime, for it was consecrated to the gods; and he told mankind that they might become equal with the gorls by deeds of love and beneficence.

Ornamented with two light wings, and serpents entwining themselves around it, the hazel-wand, presented to the god of eloquence by the god of harmony, is still, under the name of Mercury's wand, the symbol of peace, commerce, and reconciliation.

As letters some hand hath invisibly traced,

When held to the flame, will steal out on the sight,

So many a feeling that long seemed effaced,

The warmth of a meeting like this brings to light.

Moore.

R E S E R V E.

IAPIE.

THE maple is made the emblem of reserve, because it 3 flowers are very slow in opening, and also fall with extreme tardiness. Hanbury observes, that when the flowers, which are of a fine yellow colour, are out in the spring, the tree has great beauty; and in the autumn, the leaves die to a golden yellow hue, which produces a good effect when the various teints of the fading vegetable world are so universally displayed. 
If her feelings, those buds of the heart, Are slow their soft petals to part-

Too timid to brook

The world's cold look;

And dreading the slanderer's dart;-

When once they unfold in perfume,

They glow like the warm golden blcom

Which the maple-tree shows,

When its blossorns unclose,

Like light in the deep forest-gloom.

F. S. O.

\section{RESOLVE THE RIDDLE.}

\section{TREMELLA NOSTOC.}

THE tremella is a gelatinous plant, which has occupied much of the naturalist's attention, but as yet it has baffled research. It was very celebrated among the alchymists of old, who used it in the preparation of the philosopher's stone and universal panace a, considering it as a fallen star. It seems, however, to render research fruitless, by being continually found in various analogous forms, which again resume their previous appearance. They are generally found in the alleys of gardens, and in moist pasture; and sometimes, after a wet and rainy night, the earth in the thickets of the Tuileries has been observed to be enturely covered. A few hours after sunrise they entirely disappear. In short, we know nothing certain about this singular plant: it is a secret of naturo which resists our most persevering inquiries. 
You say that my heart is a riddle to you; -

Do you take enough interest in it,

To find out its meaning ?,- for oh! if you do,

As your proper reward, you shall win it!

F. S. 0 .

\section{RETURN OF HAPPINESS.}

\section{LILY OF THE VALLEY.}

Sweet flower o' the valley, wi' blossoms of snow, And green leaves that turn the cauld blast frae their stems; Bright emblem o' innocence, thy beauties I lo'e, Aboon the king's coronet circled wi' gems!

There's no tinsel about thee, to make thee mair bright,

Sweet lily! thy loveliness a' is thine ain, And thy bonnie bells, danglin' sae pure and sae light,

Proclaim thee the fairest o' Flora's bright train.

Turs lowly plant loves the shelter of the hollow valleys, the shade of oaks, or the cool banks of streams.

The lily, screened from every ruder gale,

Courts not the cultured spot where roses spring.

OGILVIE.

In the earliest days of May its snowy flowers expand them. selves; and scatter their perfume in the air. Barton says :-

The lily, whose sweet beauties seem As if they must be sought.

And Thomson gives us a glimpse of a "fair and bonnie spor," where fairies might hold their revels :- 
Seek the bank where flowering elders crowd, Where, scattered wide, the lily of the vale Its balmy essence breathes, where cowslips hang The dewy head, where purple violets lurk, With all the lovely children of the shade.

Wordsworth, who delights to wander amid the green and Howery fields, to explore the valley, or scale the mountain's loftiest height, has not forgotten this sweet flower:-

That shy plant, the lily of the vale,

That loves the ground, and from the sun withholds

Her pensive beauty, from the breeze her sweets.

And at this season the nightingale seeks its consort in the depths of the forests, where the echo in the solitude answers to bis voice. Guided by the perfume of the lily of the valley, this charming bird chooses its retreat. There it celebrates, in its melodious song, the delights of solitude and of love; and the flower which every successive year announces to him the return of happiness.

The "Naiad-like lily of the vale, whose tremulous bells are seen through their pavilions of tender green," should form a part of every wreath that crowns the happy, the innocent, and the gay.

Blest meeting, after many a day Of widowhood passed far away, When the loved face again is seen, Close - close - with not a tear between Confidings frank, without control, Poured mutually from soul to soul; As free from any fear or doubt, As is that light from chill or stain, The sun into the stars sheds out, To be by them shed back again! 
AND FLOWERS OF POETRY.

ILLUSTRATION OF PLATE.

Crswn Imperial and Turk's Cap Lilies. - Lily of the Valley.

You have the power to restore me to happiness.

Will you say no, dear,

When soft and low, dear,

Love pleads for love, which you only can give?

Will you then fly me?

Can you deny me?

One little "yes" would allow me to live.

Care hovers o'er me,

Clouds, wild and storny,

Darken before me-but one smile of thine,

Through sorrow's haze, love,

Softly can raise, love,

Hope's sunny rainbow - bright and benign!

F. S. ก. 


\section{REW AR D OF VIR TUE.}

A GARLAND OF ROSES.

Let us crown ourselves with roses ere they be withered.

Solonion's Sowg.

At Salency, in France, there is a festival of roses, instituted by St. Medard, bishop of Noyon. There is an annual assemblage of young persons of both sexes, who elect for their queen of the day that maiden who is most worthy (and her worth must consist in the practice of social and domestic virtues); then they crown her amid loud rejoicings, and with solemn ceremony. The simple splendour of those flowers, which are the crown of innocence, is at once its reward, encouragement, and emblem. It is a gentle ambition, whose utmost aim is a garland of roses.

Roses seem to have been used in garlands among the ancient Egyptians; for we read that when Ptolemy and Cleopatra entertained Cesar, and the suble Romans who attended him did

With wreaths of nard the guests the ir temples bind, And blooming roses of immortal kin !.

ROWE'S LUCAN.

Yes! thou shalt wear

The wreath we are merrily braiding,

Of buds and blooms -

The beautiful roses of spring.

Amid the hair,

Thy forehead of snow o'ershadowing,

'T will mock the blush,

That steals to thy cheek as we sing! 
ANO LOWERS OF POETRY.

For thee we twine -

For who could so gracefully wear it,

As she, whose heart

Is lovely and pure as the rose?

The wreath is thine-

And the happiness - each of us share it,

For thou art so meek,

No envy can mar thy repose!

F. S. 0 .

\section{R I C H E S.}

CORN.

WE are assured by botanists that corn is nowhere found in its primitive state. It seems to have been confided by Providence to the care of man, with the use of fire, to secure to him the sceptre of the earth. With corn and with fire, all other gifts may be dispensed with or acquired. With corn alone we could nourish every domestic animal which affords flesh for our sustenance, shares our labours, and is in various ways serviceable to us. The pig, the hen, the duck, the pigeon, the ass, the sheep, the goat, the horse, the cow, the cat, and the dog; each renders him something in return for his care. We receive from each, according to nature, either eggs or milk, bacon or wool, various meats, or services. Corn is the first bond of society, because its culture and preparation for our use require great labour and reciprocal services. From its inest mable value, the ancients called the good Ceres the legislatrix.

There are occasions when food is much more highly esteemed than the possession of riches. An Arab, wandering in the desert, had not tasted food for the space of two days, and saw 
that he had reason to apprehend famine. In passing near a well, where the caravans stopped, he perceived a little sack on the sand. He took it up, saying, "God be praised, it is, I think, a little flour." He hastened to open the sack, but at the sight of its contents, he cried, "How unfortunate I am! it is only some gold powder!"

We shall extract from that delightful work, Howitt's "Book of the Seasons," a slight sketch of the harvest in England. "The harvest is a time for universal gladness of the heart. Nature has completed her most important operations. She has ripened her best fruits, and a thousand hands are ready to reap them with joy. It is a gladdening sight to stand upon some eminence, and behold the yellow hues of harvest amid the dark relief of hedges and trees, to see the shocks standing thickly in a land of peace; the partly-reaped fields and the clear cloudless sky shedding over all its lustre. There is a solemn splendour, a mellowness and maturity of beauty, thrown over the landscape. The wheat-crops shine on the hills and slopes, as Wordsworth expresses it, 'like golden shields cast down from the sun.' For the lovers of solitary rambles, for all who desire to feel the pleasures of a thankful heart, and to participate in the happiness of the simple and the lowly, now is the time to stroll abroad. They will find beauty and enjoyment spread abundantly before them. They will find the mowers sweeping down the crops of pale barley, every spiked ear of which, so lately looking up bravely at the sun, is now bent downward in a modest and graceful curve, as if abashed at his ardent and incessant gaze. They will find them cutting down the rustling oats, each followed by an attendant rustic who gathers the swath into sheaves from the tender green of the young clover, which, commonly sown with oats to constitute the future crop, is now showing itself luxuriantly. But it is in the wheat-field that all the jollity, and gladness, and picturesqueness, of harvest are concentrated. Wheat is more particularly the food of man. Barley alfords him a wholesome but much-abused potation; the oat is welcome to the homely board of the hardy mountaineers, but wheat is especially and 
everywhere the 'staff of life.' To reap and gather it in, every creature of the hamlet is assembled. The farmer is in the field, like a rural king amid his people:

Around him ply the reaper band

With lightsome heart and eager hand,

And mirth and music cheer the toil,

While sheaves that stud the russet soil,

And sickles gleaming in the sun,

Tell jocund autumn is begun.

"The labourer, old or young, is there to collect what he has sown with toil, and watched in its growth with pride; the dame has left her wheel and her shady cottage, and, with sleevedefended arms, scorns to do less than the best of them; the blooming damsel is there, adding her sunny beauty to that of universal nature; the boy cuts down the stalks which overtop his head; children gleam among the shocks; and even the unwalkable infant sits propped with sheaves, and plays with the stubble, and

With all its twined flowers.

Such groups are often seen in the wheat-field as deserve the immortality of the pencil. There is something, too, about wheat-harvest which carries back the mind and feasts it with the pleasures of antiquity. The sickle is almost the only implement which has descended from the olden times in its pristine simplicity - to the present four, ncither altering its form, nor becoming obsolete, amid all the fis shions and improvements of the world. It is the same now as st was in those scenes of rural beauty which the scripture history, without any laboured description, often by a single stroke, presents so livingly to the imagination, as it was when tender thoughts passed

Through the sad heart of Ruth, when sick for home. She stood in tears amid the aicil corn; 
when the minstrel-king wandered through the solitudes of $\mathrm{Pa}$ ran, or fields reposing at the foot of Carmel; or, ' as it fell on a day, that the child of the good Shunamite went out to his father to the reapers. And he said unto his father, MIy head, my (head! And he said to a lad, Carry him to his nother. And when he had taken him, and brought him to his mother, he sat on her knees till noon, and then died.' (2 Kings, iv. 18-20.) Let no one say it is not a season of happiness to the toiling peasantry; I know that it is. In the days of boyhood I have partaken their harvest labours, and listened to the overflowings of their hearts as they sat amid the sheaves beneath the fine blue sky, or among the rich herbage of some green headland beneath the shade of a tree, while the cool keg plentifully replenished the horn; and sweet after exertion were the contents of the harvest-field basket. I know that the poor harvesters are among the most thankful contemplators of the bounty of Providence, though so little of it falls to their share. To them harvest comes as an-annual festivity. To their heal thful frames, the heat of the open fields, which would oppress the languid and relazed, is but an exhilarating glow. The inspiration of the clear blue sky above, and of scenes of plenty around them; and the very circumstance of their being drawn from their several dwellings at this bright season open their hearts, and give a life to their memories; and many an anecdote and history from 'the simple annals of the poor,' are there related, which need only to pass through the mind of a Wordsworth or a Crabbe, to become immortal in their mirth or wo."

She had passed through the shadow and sunlight of Life, She had learned, in its storms, to exult and enaure, And her gentle reply, with sweet wisdom, was rife "To me-there are none in the universe poor!"

F. S. 0 . 


\section{SA D N S S.}

\section{DEAD LEAVES.}

As winter advances, the trees lose their verdure, after being despoiled of their fruits. The "fall of the leaf" is a pleasing period to all who love the study of nature, and seek to derive profit therefrom. James Montgomery has sung the falling leaf, and the lines contain sentiments so just that we introduce them here for the delight of our readers :-

Were I a trembling leaf

On yonder stately tree,

After a season, gay and brief,

Condemned to fade and flee;

I should be loath to fall

Beside the common way,

Weltering in mire, and spurned by all,

Till trodden down to clay.

Nor would I choose to die

All on a bed of grass;

Where thousands of my kindred ie,

And idly rot in mass.

Nor would I like to spread

My thin and withered face

In hortus siccus, pale and dead,

A mummy of my race.

No! on the wings of air

Might I be left to $\mathrm{fly}$,

I know not and I heed not where

A waif of earth and sky!

Or flung upon the stream,

Curled like a fairy-boat;

As through the changes of a dream,

To the world's end to float. 
Who that hath ever been, Could sar to be no more?

Yet who would tread again the scene

He trod through life before?

On, with intense desire,

Man's spirit will move on:

It seems to die, yet, like heaven's fire,

It is not quenched, but gone.

The sun now sheds on the foliage a pale yellow hue, and the poplar is tinged with discolored gold, while the acacia folds up its bright foliage, which the sun's rays will expand no more. 'The birch-tree waves its long branches, already stripped of ornament; and the fir, which preserves its green pyramids, balances them proudly in the air. The oak is immovable - it resists the efforts of the wind to strip its stately head; and the king of the forest refuses to shed its leaves until the ensuing spring. We are told that all these trees are moved by different passions; one bows profoundly as if it wished to render homage to him whom the tempest cannot move; another seems desirous of embracing its companion, the support of its weakness; and whlle they mingle their branches together, a third seems universally agitated as though it were surrounded by enemies. Often do we see fallen on the earth, having already lost their bright green verdure, clouds of dead leaves that cover the ground with a restless garment. We love to contemplate the storm that chases, agitates, disperses, and torments, these sad remains of a spring which can never return.

We keep a rainbow all the tıme,

Within our lattice low;

Our vase is crowned with autumn-leaves,

Through whish the sun doth glow,

Lighting up each transparent, gorgeous shadeGreen, crimson, purple, gold - all blending in one oraid.

F. S. 0 . 


\section{SE CRET L O E.}

MOTHERWORT.

'THE clandestina grows at the foot of large trees, in moist and umbrageous places. Its pretty purple flowers are nearly always Lidden under moss or dry leaves.

Yes! tell him - tell him I am well,

Say that this cheek doth deeper glow,

Than was its wont-but do not tell, ' $T$ is the heart's fever makes it so!

And tell him how my lip has curled,

And named his name with idle smile;

But do not tell him for the world,

That tears were in mine eyes the while!

F. s. 0.

\section{SOUL OF MY SOUL.}

\section{VIRGINIAN JESSAMIINE.}

How Inany ravishing harmonies spring up on every side, from the association of plants with the animal creation! Behold the Virginian jessamine, with its beautiful verdure and purple flowers! The humming-bird makes its nest in one of the leaves, which it rolls into the shape of a horn; it finds its sustenance in the nectareous vessels of its red flowers, which are similar to those of the foxglove: and its little body, when resting on 
the jasmine-flower, appears like an emerald set in coral. It is sometimes so tame or fearless that it may be taken with the hand. This little being is the soul and the life-of the plant that cherishes it.

Oh! the pet and the darling of nature - whose plume,

Through the woods, like a sunbeam, doth playfully dartThe humming-bird! bathing in dew and perfume,

That hide in the crimson jasmine's heart, While he blends, with thr blossom, his own rich bloom, Till you hardly can tell them apart.

F. S. 0 .

\section{SILE N C E. \\ WHITE ROSE.}

THE god of silence was represented under the form of a young man, with one finger placed on his lips, and holding a white rose in the other hand. We are told that Love gave him this rose to secure his favour. The ancients sculptured a rose over the doors of their festive halls, to interdict the guests from repeating anything that was spoken. Byron has rendered it sacred to the silence of the tomb. In the "Bride of Abydos," he says, that, o'er the tomb of Zuleika -

A single rose is shedding

Its lovely lustre, meek and pale;

It looks as planted by despair -

So white, so faint, the slightest gale

Might whirl the leaves on high. 


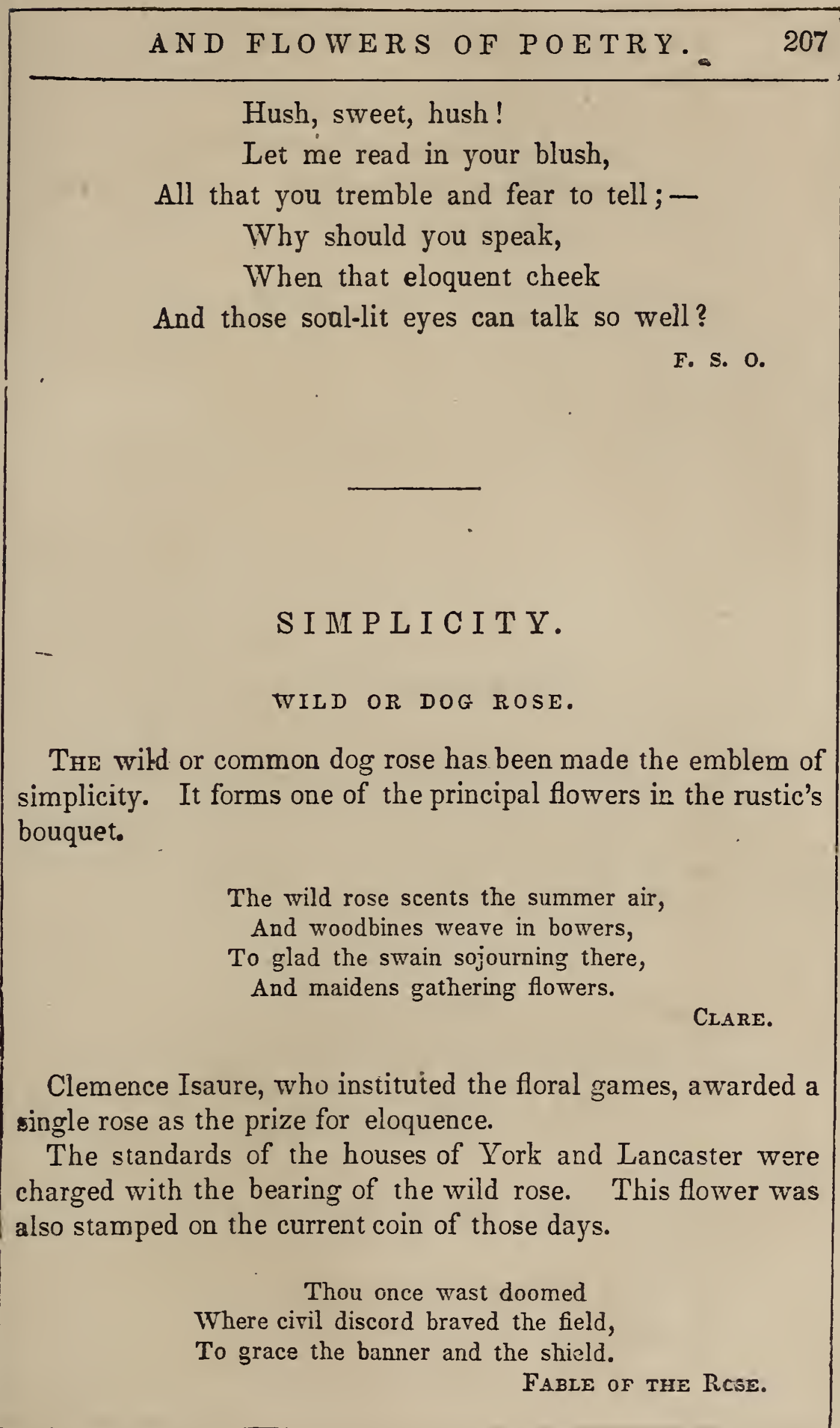


208 THE POETRY OF FLOWERS

She clasps no golden zone of pride, Her fair and simple robe aroundBy flowing riband, lightly tied, Its graceful folds are bound:

And thus attired -- a sportive thing, Pure, loving, guileless, bright, and wild, Proud Fashion! match me in your ring, New England's mountain-child!

F. S. 0 .

\section{S I N C E R I T Y.}

\section{FERN.}

"FEnN often affords an agreeable seat to lovers; its ashes are used in the manufacture of glasses for the convivial party; and all the world knows that love and wine make men sincere."

I dearly love a changing cheek, That glows or pales, as Feeling chooses, And lets the free heart frankly speakUpon it what the tongue refuses;

Where eloquent blushes burn and fade, Rich with the wealth of warm emotion, Or starry dimples mock the shade, Like jewels in a restless ocean. 


\section{SHAR P NES S.}

\section{B A R E R R Y.}

THE fruit of the barberry is so very acid that birds will seldom eat them. The tree is armed with thorns, and the flowers are so irritable, that at the slightest touch all the stamina close around the pistil. Thus this tree bears all the characteristics of persons whose temper is sharp and irritable.

Now Fate preserve thee-lady fair !-

I will not breathe the Frenchman's prayer,

Who to the maiden's great alarm,

Exclaimed: "God pickle you, madame!"

- But "Fate preserve thee!"- even as they,

Our housewives notable, allay,

With sugared sweets, an acid juice,

And store it up for future use; -

So "Fate preserve thee," or thou 'It stay,

Unplucked, upon the parent-tree;

Like barberries only fit to be

Facked in a gallipot away;

Unless thy sharpness be effaced,

Thou'rt far too sour to suit my taste. 


\section{S K I L L.}

\section{SPIDER-ORPHR YS.}

Accordivg to ancient fable Arachne was very skilful in spinning and weaving, and dared to defy Minerva in the exercise of those arts. The offended goddess changed the imprudent Arachne into a spider, which, according to Guillim, is free of the IV eavers' Company. The spider-orphrys closely resembles the insect which, under a hideous form, still retains its skill and address.

He plucks the pearls that stud the dsep, Admiring beauty's lap to fill;

He breaks the stubborn marble's sleep, And mocks his own Creator's skill.

SPrague.

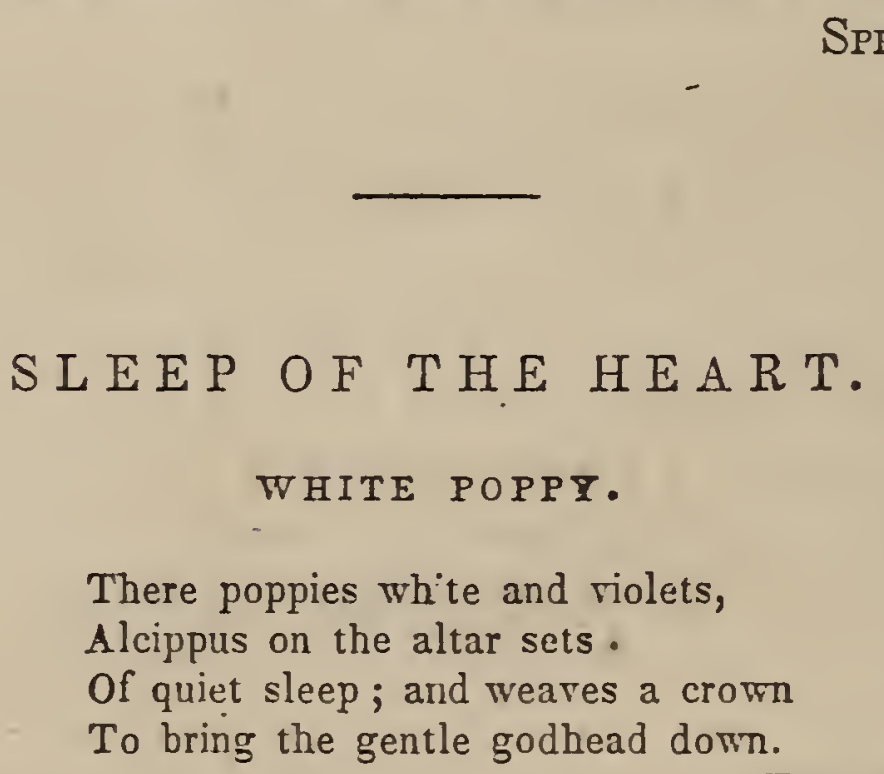

Fracastorio.

Av insipid oil is expressed from the grains of the white poppy, which ca.ms the senses and provoles sleep.

The palace of Somnus, who presided over sleep, was represented as a dark cave, into which the sun's rays never penetra- 
ted; at the entrance grew poppies and other somniferous herbs; the Dreams watched over his couch, attended by Morpheus, his prime minister, holding a vase in one hand, and grasping poppies in the other.

You can charm to sleep the physical powers,

With the oil distilled from a poppy's leaves;-

Say, can your science find us flowers,

Whose magic may hush a heart that grieves?

F. S. 0 .

\section{SIMIL ON ME STILI.}

\section{SUNFLOWER。}

TFE helianthus constantly turns toward the sun. In Peru the virgins of the sun wore an imitation of this flower, wrought in gold.

Eagle of flowers! I see thee stand, And on the sun's noon-glory gaze, With eye like his! - thy lips expand, And fringe their disk with golden rays.

\section{J. Montgoner $\mathrm{Y}$.}

Oh! the heart that has truly loved, never forgets, But as truly loves on to the close, As the sunflower turns on her god, when he sets, The same look that she turned when he rose. Moore. 


\section{S MI L E S.}

CROCUS.

Tris pretty flower blooms in early spring. Its colors are yellow, purple, and white.

Down in my solitude under the snow,

Where nothing cheering can reach me;

Here, without light to see how to grow,

I'll trust to nature to teach me.

I will not despair - nor be idle, nor frown,

Locked in so gloomy a dwelling;

My leaves shall run up, and my roots shall run down, While the bud in my bosom is swelling.

Soon as the frost will get out of my bed, From this cold dungeon to free me,

I will peer up with my little bright head, And all will be joyful to see me.

Then from my heart will young petals diverge, As rays of the sun from their focus;

I from the darkness of earth will emerge, A happy and beautiful Crocus!

Many, perhaps, from so simple a flower, This little lesson may borrow,

Patient to-day, through its gloomiest hour, We come out the brighter to-morrow. 

AND FLOWERS OF POETRY.

ILLUSTRATION OF PLATE.

$$
\text { Pansies. - Broom. }
$$

My heart would be at ease, if my solitude were blest with your society.

If thou wert here, my fairy-queen !

With all thy graces, wiles, and spells, How soon would show this sylvan scene, What magic in thy presence dwells!

The crests of foam the wavelets wear, Would change to crowns of living pearl; And balm would be the ambient air, And radiant joy the sun, my girl! 


\section{SOL I T U E.}

HEATH.

The foliage of this plant is evergreen, of varied and beautiful shapes, and on examination is found as pleasing as its sin. gular blossom. In our floral hieroglyphics it is made emblematical of solitude; and thus, when the rustic lover offers his mistress a bouquet of heath and pansies, she understands that if his solitude were charmed by her society his heart would be at ease.

There are now about four hundred different species of heath, of such variety of colours and forms that no pen can describe them. On sume we observe little waxlike flowers, and others present us with pendent pearls; some are adorned with coraline beads, while others seem to resemble the golden trumpet, or tempting berries, or porcelain of bell or bottle shape. Globes of alabaster hang on the slender spray of some, and others, again, remind us of Lilliputian trees, bedecked with Turkish turbans in miniature. "Their colours are not less varied than their shape, while the foliage is equally beautiful in its apparent imitation of all the mountainous trees, from the Scottish fir to Lebanon's boasted cedar."

A heath's green wild lay present to his view, With shrubs and field-flowers decked of varied hue.

Oh! to lie down in wilds apart,

Where man is seidom seen or heard, In still and ancient forests, where Mows not his scythe, ploughs not his share, With the shy deer and cooing bird! 
To go in dreariness of mood,

O'er a lone heath, that spreads around,

A solitude like a silent sea,

Where rises not a hut or tree,

The wide-embracing sky its bound!

Oh ! beautiful those wastes of heath,

Stretching for miles to lure the bee,

Where the wild bird, on pinions strong,

Wheels round and pours his piping song,

And timid creatures wander free.

Mary HowitT.

SORROWFUL REMEMBRA N E S.

PHEASANT'S-EYE, OR FLOS ADONIS.

Look, in the garden blooms the flos adonis, And memory keeps of him who rashly died, Thereafter changed by Venus, weeping, to this flower.

ANON.

Adonis was killed by a boar when hunting. Venus, who had quitted the pleasures of Cythereus for his sake, shed many tears at his melancholy fate. The fable tells us that these were not lost, but mingling witn the blood of Adonis, the earth received them, and forthwith sprang up a light plant covered with purple flowers. . Brilliant and transient flowers; alas! too faithful emblems of the pleasures of life! you were consecra- 
ted by the same beauty as the symbol of sorrowful remembrances.

By this the boy, that by her side lay killed, Was melted like a vapour from her sight; And in his blood, that on the ground lay spilled, A purple flower sprang up, chequered with white.

SIIAKSPEARE.

One tatal remembrance, one sorrow that throws Its bleak shade alike, o'er our joys and our woes; To which life, nothing darker or brighter, can bring, For which joy has no balm and affliction no sting! Moore.

\section{S P L E N O UR.}

\section{OBELIA.}

Twrs brilliant flower is frequent in the southern and western parts of the United States.

She stood 'mid the dazzling insignia of Wealth;

But the jewels, that shone o'er her beauty and bloom, Were less fair than the sunny ray smiling by stealth,

Through the rose-teinted damask, that curtaineil ine room.

$$
\text { F. S. } 0 \text {. }
$$




\section{S T R E N G T H.}

\section{EENNEL.}

A savoury odour blown, more pleased my sense Than smell of sweetest fennel, or the teats of ewe, or goat, dropping with milk at even.

Miltor.

THE gladiators mingled this plant with their food, from a supposition that it tended to increase their strength. After the games were over, the conqueror was crowned with a wreath of fennel. The Romans named the plant anethum.

The wealth of rich feelings - the deep - the pure With strength to meet sorrow and faith to endure.

F. S. 0

\section{S T O I C I S M.}

B OX.

THE tree box loves the shade, and will grow under the drip of trees. It maintains its verdant appearance in winter as well as summer. It requires no care, and endures for centuries. On account of its resistance to the changes of the seasons, and the power of time, it has been made the emblem of stoicism. 
There is strength

Deep bedded in our hearts, of which we reck But little till the shafts of heaven have pierced Its fragile $d w e l l i n g$. Must not earth be rent Before her gems are found?

Mrs. Henains.

Strange heart of man! that even 'mid wo swells high, When through the foam he sees his proud bark sweep, Flinging out joyous gleams to wave and sky!

Mrs. Henans.

\section{SUSPICION.}

\section{MIUSHROOM.}

Mary species of mushroom are known to be deadly poison. The Ostiacs, a Siberian tribe, make a preparation from the Agaricus muscarius, which will kill the most robust man in twelve hours. Several mushrooms in our country are almost as dangerous; as there is a liquid hid within them of a nature so acrid, that a single drop put on the tongue will produce a blister. The Russians, during their long fasts, live entirely on mushrooms; and are often thrown into violen; convulsions in consequence. We regard them as a dainty dish, but we ought to use them with great caution. Before using them they should be exposed to the heat of boiling water; this will ascertain their quality, as if they are not of a good kind their perfume will be evaporated. 
AND FLOWERS OF POETRY.

Better confide and be deceived,

A thousand times, by treacherous foes,

Than once accuse the innocent,

Or let suspicion mar repose.

F. S. 0 .

S WEET REM EMBRANCES.

PERIWINKLE.

Through primrose tufts in that sweet bower,

The periwinkle trailed its wreaths;

And ' $t$ is my faith that every flower

Enjoys the air that kreathes.

WORDSWORTH.

THERE is an agreeable softness in the delicate blue colour of the periwinkle, and a quietness in the general aspect of the flower, that appears to harmonize with the retired situations where it loves to grow. It prefers the shady banks of the grove, rather than to meet the meridian sun in the society of the gay plants of the parterre.

In France this flower has been made emblematical of the pleasures of memory from the circumstance of Rousseau's saying, in one of his works, that, as he and Madame Warens were proceeding to Charmettes, she was struck by the appearance of some blue flowers in the hedge, and exclaimed, "Here is the periwinkle still in flower." He then tells us, that thirty years afterward, being at Gressier, with M. Peyron, climbing a hill, he observed some in blossom among the bushes, which bore his memory back at once to the time when he was walking with Madame Warens, and he inadvertently cried, "Ah! there is the periwinkle." Rousseau relates this anecdote as a proof of 
the vivid recollection he had of every incident which occurred at a particular time of his life, and hence this flower is made to represent "les doux souvenirs."

Oh! Memory, thou fond decelver,

Still importunate and rain,

To former joys recurring ever,

And turning all the past to pain.

Thou, like the world, the oppressed oppressing

Thy smiles increase the wretch's wo;

And he who wants each other blessing,

In thee must erer find a foe.

GoLDSMrITH.

This plant attaches itself strongly to the earth, which it adorns; it encloses itself entirely with its flexible branches, which are covered with flowers that seem to reflect the colour of the sky. Thus our first sentiments are so lively, so pure, so innocent, that they seem to have a celestial origin; they mark a period of momentary happiness, and they ought to be treasured up among our most endearing recollections.

And thus as in Memory's bark we shall glide

To visit the scenes of our boyhood anew-

Though oft we may see, looking down on the tide,

The wreck of full many a hope shining through -

Yet still, as in fancy we point to the flowers,

That once made a garden of all the gay shore,

Deceived for a moment, we'll think them still ours,

And breathe the fresh air of life's morning once more.

MOORE. 


\section{S Y M P A T H Y.}

\section{THRIFT.}

The marygold above, to adorn the arched bar ; The double daysie, thrift, the button batcheler.

DRAYTON.

The scientific name of this plant, statıce, is derived from the Greek word orarıкos (statikos), which expresses that which has the power to stop, unite, or retain. Next to box, it forms the prettiest border plant we know. The flowers of the thrift are small, numerous, turning toward the sun, and form pretty blue cups. To be seen to advantage they should be viewed through a microscope. The plant is cultivated for its modest beauty, but it grows naturally in marshy places, and especially by the seashore, where it binds the sands togetner by its numerous roots. This quality is the bond which unites man to his fellowman, and, without it, each individual would be a distinct species by himself.

Kindness by secret sympathy is tied;

For noble souls in nature are allied.

DRYDEN.

Shame on those breasts of stone that cannot melt, In soft adoption of another's sorrow!

Aaron Hill. 


\section{THE HEART THAT KNOWS NOT L O V E.}

$$
\text { WHITE ROSEBUD. }
$$

Untouched, upon its thorny stem, Hangs the pale rose unfolding.

HURDIs.

BEFORE the breath of Love animated the world, all the roses were white, and every heart was insensible.

'T was from Love, I borrowed, too, My sweet perfume, my purple hue.

ANon.

When Love was born in Eden's bower, The first soft blush of Eve was shed On a white rose - her emblem-flower Which ever since has blossomed red!

F. S. 0 .

\section{T I II E.}

\section{WHITE POPLAR.}

THE white poplar is one of the most valuable of our indigenous trees, and grows to the beight of more than ninety feet, towering its superb head upon a straight silvered trunk. The ancients consecrated it to Time, because the leaves are in con- 
tinual agitation; and being of a blackish green on the upper side, with a thick white cotton on the other, they were supposed to indicate the alternation of the day and night.

And Time, with a footstep soft and light, As the maiden's own, went by that night. F. S. 0 .

\section{T I M I D I T Y.}

MARVEL OF PERU.

THrs plant is called mirabilis, and with some degree of rea son, for it is a most admirable flower; it expands its richly-dyed corollas at night, whence it has been named by the French, belle-de-nuit.

It is universally considered to be the emblem of timidity, from its shunning the brilliant light of day, and only venturing to display its charms in the cool of the evening.

The mimosa, or sensitive plant, has been assigned as the symbol of chastity and prudery, but we think it may be more properly used as the sign of timidity; as it seems to fly from the hand that would touch it. At the least approach, the leaves shrink within themselves. The petiole then droops, and if the plant be low, it touches the earth. Even a sloud passing between it and the rays of the sun, is sufficient to change the situation of its leaves and the general aspect of the plant.

Timidity, of all afraid, Her wreath of the mimosa braid. 
The blossom that bashfully shuns the daylight, And yields all its sweetness and bloom unto night.

F. S. 0 .

\section{THA N K F L N E S S.}

\section{A GRIMION Y}

AGRIMONY is a pretty species of campanula, whose flowers of the most delicate lilac colour are suspended from the plant like little bells. The French commonly call it "Religieuse des Champs ;" and Madame de Chastenay says, in her Calendar of Flora: "It is suspected that this has been called agrimony from the resemblance of its flowers to the hermit's bell. For my own part I think that gratitude has given it the name of 'Religieuse des Champs,' in honour, probably, of some kind, tender, and beneficent Sister of Charity."

And the nuns used to dream, as they roamed about The convent-garden of St. Ursula, That, at matins and vespers, a peal rang out, From the fairy bells of the campanula. 
THINK O F I E.

PANST, OR HEART'S-EASE.

pray you, love, remember,

There's pansies - that's for thoughts.

SHAKSPEARE.

THE teints of this flower are scarce less varied than the names that have been bestowed upon it. That of pansy is a corruption of the French name, pensee, thought.

Leigh Hunt introduces the heart's-ease into his verses:-

The garden's gem,

Heart's-ease, like a gallant bold,

In his cloth of purple and gold.

Phillips observes that the most brilliant purples of the artist appear dull when compared to that of the pansy; our richest satins and velvets coarse and unsightly by a comparison of texture; and, as to delicacy of shading, it is scarcely surpassed by the bow of Iris itself.

Oh ! long may the blossom, whatever betide, The tenderest breath of the summer-wind win, And smile in its beauty, thy threshold beside, Bright symbol, sweet lady of heart's-ease within !

F. S. 0 . 


\section{TRA N Q U I L I T Y.}

ROCK II $\triangle$ DWORT.

There is a gentle element, and man

May brcathe it with a calm unruffled soul, And drink its living waters, till his heart

Is pure, and this is human happiness.

WIL1.IS.

This plant was esteemed by the ancients on account of its supposed power to allay anger. The species generally are showy plants, and of easy culture. The rock madwort is very ornamental early in the season.

\section{My heart is like a sleeping lake, \\ Which takes the hue of cloud and sky, And only feels its surface break, \\ When birds of passage wander by, Who dip their wings and upward soar, And leave it quiet as before.}

WILLIS.

\section{TREACHER Y.}

\section{BILBERRY.}

THis species of whortleberry is an elegant and also a fruitbearing plant. "The young fresh green leaves, and waxlike "ed flowers, appear in May, and toward autumn the leaves grow darker and firm, and the ripe berries are gathered in the north 
for tarts;" and in the highlands they are eaten with milk; and also in Derbyshire, where they are found in great quantities.

The bilberry has been made the symbol of treachery from rhe following fable: "CEnomaus, father of the beautiful Hippodamia, had for his charioteer the young Myrtilus, son of Mercury. Enomaus offered the hand of his daughter to any one who should outdo him in a chariot-race. Pelops, anxious to obtain Hippodamia, bribed Myrtilus to overthrow his master's chariot, and Enomaus was killed. In dying, he cried for vengeance, when Myrtilus was changed into the shrub which has ever since borne his name."

Thou hast come - not to cherish -

To win but my heart;-

It is thine till it perish;-

Now, trifler, depart'

F. S. 0 .

\section{T R U TH.}

\section{BITTER-SWEET NIGHTSHADE.}

THE ancients thought that truth was the mother of the virtues, the daughter of time, and the queen of the world. We moderns say that that divinity hides herself at the bottom of a well, and that she always mingles some bitterness with her sweets; and we appoint for her emblem a useless plant that loves the shade and is ever clothed in green. The bitter-sweet nightshade is, we believe, the only plant in our climate, that sheds and reproduces its foliage twice in one year. Its roots smell somewhat like the potato, and being chewed, produce a sensation of bitterness on the palate, which is succeeded by 
sweetness. From this singular fact it derives 1ts specific name, "bitter sweet."

Spring has passed and has left behind Perfumed gardens to scent the wind, And beautiful flowers that uless the eyes, With visions of a lost paradise:

But thou art lovelier far than these, And owest no charm to sun or breeze: Their lifeless colours could never vie With the spirit that speaks in thy laughing eye. JoHN KeEse.

I love a hand that meets mine own With grasr tnat causes some sensation;

I Jove a voice whose varying tone From Truth has learned its modulation.

F. S. 0 .

\section{U T I L T Y.}

\section{GRASS}

He causeth the grass to grow for the cattle, and herb for the service of man, that he may bring forth food out of the earth.

PsalM civ. 14.

Ir will be admitted that what is the most useful, is in nature the most conmmon; and of all vegetable productions, what is 
there more common than grass? It clothes the earth with a verdant carpet, and it yields food - nay, it "grows for the cattle," in obedience to the Creator's word:-

Let the earth

Put forth the verdant grass, herb yielding seed, And fruit-tree yielding fruit after her kind, Whose seed is in herself upon the earth. He scarce had said, when the bare earth, till then Desert and bare, unsightly, unadorned, Brought forth the tender grass, whose verdure clad Her universal face with pleasant green; Then herbs of every leaf, that sudden flowered, Opening their various colours, and made gay Her bosom, smelling sweet.

Milton.

Howit observes: "When grasses of the larger species are collected and disposed tastefully, as I have seen them by ladies, in vases, polished horns, and over pier-glasses, they retain their freshness through the year, and form, with their elegantly pensile panicles, bearded spikes, and silken plumes, exceedingly graceful ornaments."

Lovely as useful - still this graceful grass

Reminds me of the modest peasant-lass,

Who blooms in lowly life - the kind and fair,

Warmed by glad Nature's sun and freshened by her air!

F. s. 0 . 


\section{A R I E T Y. \\ CHINA-ASTER.}

THE China-aster is made the emblem of variety; and owes its principal charms to a careful culture of the skilful gardener, who has surrounded its golden disks with every colour of the rainbow. So study produces, an endless variety in the refinement of the human mind. Though majestic and brilliant, the China-aster is not the imprudent rival of the rose, but succeeds it, and consoles us for its absence.

The greatest wonder, Mary,

Is this, that while, to me,

Your charms each moment vary,

Your heart should constant be.

F. S. 0 .

\section{VIRGIN PRIDE. \\ GENTIANA FRITILLARIA.}

This exquisitely-delicate flower, folding its soft blue petals so modestly together, seems a fitting emblem of a young and lovely girl, bashful or too proud for display.

Her arms were folded on her breast,

In purity and pride,

With modest sweetness, when addressed,

Her low soft voice replied. 


\title{
WEAK BUT VINTING。
}

\author{
MOSCHATẼ.
}

THis plant, commonly called musk-crowfoot, emits an odour so light and agreeable, that it pleases even those who have a particular dislike to musk. It is minute, and by no means beautiful, and grows in obscure places. Its generic name is adoxa, which is derived from the Greek, and signifies inglorious.

$\mathrm{Oh}$ ! too convincing - dangerously dear -

In woman's eye, the unanswerable tear;

That weapon of her weakness she can wield,

To save, subdue - at once her spear and shield;

Avoid it -- virtue ebbs and wisdom errs,

Too fondly gazing on that grief of hers!

What lost a world, and bade a hero fly?

The timid tear in Cleopatra's eye.

Yet be the soft triumvir's fault forgiven,

By this - how many lose - not earth - but heaven !

BYRON.

\section{W ILL Y U PLEDGE IM E?}

\section{SI DESA DDLE-FLOW ER.}

THE whole of this genus are plants of a very singular structure. The Saracenia purpurea is the only one which endures our climate. The leaves are formed by a large hollow tube, 
swelling in the midide, curved and diminishing downward, till it ends in a stem, contracted at the mouth, furnished with a large, spreading, heart-shaped appendage at top, which is hairy within, the hairs pointing downward; and a broad, wavy wing extending the whole length on the inside. The full-grown leaves will contain a wireglass of water, and are rarely found empty.

Oome, pledge me, sweet, in Aidam's cup,

' $T$ is pure and fresh like thee:

The wine that pleasure's votaries sup

Will stain the spirit free;

But here can be nor shade nor sin

For you can see your face within!

F. S. 0 .

\section{WIN ME AND WEAR ME.}

\section{LADY'S SLIPPER.}

THrs plant is common in our northern woods. Its flowers, are yellow, purple, and white.

I am not to be drawn off and on like the trifle, Whose name is bestowed on the blossom I send; My affections no dreaming romancer shall rifle, If ou: rows be not heart-hallowed - here let them end. 


\section{W I S D O MI.}

WHITE MULBERR

THE ancients named the white mulberry tire tree of wisdom, because of its tardiness in putting forth its leaves. We say, "foolish almond, wise mulberry," berause the almond is the first to flower. A branch of almond, joined with a branch of white mulberry, expresses that wisdom should temper activity.

"This species of mulberry is commonly cultivated in France and other countries for its leaves, to feed silkworms; and in many parts of the continent, when the leaves are wanted for the worms, they are stripped off the young shoots, which are left naked on the tree: in other places the shoots are cut off, which is not so injurious to the tree, while the points of the shoots as well as the leaves are eaten by the worms."

Oh, sacred solitude! divine retreat!

Choice of the prudent! envy of the great!

By thy pure stream, or in the waving shade,

We court fair wisdom, that celestial maid!

Young.

\section{Y U THFUL CHAR IM S}

\section{ROSEBUD.}

Wro can say whether the white rose, or the red, the budding, or the full blown, has been most celebrated? Oft, indeed, have all been sung; and the rosebud, from its grace, and graduallymaturing beauty, has not been inappropriately rade emblematical of youthful charms. 
Alas! "all that's bright must fade!" How true a picture of human life, and of the growth and decay of human beauty, is exhibited in the following lines by Jeremy Taylor: "But so I have seen a rose revrly springing from the clefts of its hood: and at first it was fair as the morning, and full with the dew of hearen, as a iamb's fleece; but when a rude breath had forced open its modesty, and dismantled its youthful retirement, it began to put on darkness, and decline to softness, and the symptoms of a sicizly age came on; it bowed its head and broke its stalix : and at night having lost some of it leaves, and all its beauty; is fell with the portion of weeds and outworn faces."

I pray thee do not blossom yet, My fairy rose - my pretty pet!

Let not the wooing light and air Beguile those tender leaves apart, But keep thy wealth of incense there, With Patience at thy blooming heart

F. S. 0 .

THE DYING ROSEBUD'S LAIIENT.

Af me! ah! wo is me!

That I should perish now, With the dear sunlight just let in, Upon my balmy brow!

My leaves, instinct with glowing life, Were quivering to unclose,

My happy heart with love was rife; i tuas almost a rose!

F. S. 0 . 
YOUR BLUSH HAS WON ME.

$\triangle \mathrm{ZALE} \Lambda$.

THIs is an exceedingly beautiful shrub with rose-coloured flowers found in the woods of North America.

I know a cheek whose blushes, As they trembling come and go,

I could gaze upon for ever, If it did not pain thee so.

F. s. o.

Playful blushes, that seem naught But luminous escapes of thought.

MoORE.

YOUR IMAGE IS ENGRAVEN ON MY $H E A R T$.

SPINDLE-TREE.

THIs shrub bears the name of spindle because that article is most commonly made of its wood ; it is also used in the preparation of crayons. The sculptor and the turner value it highly. If the wood be useful to the arts, the shrub has claims to the esteem of the cultivator. The hedges which they ornament with rosy fruit have a very pretty effect in the autumn. 
THE POETRY OF FLOWERS

Love drew your picture in my "heart of heart," And memory preserves it beautiful

F. S. 0 .

\section{Y OU TH.}

WHITE LIIAC.

That lilac's cleaving cones have burst,

The milkwhite flowers revealing;

E'en now upon my senses first,

Methinlss their sweets are stealing.

BLACKWOOD'S MAGAZINE.

ON account of the purity and short duration of the delicate flowers of the white lilac, it has been made the symbol of youth; of that fleet and enchanting period which no wealth can purchase, nor power retain or restore.

The hues of youth,

Carnationed like a sleeping infant's cheek, Rocked by the beating of her mother's heart, Or the rose-teints, which summer's twilight leaves Upon the lofty glacier's virs.in snow,

'The blush of earth embracing with her heaven Tinge thy celestial aspect and make tame The beauties of the surbow that bends o'er thee. 
AND FLOWERS OF POETRY.

\section{'ILLUSTRATION OF PLATE.}

\section{Mignionette.-Heliotrope.-Pink.}

Your $q: a$ ities surpass your charms; I love you with a pure and do. voted love.

I kNow not if that face be fair, If what the world would beauty call, May beam and blush and brighten there, In lip and eye and ringlet's fall:

So richly eloquent through those eyes, Your soul, of love and truth doth speak, So soft the timid heart-hues rise, In glowing witchery, on your cheek,

That, whether it be fair or dark, Or they, the eyes, be black or blue,

I never yet have cared to mark, Or marking, have forgot the hue:

I only know - howe'er you smile, Whate'er your tresses' teint or fashion, The graces of your mind beguile My heart to own a deathless passion.

F. S. 0 . 
YOUR QUALITIES SURPASS YOUR C H A R M S.

MIIGNIONETTE.

No gorgeous flowers the meek reseda grace, Yet sip with eager trunk yon busy race Her simple cup, nor heed the dazzling gem That beams in Fritillaria's diadem.

Dr. Evars.

THE odour exhaled by this little flower is thought by some to be too powerful for the house. Linnæus compares its perfumes to those of ambrosia; and it is sweeter and more penetrating at the rising and setting of the sun than at noon.

The mignionette has found its way into the armorial bearings of an ancient Saxon family; and the following romantic story is said to have introduced this fragrant little flower to the pursuivant-at-arms:-

The Count of Walstheim was the favoured aspirant for the hand of Amelia de Nordhourg, a young lady possessing all the charms requisite for the heroine of a modern novel, excepting that she delighted in exciting jealousy in the breast of her intended lord. As she was the only child of a widowed mother, a female cousin, possessing but little personal beauty, and still less fortune, had been brought up with her from infancy as a companion, and as a stimulus to her education. The humble and amiable Charlotte was too insignificant to attract much attention in the circles in which her gay cousin shone with so inuch splendour, which gave her frequent opportunities of imparting a portion of that instruction she had received to the inore humble class of her own sex. Returning from one of these charitable visits, and entering the gay saloon of her aunt, where her exit or entrance was scarcely noticed, she found the party amusing themselves in selecting flowers, while the count 
and the other beaux were to make verses on the choice of each of the ladies. Charlotte was requested to make her selection of a flower; the sprightly Amelia had taken a rose, others a carnation, a lily, or the flowers most likely to call forth a compliment; and the delicate idea of Charlotte, in selecting the most humble flower, by placing a sprig of mignionette in her bosom, would probably have passed unnoticed, had not the flirtation of her cousin with a dashing colonel, who was more celebrated for his conquests in the drawing-room than the battle-field, attracted the notice of the count so as to make his uneasiness visible, which the amiable Charlotte, ever studious of Amelia's real happiness, wished to amuse, and to call back the mind of her cousin, demanded the verse for the rose. The count saw this affectionate trait in Charlotte's conduct, took out his pencil, and wrote for the rose,

Elle ne vit qu'un jour, et ne plait qu'un moment,

which he gave to the gay daughter, at the same time presenting the humble cousin with this line on the mignionette:-

Ses qualités surpassent ses charmes.

Amelia's pride was roused, and she retaliated by her attention to the colonel, which she carried so far as to throw herself in to the power of a profligate, who brought her to ruin. The count transferred his affections from beauty to amiability; and, rejoicing in the exchange, to commemorate the event which had brought about his happiness, and delivered him from a coquette, he added a branch of the sweet reseda to the ancient arms of his family, with the motto :-

Your qualities surpass your charms.

Your soul is fairer than your face, Your genius brighter than your smile; 
Yet in your every outward grace,

Is beauty that might well beguile, Without the charm of heart and mind, An angel, in yon heaven enshrined.

F. S. 0 .

\title{
YOUR LOOKS FREEZE ME
}

\author{
FICOIDES, OR ICE-PLANT.
}

With pellucid studs the ice-flower gems His rising foliage, and his candied stems.

DARWIN.

TuE leaves of this singular plant are covered with transparent vesicles full of water. When in the shade it seems to be gemmed with dewdrops; but when exposed to the burning sun, it appears scattered over with frozen crystals, which reflect with great brilliancy the rays of the sun ${ }^{-}$on this account it is commonly called ice-plant.

The cold in clime are cold in blood, Their love can scarce deserve the name, - But mine was like the lava-flood, That boils in Etna's breast of flame.

Brron. 


\section{YOU ARE PERFECT.}

\section{PINE-A P PLE.}

TrEe fruit of the pine-apple, surrounded by its beautiful leaves, and surmounted by a crown in which the germe of a plant is concealed, seems as though it were sculptured in massy gold. It is so beautiful that it appears to be made to please the eyes; so delicious that it unites the various flavours of our best fruits; and so odoriferous that we should cultivate it if it were only for its perfume.

Keep, keep the maiden's dowry,

Her hand, her heart I claim, That little hand is more to me, Than power, rank, or fame, That heart's pure love is wealth, my lord, No more your coffers name!

\section{F. 8. a.}

\section{YOUARE DAZZLING BUT DAN. GER O US.}

\section{SNAPDRAGON.}

THE flowers of the snapdragon are sometimos of so vivid scarlet, that we cannot look upon them with a fixed eye. 
Lips in whose rosy labyrinth, when she smiled, The soul was lost; and blushes, swift and wild, As are the momentary meteors sent Across the uncalm, but beauteous firmament; And then her look - oh! where's the heart so wise, Could unbewildered meet those matchless eyes?

MOORE.

\section{YOU ARE MY DIVINITY.}

AIERICAN COWSLIP.

Smile like a knot of cowslips on the cliff.

BLAIR.

THE elegant stem of a single root of this plant springs from the centre of a rosette of large leaves crouched on the earth. In April it is crowned with twelve pretty flowers with the cups reversed. Linnæus has given it the name of "Dodecathenn," which signifies "twelve divinities," a name, perhaps, somewhat too extravagant for a small plant so modest in its appearance. An American writer says of them, in their indigenous soil, that they resemble a cluster of bright yellow polyanthuses. "Our gold cowslips," he adds, "look like a full branch of large clustering king-cups: they carelessly raise themselves on their firm stalks, their corollas gazing upward to the changing spring sky, as they grow amid their pretty leaves of vivid green. They adorn almost every meadow, and shed a glow of beauty wherever they spring." 
One, who could change the worship of all climates, And make a new religion wherever she comes, Unite the differing faiths of al. the world, To idolize her face.

DRYDEN.

\section{YOUR FROWN I DEFY.}

\section{ANEMIONE.}

THE delicate anemone hepatica is one of the earliest visiters in spring, flowering in sunny spots before the snow has left the ground.

\section{Your coldness I heed not, Your frown I defy, Your affection I need not; \\ The time has gone by,}

When a blush or a smile on that cheek could beguile My soul from its safety, with witchery's wile!

\section{Then, lady, look kindly, Or frown on me still, No longer all blindly I yisld to your will!}

Too tightly you drew the light reins of command, And your victim is free - for they broke in your hand. 
Oн! they looked upward in every place

Through this beautiful world of ours,

And dear as a smile on an old friend's face

Is the smile of the bright, bright flowers!

They tell us of wanderings by woods and streams;

They tell us of lanes and trces;

But the children of showers and sunny beams

Have lovelier tales than these-

The bright, bright flowers!

They tell of a season when men were not, When earth was by angels trod,

And leaves and flowers in every spot

Burst forth at the call of God;

When spirits, singing their hymns at even,

Wandered by wood and glade,

And the Lord looked down from the highest hearen,

And blessed what he had made -

The bright, bright flowers!

That blessing remaineth upon them still,

Thongh often the storm-cloud lowers,

And frequent tempests may soil and chill

The gayest of earth's flowers.

When Sin and Death, with their sister Grief,

Made a lome in the hearts of men,

The blessing of God on each tender leaf

Preserved in their beauty then -

The bright, bright flowers !

The lily is lovely as when it slept

On the waters of Eden's lake;

The woodbine breathes sweetly as when it crept

In Eden from brake to brake.

They were left as the proof of the loveliness

of Adam and Eve's first home:

They are here as a type of the joys that bless

The jast in the world to come-

The bright, bright flowers! 


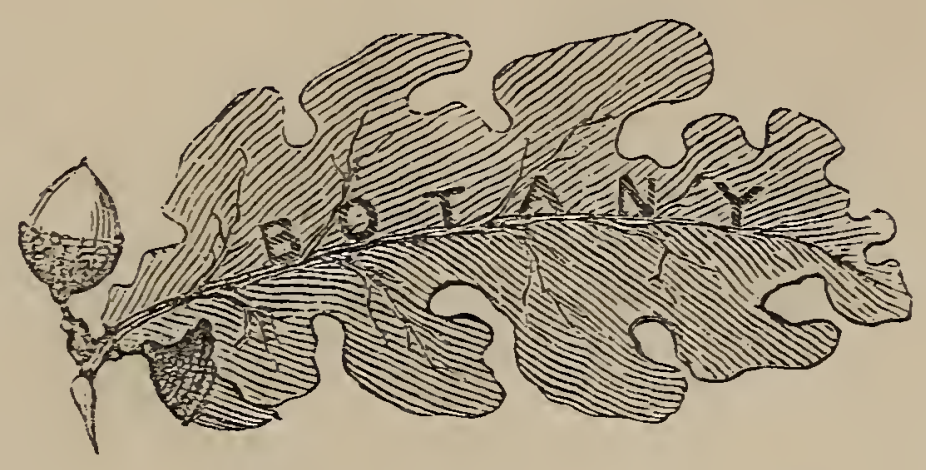

TuE study of botany is one of the most interesting and delightful pursuits, in the whole range of science; presenting to the contemplation of the pupil, a constant succession of sweet and charming forms, and affording him, in all seasons, an elerating and refined amusement. To him - on hill and dale in every grove - by every fount and rill - wherever he goes - he finds a friend - with smiling face and balmy breath that whispers a sweet lesson as he bends above it - a lesson of the wondrous power and love and wisdom of Him who "clothed the lilies of the field."

In spring, the crocus lifts its golden crown to lay it at nis feet, and the blue-eyed violet blesses him with its fragrant sigh :-

Why better than the lady-rose

Love I this little flower?

Because its fragrant leaves are these

I loved in childhood's hour.

Let Nature spread her loveliest,

By spring or summer nursed;

Yet still I love the violet best,

Because I loved it first! 
In summer the rose - " the lady rose" - the rich, the radiant - lavishes upon him its wealth of bloom and its inimitable odour; and in autumn the lovely snowdrop; -

Thou beautiful new-comer,

With white and maiden brow,

Thou fairy gift from summer!

Why art thou blooming now?

No sweet companion pledges

Thy health as dewdrops pass;

No rose is on the hedges,

No violet in the grass;

Thou art watching, and thou only,

Above the earth's snow-tomb;

Thus lovely and thus lonely,

I bless thee for thy bloom.

Even winter has its gifts for him. He will find in the woods, among other treasures, the bramble-rose, the "tears of Job," and the snow-white delicate blossoms of the "fairy's thimble:" -

"What, the thimble of a fairy! and can a fairy sew ?"

Inquired a little, wondering girl - "oh! tell me if you know!

Does she stitch together violet-leaves, to make her fragrant gown,

And wad her cloak, to keep her warm, with flying thistle-down?"

We now present to our readers a short chapter on botany on the Linnæan system.

Every plant is either phenogamus cr cryptogamous. Phenogamous plants have their stamens and pistils sufficiently manifest for examination. Cryptogamous plants either lose their staminate organs before they become manifest, or they are too minute for inspection.

The classes, orders, and genera, of the Linnæan system, are 
founded wholly on the seven elementary organs of fiuctification. These are:-

1. Calyx. - The outer or lower part of the flower, generally green, or not coloured.

2. Corol. - The coloured blossom, within or above the calyx.

3. Stamens. - The mealy or glutinous knobs in the flower, with or without filaments.

4. Pistit. - The central organ of the flower, whose base becomes the pericarp and seed.

5. Pericarp. - The covering of the seed, whether pod, shell, bag, or pulpy substance.

6. Seed. - The essential part, containing the rudiment of a new plant.

7. Receptacle. - The base which sustains the other six parts, being at the end of the flower-stem.

Every calyx is either monophyllous, consisting of one leaf, or prlyphyllous, consisting of more than one leaf. They are farther subdivided into-1. Perianth. - That calyx which adjoins and surrounds the other parts of the flower, as seen in the apple, rose, \&c. About two thirds of all plants have perianths. 2. Involucre. - That calyx which comes out at some distance below the flower, and never encloses it. Involucres are either universal, as in caraway, lovage, \&c.; or partial, as in coriander; or proper, placed beneath a single flower. 3. Spathe.-A kind of membrane, which at first encloses the flower, and after it expands, is left at a distance below it, as daffodil, onion, and Indian turnip. 4. Glume. - That kind of calyx which is composed of one, two, or three valves or scales, cummonly transparent at margin, and often terminated by a long awn or beard. All grasses have glume calyxes. 5. Ament. - An assemblage of flower-bearing scales, arranged on a slender thread or receptacle, each scale generally containing the lateral calyx of a flower, as in the willow, chestnut, pine, \&c. 6. Calyptre.-The cap or hood of pistillate mosses, resembling, in form and position, an extinguisher set on a candle. Conspicuous in the common haircap-moss. 7. Volva. - The ring or wrapper at firs: 
enclosing the pileus or head of a fungus; and which, after the plant has arrived at maturity, contracts and remains on the stem, or at the root.

Every corol is either monopetalous, consisting of one petal or flower-leaf, or polypetalous, consisting of more than one. The monopetalous corols are divided into-1. Bellform. - Holiowed out within the base, as gentian, Canterbury-bells, \&c. 2.Funnelform. - With a tubular base and the border crening gradually like a tunnel, as in the thorn-apple and morning-glory. 3. Salverform. - Having a flat spreading limb or border, proceeding from the top of a tube, as lilac, trailing arbutus, \&c. 4. Wheelform. - Having a spreading border without a tube, or with an exceeding short one, as borage and laurel. 5. Labiate. - it is divided into two general parts, somewhat resembling the lips of a horse or other animal. Labiate corols are either personate (with the throat muffled), as snapdragon; or ringent (with the ihroat open), as mint, motherwort, and catnip. Polypetalous corols are divided into-1. Cruciform.-- Consisting of four equal petals spreading out in the form of a crass, as radish, cabbage, mustard, \&c. 2. Caryaphyllous. - Having five single petals, each terminating in a long claw, enclosed in a tubular calyx, as pink, catchfly, cockle, \&c. 3. Liliaceous. - A corol with six petals, spreading gradually from the base, so as altogether to exhibit a bellform appearance, as tulip, lily, \&c. 4. Rosaceous. - A corol formed of roundish spreading petals without claws, or with very short ones, as rose, apple, strawberry, \&c. 5. Papilionaceous. - A flower which consists of a banner, two wings, and a keel, as pea, clover, \&c. If a corol agrees with none of the above descriptions, it is called anomalous.

The stamen is divided into-1. Anther. - The knob of the stamen, which contains the pollen; very conspicuous in the lily, \&c. Never wanting. 2. Pollen. - The dusty or mealy substance contained in the anthers. Never wanting. 3. Fila. ment. - The part of che stamen which connects the anther with the receptacle, calyx, cr pistil. Of ten wanting.

The pistil is divided into-1. Stigma. - The organ which terminates the pistil; is very conspicuous in the lily, and 
hardly distinguishable in the Indian corn. Never wanting. 2. Germe. - That part of the pistil which, in maturity, becomes the pericarp and the seed; as in the cherry and pompion. Never wanting. 3. Style. - That part of the pistil which connects the stigma and the germe; very conspicuous in the lily. Wanting in the tulip and some other flowers.

The pericarp is subdivided into-1. Silique. - That kind of pod which has a longitudinal partition, with seeds attached alternately to its opposite edges, as radish, cabbage, \&c. 2. Le. gume.-A pod without a partitios, with the seeds attached to one suture only, as the pea. 3. Capsule. - That kind of pericarp which opens by valves or pores and becomes dry when ripe, as in the poppy, which opens by pores, and the mullein by valves. 4. Drupe. - That kind of pericarp which consists of a thick fleshy or cartilaginous coat enclosing a nut or stone, as in the cherry, in which i $i$ is said to be berrylike; and in the walnut, where it is $d r y$. 5. Pome. - A pulpy pericarp, without valves, which contains within it a capsule, as apples, quinces, \&c. 6. Berry. - A pulpy pericarp enclosing seeds without any capsule, as currant, grape, cucumber, and melon. 7. Strobile. - An ament with woody scales, as the fruit of the pine.

The seeds are subdivided into-1. Cotyledon. - The thick fleshy lobes of seeds; very manifest in beans, whose cotyledons grow out of the ground in the form of two large succulent leaves. Many plants, as Indian ccrn, wheat, the grasses, \&c., have but one cotyledon. 2. Corcle. - The rudiments of the future plant, always proceeding from the cotyledon; easily distinguished in chestnuts, acorns, \&cc. 3. Tegument. - The skin or barik of seeds; it separates from peas, beans, Indian corn, \&c., on boiling. 4. Hilum. - The external mark or sear on seeds, by which they were affixed to their pericarps. In beans and the like it is called the eye.

The receptacle is subdivided into -1 . Proper. - That which belongs to one flower only. 2. Common. - That which connects several distinct florets, as in the sunflower, daisy, and teasel. 3. Rachis. - The filiform receptacle, connecting the florets in a spike, as in the heads of wheat. 4. Columnella. - The central 
column in a capsule to which the seeds are attached. 5. Spadix. - An elongated receptacle proceeding from a spathe, as In dian turnip.

Flowers are divided into-1. Simple. - Having a single flower on a receptacle, as in the quince, tulip, \&c. 2. Aggregate. - Having on the same receptacle, several flowers, whose anthers are not united, as teasel, button-bush, \&c. 3. Compound. - Having several florets on the same receptacle, with their anthers united, as sunfl wer, China-aster. 4. Staminate. Having stamens, as those in he tassels of Indian corn. Pistillate. - Having pistils only, as the fertile flower of the cucumber. 6. Perfect. - Having both stamens and pistils. 7. Neutral. - Having neither stamens nor pistils.

Inforescence. - As to the manner in which flowers are situated on plants, there are -1 . Whorl... In which the flowers grow around the stem in rings, one above another, as motherwort and catnip. 2. Raceme. - Having the floret on short pedicels, arranged along a general peduncle, as currants. 3. Panicle. - Having some of the pedicels along the general peduncle of the raceme, divided, as oats. 4. Thyrse. - A panicle contracted into a compact, somewhat ovate form, as in lilac. 5. Spike. Having the florets sessile, or nearly so, on the elongated general receptacle, as wheat, mullein, \&c. 6. Umbel.-Having the flower-stems diverging from one place lize the braces of an umbrella, bearing florets on their extremities, as carrot, dill, fennel, \&c. 7. Cyme. - It agrees with the umbel in having its general flower-stem spring from one centre, but differs in having those stems irregularly subdivided, as elder, \&c. 8. Corymb. - The peduncles take their rise from different heights along the main stem; but, the lower ones being longer, they form nearly a level top, as yarrow. 9. Fascicle. - In general external appearance it resembles the umbel, but the footstalks are irregular in their origin and subdivisions, as the sweet-william. 10. Head. - The flowers are heaped together in a globular form, without peduncles, or with very short ones, as clover.

The substance of roots and herbage consịsts of -1 . Cutrcle. 
--The thin outside coat of the bark, which seems to be withcut life, and often transparent; very conspicuous in birch, \&cc. 2. Cellular Integument. - The substance between the cuticle and bark; often green, easily seen in the elder. 3. Bark. -- The inner strong fibrous part of the covering of vegetables. 4. Camb. The mucilaginous substance, which, in the spring of the year, abounds between the bark and the wood of trees. 5. Woot. - The most solid part of the trunks and roots of trees and herbs. 6. Pith.-The spongy substance in the centre of the stems and roots of most plants. Large in the elder.

Roots are the descending parts of vegetables, anil are annual, lasting one year; biennial, lasting two years; and perennial, lasting many years. They are of seven sorts -1 . Branching. - The whole root being divided into parts as it proceeds downward, as the oak, \&c. 2. Fibrous. - The whole root consisting of filiform parts, originating from the basie of the stem, as many of the grasses. 3. Creeping. - Extending itself horizontally, and sending out fibrous radicles, as mint, gill-overground, \&c. 4. Spindle. - Thick at the top, and tapering downward, as carrot, parsnip, \&c. 5. Tuberous. - Roots which are thick and fleshy, but not of a regular globular form; they are knobbed, as the potato, oval, as those of orchis, abrupt, as the birdsfootviolet, or fascicled, as asparagus. 6. Bulbous. - Fleshy and spherical; they are either solid, as the turnip, coated, as the onion, or scaly, as the garden-lily. 7. Granulated. - Consisting of several little kncbs in the form of grains, strung together along the sides of a filiform radicle, as the wood-sorrel.

The term herbage includes all the plant excepting the root and fructification. It includes the stems, leaves, and appendages. Of stems, we have the tidge, as the trunk of the oak, grape-vine, muinein, \&cc.; the culm, as the stem of wheat, grasses, sugarcane, \&c.; the scape, as the bare stem of the dandelion; the peduncle, as the flower-bearing stem of the apple-tree, cucumber-vine, \&c.; the petiole, the footstalk of the leaf; the frond: which applies entirely to cryptogacnous plants; and includes the substances from which the fruits are produced; the stipe, as the stem of a fern, of a fungus, a mushroom, \& $\&$ c. 
On the subject of leaves, including their forms, their edgres, their ends, their surfaces, their positions, their character, as simple or compound, with their appendages, the reader is referred to the writers on these points, and particularly to Thornton's "Grammar of Botany, with Plates."

The Linnæan system of botany divides all plants into twenty-four classes, which are farther divided into orders, the orders into genera, and the genera into species containing varieties. The characters of the classes are taken from the number, length, connexion, or situation of the stamens. The Linnæan classes are twenty-four, but have been reduced to twenty, which have been thus arranged:-

\section{TABLE OF CLASSES.}

1. Monandria; one stamen; Indian flowering reed.

2. Diandria ; two stamens; speedwell, sage.

3. TRIANDRIA; three stamens; saffron, the grasses.

4. Tetrandia; four stamens, equal in length; teasel, plantain.

5. Pentandria; five stamens, anthers not united; primrose, elm.

6. HexandRIA; sir stamens of the same length; daffodil, asparagus.

7. Heptandria ; segven stamens; wintergreen, horse-chestnut.

8. OCTANDRIA; elghit stamens; eardrop, willow-herb.

9. ENNEANDRIA; nine stamens; laurel, flowering rush.

10. Decandria; ten stamens, filaments not united; pink, wood-sorrel.

11. Dodecandria; twelve to nineteen stamens; houseleek, agrimony.

12. ICOSANDRIA; more than twelve stamens, fixed on the calyx or petals; mountain-ash, plum.

13. Polyandria; $t$ wenty to one thousand, fixed to the receptacle; crow. foot, poppy, piony.

14. Didynamia; four stamons, two long and two short; Virginian thyme, eyebright.

15. Tetrodynamia; six stamens, four long and two short; mustard, horseradish.

16. Monadeipmil ; the filaments united; geranium, mallow, cotton.

17. Diadelphia; in one or two sets, blossom butterfy shaped; bush and pole bean, pea.

18. PolyadelphiA; in three or more sets; yarrow, mayweed, burdock.

19. SZngenesia ; five stamens, anthers united, fowers compound; la. dy's slipper, sunflower.

20. Cryptogamia ; flowers with stamens obscure; moss, fern, mushrooin, liverwort. 
As a general view of the ORDERs in the Linnæan system, it is proper to remark that, in the fourteenth class, the orders depend upon the seeds having a seed-vessel or not. In the fifteenth class, they depend upon the shape or form of the seed-vessels. In the nineteenth class, they depend on the structure of the flo rets. In the twentieth class, they depend upon the natural assemblage of plants resembling each other. And in all the other classes, excepting the sixteenth, seventeenth, and eighteenth, the orders depend upon the number of pistils only. To determine the number of pistils, the styles must be counted, as they appear at their base; but if the summits are not supported by styles, then count the number of the summits.

The following is a brief view of the classes and orders in the Linnæan system, with examples of each order:--

\section{MONANDRIA.}

$\begin{array}{cll}\text { ORDER-Monagynia, } & 1 \text { pistil, } & \text { marestail, stonewort. } \\ \text { Digynia, } & 2 \text { pistils, } & \text { Indian weed, water-fennel. } \\ \text { Tetragynia, } & 4 \text { pistils, } & \text { pondweed. }\end{array}$

II. DIANDRIA.
Ordek-Monagyria, 1 pistil, Culver's physic, privet. Digynia, $\quad 2$ pistils, sweet-vernal-grass.

III. TRIANDRIA.

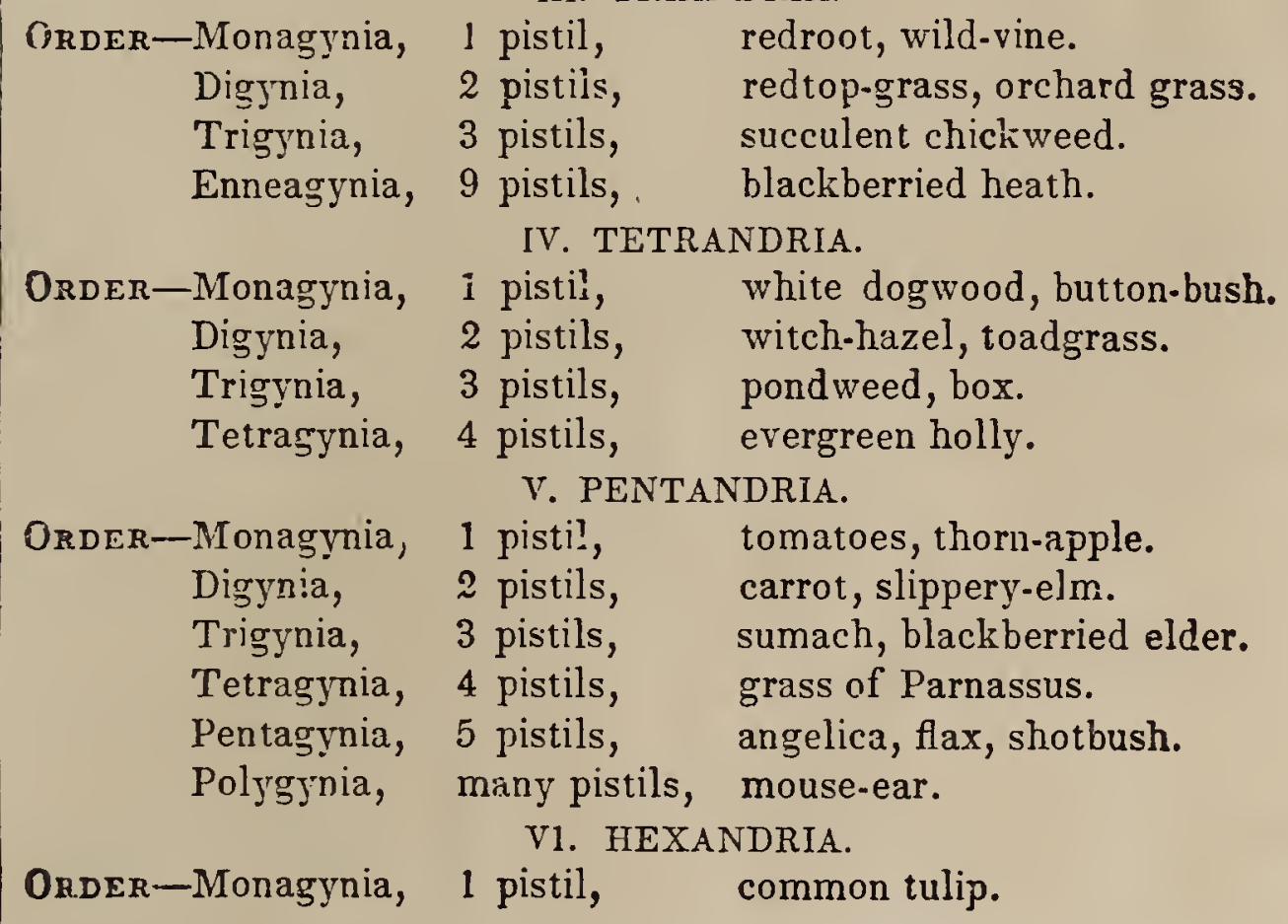




\begin{tabular}{|c|c|c|}
\hline 254 & \multicolumn{2}{|c|}{ BOTANY. } \\
\hline $\begin{array}{l}\text { ORDEP-Trygynia, } \\
\text { Pentagynia, } \\
\text { Pclygynia, }\end{array}$ & $\begin{array}{l}3 \text { pistils, } \\
5 \text { pistils, } \\
\text { many pistils, } \\
\text { viI. IIEPT. }\end{array}$ & $\begin{array}{l}\text { Indian poke, reratrum. dock. } \\
\text { marsh-rosemary. } \\
\text { water-plantain } \\
\text { WDRIA. }\end{array}$ \\
\hline ORDER-YIonagynia, & 1 pistil, & $\begin{array}{l}\text { horsechestnut, chick-wintergreen. } \\
\text { NDRIA. }\end{array}$ \\
\hline $\begin{array}{l}\text { Order-Monagynia, } \\
\text { Digrnia, } \\
\text { Trigynia, } \\
\text { Tetragynia, }\end{array}$ & $\begin{array}{l}1 \text { pistil, } \\
2 \text { pistils, } \\
3 \text { pistils, } \\
4 \text { pistils, } \\
\text { IX. ENNEA }\end{array}$ & $\begin{array}{l}\text { maple, cranberry, willow-herb. } \\
\text { fercrfew, garden chrysanthemum. } \\
\text { buckwheat, golden saxifrage. } \\
\text { waterwort, herb-paris. } \\
\text { NDRIA. }\end{array}$ \\
\hline $\begin{array}{l}\text { Order-Monagynia, } \\
\text { Digynia, } \\
\text { Trigynia, } \\
\text { Hexagynia, }\end{array}$ & $\begin{array}{l}1 \text { pistil, } \\
2 \text { pistils, } \\
3 \text { pistils, } \\
6 \text { pistils, } \\
\quad X . \text { DECAX }\end{array}$ & $\begin{array}{l}\text { sassafras, spice-bush. } \\
\text { dog-mercury. } \\
\text { rhubarb. } \\
\text { flowering-rush. } \\
\text { DRIA. }\end{array}$ \\
\hline $\begin{array}{l}\text { Order-Monaggnia, } \\
\text { Diggnia, } \\
\text { Trigynia, } \\
\text { Pentagynia, }\end{array}$ & $\begin{array}{l}1 \text { pistil, } \\
2 \text { pistuls, } \\
3 \text { pistils, } \\
5 \text { pistils, } \\
\quad \text { XI. DODEC. }\end{array}$ & $\begin{array}{l}\text { prince's pine, wild indigo. } \\
\text { sweet-william, London pride. } \\
\text { spurge, stickwort. } \\
\text { lire-for-ever, wood-sorrel. } \\
\text { ANDRIA. }\end{array}$ \\
\hline $\begin{array}{l}\text { ORDER-Monagynia, } \\
\text { Digynia, } \\
\text { Trigynis, } \\
\text { Dodecagynia, }\end{array}$ & $\begin{array}{l}1 \text { pistil, } \\
2 \text { pistils, } \\
3 \text { pistils, } \\
12 \text { pistils, } \\
\text { XII. ICOS } 1\end{array}$ & $\begin{array}{l}\text { white snakeroot. } \\
\text { agrimont. } \\
\text { euphorbia-spurge. } \\
\text { houseleek. } \\
\text { NDRIA. }\end{array}$ \\
\hline $\begin{array}{l}\text { Order-Monagynia, } \\
\text { Digynia, } \\
\text { Trigynia, } \\
\text { Pentagynia, } \\
\text { Polygynia, }\end{array}$ & $\begin{array}{l}1 \text { pistil, } \\
2 \text { pistils, } \\
3 \text { pistils, } \\
5 \text { pistils, } \\
\text { inany pistils, } \\
\text { XiI. POLY }\end{array}$ & $\begin{array}{l}\text { peach, plum. } \\
\text { queen of the meadow. } \\
\text { mountain-ash. } \\
\text { pear, thorn-bush. } \\
\text { rose, raspberry. } \\
\text { ANDRIA. }\end{array}$ \\
\hline $\begin{array}{l}\text { ORDER-Monagynia, } \\
\text { Digynia, } \\
\text { Trigynia, } \\
\text { Pentagynia, } \\
\text { Polygynia, }\end{array}$ & $\begin{array}{l}1 \text { pistil, } \\
2 \text { pistils, } \\
3 \text { pistils, } \\
5 \text { pistils, } \\
\text { many pistils, } \\
\quad \text { XIV. DIDY }\end{array}$ & $\begin{array}{l}\text { May-apple, bloodroot. } \\
\text { St.-John-wort. } \\
\text { larkspur. } \\
\text { monkshood, columbine. } \\
\text { goldthread, purple rirgill's bean. } \\
\text { NAMIA. }\end{array}$ \\
\hline $\begin{array}{r}\text { OrDER-Gymnospermia } \\
\text { Angiospermia, }\end{array}$ & $\begin{array}{l}\text { a, seeds liscore } \\
\text {, seeds corered, } \\
\text { XV. TETRAI }\end{array}$ & $\begin{array}{l}\text { red, motherwort, spearmint. } \\
\text { suapdragon, snakehead'd foxgiore }\end{array}$ \\
\hline $\begin{array}{l}\text { ORDER-Siloculosa, } \\
\text { Siliquona, } \\
\text { The flowers of this c }\end{array}$ & $\begin{array}{l}\text { pouch, or broa } \\
\text { long pod, } \\
\text { class hare alwa }\end{array}$ & $\begin{array}{l}\text { d pod, horseradish, peppergrasø. } \\
\text { turnip, wall-flower. } \\
\text { ts four petals. }\end{array}$ \\
\hline
\end{tabular}


XVI. MONADELPHIB.

ORDER-Triandria, 5 stamens, blue-eyed grass, juniper.

Decandria, 10 stamens, bloody-geranium, cranesbill.

Polyandria, manystamens, hollyhock, mallows.

In this class the filaments are together at the bottom, but separate at the top.

ORDER-Hexandria, 6 stamens, colic.weed, fumitory.

Octandria, 8 stamens, milkwort, flowering wintergreen.

Decandria, 10 stamens, upine, common pea.

ORDER-Polyanciria, XVIII. POLYDELPHIA.

common St.-John-wort.

XIX. SYNGENESIA.

ORDER-Polygamia equalis; florets furnished with stamens and pistils; dandelion.

Polygamia superflua; florets in the centre with stamens and pistils, in the circumference pistils only; southernwood, artemisia.

Polygamia frustanea; florets in the centre, with stamens and pistils, ${ }^{\prime}{ }_{1} n$ se in the circumference without any ; sunflower, blessed thistle.

Polygamia necessaria; florets in the centre, with stamens and pistils, but producing no seed - the pistils on the outside only having seed; marygold.

Polygamia segregata; separate florets; globe thistle.

This class comprehends the flowers called compound, theis anthers being united.

XX. CRYPTOGAMIA.

This class consists of those plants, in which the fructifications are ob. scure; and, therefore, do not fall under any of the preceding classes and of'ders. They have been divided into six orders :-

1. Miscellanea; including plants incapable of arrangement, as the horsetail.

2. Felices, or ferns; well known, as the spleenwort and polypody.

3. Musci, or the family of mosses; well known.

4. Algæ; comprising plants scarcely admitting of a dirision into root, stem, and leaf, such as lichens and seaweed.

5. Fungi; as funguses, comprising mushrooms, toadstools, \&c.

6. Hepaticæ; mosses distinguished from common mosses by a difference in the fructification.

Having given this brief view of the Linnæan division of the vegetable kingdom into classes and orders, the next thing to be 
noticed is, that plan's are farther divided into genera, and species, with their varieties. By species we understand individuals which compose the genera, or general family; and each of which has a specific name. And the genus comprehends several species, so essentially different in formation, nature, and some adventitious qualities, from other plants, as to constitute a distinct family or kind. To illustrate this distinction, we may refer to the fact, that, in the human race, some are distinguished from all others by a generic or family name, as Smith, White, Brown, \&c. But, in order to identify individuals in these families or genera, we have to give a specific name to euch individual: thus, when we refer to individuals or species in these families, we say, John Smith, Thomas Smith; or John White, Thomas White; or John Brown, Thomas Brown, \&c. Thus we have the genus in the family name, and the species in the name of the individual. It is just so in plants; the genus or family name rosa includes all roses; the genus salix or willow comprehends all willows; and the genus iris or fag includes all the flags.

The marks upon which the genera of plants are founded, are always taken from the shape, position, number, or some other property of the different parts of the flower, as the calyx, petals, seeds, seed-vessels, \&c., as whether they be round, or heartshaped; whole, or divided; rough, or smooth; single, or many; and the like. But the marks by which the species or individuals are known, are formed upon the leaves, stems, roots, or any other parts of the plant, except the flower. 


\section{FLORAL DICTIONARY.}

A.

AcAcIA : Platonic or Chaste Love. Acalea: Temperance.

Acanthus: The Arts.

Achilla Millefolia : War.

Aconite-leaved Crowfoot, or Fair Maids of France: Lustre.

African Marygold: Vulgar Minds.

Agnus Castus: Coldness; to live without Love.

Agrimony" Thankfulness.

Almond-Tree: Indiscretion, Heedlessness.

Almond-Laurel: Perfidy.

Aloe: Imagination.

Althæa Frutex: Persuasion.

Alyssum (Sweet): Worth beyond

Beauty.

A maranth: Immortality.

Amaryllis: Haughtiness, Pride.

Ambrosia: Love returned.

American Cowslip: You are my

Divinity.

A mericar Elm: Patriotism.

A merican Linden: Matrimony.

American Starwort: Welcome to a

Stranger.

Anemone: Your Frown I defy.
Anemone (Field): Sickness. Anemone (Garden): Forsaken. Angelica: Inspiration.

Angrec: Royalty.

Apocynum: Falsehood.

Apple-Blossom : Preference ; Fame speaks him great and good.

Arum or Wake-Robin: Ardour.

A Roseleaf: I will not trouble you. Asclepias: Cure for the Heartache.

Ash: Grandeur.

Ash-leaved Trumpet-Flower: Separation.

Aspen-Tree : Lamentation.

Asphodel: My regrets follow you to the Grave.

Auricula: Painting.

Azalea: Your Blush has won me.

\section{B.}

Bachelor's Button: I with the Morning's Love have oft maje Sport. Balm of Gilead: Healing; a Cure Balm (Gentle): Pleasantry.

Balsam : Impatience.

Barberry: Sharpness, Sourness.

Basil : Hatred. 
Bay-Berry : instruction.

Bay-Leaf: I change but in dying.

Bay-Wreath: Reward of Merit.

Bear's-Breech: Art.

Beech: Prosperity.

Belvidere: I declare against you.

Bee-Ophrys: Error

Betony: Surprise.

Bilberry: Treachery.

Birch: Gracefulness.

Bindweed: Humility.

Bird-Cherry: Hope.

Bırd's-Foot Trefoil: Rerenge.

Bearded Crepis : Protection.

Black Poplar: Courage.

Black-Thorn: Difficulty.

Bladdernut-Tree: Frivo_ous A musements.

Blue-Bottie Centaury: Delicacr.

Blue.Flowered Greek Valeriun: Pupture.

Blue Canterbury Bell: Constancy.

Bonus Henricus: Goodness.

Borage: Bluntness or Roughness of Marmers.

Box: Stoicism.

Bramble: Enry.

Branch of Currants: You pleasc all.

Branch of Thorns: Severity, Rig. our.

Broken Straw: Dissension, Rupture.

Broom: Mirth, Ncatness.

Bryouly: Prosperity.

Buckbean : Flattcry's Smile; Calm Repose.

Bud of a White Rosc: A IIcart if. norant of Love.

Burgloss: Falsehood.

Burdock: Importunity.

Bundlc of Reeds with thpir Frril cles: Music.

Puttercups: Ing̣ratitude.
Butterfy-Ophrys: Gayety.

Butterfy.Weed: Let me go.

C.

Cabbage : Profit.

Calla ( Ethiopica) : Feminine Mod. esty.

Calycanthus: Benevolence.

Camomile: Energy in Adversity.

Campanula : Gratitude.

Canary-Glass : Pcrseverance.

Candy-Tuít : Indifferencc.

Canterbury Bell (Blue): Constanc..

Cardamine : Paternal Frror.

Catesby's Starwort: Afterthought.

Cardinal's Flowcr: Distinction.

Catalpa-Tree: Beware of the Co. quette.

Catchfl: : Snare.

Cedar of Lebanon: Incorruptible.

Cedar-Tree: Strength.

Chechered Fritillary: Persecution.

Cherry-Tree: Good Education.

Cherry-Blossom: Spiritual Beauty.

Chestnut-Tree: Do me Justice.

China-Aster, or Chinese Starwort: Variety.

China or Indian Pink: A rersion.

China or Monthly Rose: Beauty ever new.

Chinese Chrysanthemum: Cheerfulness under Adversity.

Cinquefoil: Parental Love.

Cistus, or Rocli-Rose: Popular Fa. vour.

Circæa: Fascination.

Clematis: Artifice.

Clove-Gillyflowcr: Dignity.

Cobca: Gossip.

Cocli's Comb, or Crested A maranth: Singularity.

Colchicum or Mcadow-SafTron : MY besi Daỵs are past. 
Coltsfoot: Justice shall be done you.

Columbine : Folly.

Common Cactus, or Indian Fig: I burn.

Common Fumitory: Spleen.

Common Milfoil : War.

Common Reed: Complaisance.

Common Tijsstle: Importunity.

Convolvulus Major: Extinguished Hopes.

Convolvulus Minor: Night.

Corchorus : Impatience of Absence.

Curn: Riches.

Cornelian Cherry-Tree : Durability.

Coreopsis : Love at first Sight.

Coriander: Concealed Merit.

Coronilla: Success crown your Wishes.

Cowslip: Pensiveness.

Cranberry: Hardiness.

Creeping Cereus: Horror.

Crocus: Smiles, Cheerfulness.

Cross of Jerusalem: Devotion.

Crown Imperial: Majesty and Power.

Cuckoo-Pink: Ardour.

Cyclamen: Diffidence.

Cypress: Mourning.

Cypress and Marygold: Despair.

Cypress-Tree: Death and eternal Sorrow.

D.

Daffodil: Deceitful Hope.

Dahlia: Heartless Beauty; Instability.

Daisy: Innocence.

Daisy (Garden): I partake your Sentiments.

Daisy (White) : I will think of it. Damask Rose: Freshness of Com. plexion.

Dandelion: Oracle.
Daphne Odora: Sweets to the Sweet.

Darnel, or Ray Grass : Vice.

Dew-Plant: A Serenade.

Dead Leaves: Sadness.

Dignity in Misfortune: Rosebay.

Dittany: Birth.

Dodder: Baseness.

Dragon-Plant: Snare.

Dried Flax: Utility.

E.

Ebony: Hypocrisy.

Elder: Zealousness

Elm: Dignity.

Enchanter's Nightshade: Fascination, Witchcraft.

Endive : Frugality.

Eupatorium: Delay.

Evergreen: Poverty.

Evergreen-Thorn: Solace in $A d$. versity.

Everlasting: Never ceasing hemembrance.

Everlasting Pea: Lasting Pleasure.

F.

Fennel: Strength.

Fern: Sincerity.

Fern (Flowering): Revery。

Fig : Argument.

Fig-Tree : Prolific.

Filbert: Reconciliation.

Fir : Time.

Fir-Tree : Elevation.

Flax: I feel your kindness.

Flax-leaved Goldy-Locks: Tardi. ress.

Flora's Beil : You are without Pre. tension.

Flower of an Hour : Delicate Beauty.

Flowering Reed: Confidence in Heaven. 
Forget-me-not: True Love.

Fairy's Glove, or Fnxglove: I am not changed - they wrong me. Frankincense: The Incense of a faithful Heart.

Fraxinella : Fire.

French Honeysuckle: Rustic Beauty.

French Marygold: Jealousy. Frog-Ophrys : Disgust.

Full-blown Eglantine: Simplicity. Fullers' Teasel: Austerity.

G.

Garden Chervil : Sincerity. Garden Marygold: Uneasiness.

Garden Ranunculus: You are rich in Attractions.

Garden Sage: Esteem.

Garland of Roses : Reward of Virtue.

Gentiana Fritillaria: Virgin Pride. Geranium (Sorrowful) : Melancholy Spirit.

Gilly-Flower: Lasting Beauty.

Glory-Flower: Glorious Beauty.

Goats' Rue: Reason.

Golden Rod: Precaution

Gorse: Cheerfulness in Adversity.

Goosefont: Goodness.

Grape (Wild) : Charity.

Grass : Utility.

Great Bindweed: Dangerous Insinuation.

Guelder Rose: Winter or Age.

H.

Yrarehell: Delicate and loneiy as this Flower.

Yawlrweed: Quicksightedness.

Gawhorn: Hope.

Hazel: Reconci iation.

Heath: Solitude.

Helenia : Tears.
Hellebore: Calumny.

Hemlock: You will cause my Death.

Henbane: Imperfection.

Hepatica : Confidence.

Hibiscus: Delicate Beauty.

Hickory : Glory.

Hoarhound: Frozen Kindness.

Holly: Foresight.

Hollyhock : Fecundity.

Honesty: Honesty.

Honeysuckle: Bond of Love.

Hop: Injustice.

Hornbeam : Ornament.

Horse-Chestnut : Luxury.

Hortensia : You are cold.

Houstonia: Content.

Hoya : Sculpture.

Hundred-leaved Rose: Graces.

Hyacinth: Grief.

Hydranger : Boaster.

I.

Iceland Moss: Health.

Ice-Plant: Your Looks freeze me. Indian Cress: Resignation.

Indian Jasmine : I attach myself to you.

Iris: Message.

Ivy : Friendship.

\section{J.}

Jacob's Ladder: Come down to me.

Japan Rose: Beauty is your only Attraction.

Jessamine, or Jasmine : Amiability.

Jessamine (Virginian): Soul of my Soul.

Jonquil: Desire.

Judas-Tree : Unbelief.

Juniper : Protectiol.

Justicia: The Perfection of Femare

Loveliness. 
K.

Kennedia: Mental Beauty.

King-Cup : I wish I was rich.

L.

Laburnum: Pensive Beauty.

Lady's Slipper: Win me and wear me.

Larch : Boldness.

Larkspur : Levity.

Laurel: Glory.

Laurustinus : I die if neglected.

Lavender: Assiduity.

Lemon: Zest.

Lettuce : Coldhearted.

Lichen: Solitude.

Lilac: First Emotion of Love.

Lilac (White): Youth.

Lily of the Valley : Return of Hap. piness.

Lime or Linden Tree: Conjugal Love.

Live Oak: Liberty.

Lobelia: Splendour.

Locust: Vicissitude.

London-Pride: Frivolity.

Lotus-Flower: Silence.

Love in a Mist : Perplexity.

Love in a Puzzle: Embarrassinent.

Love lies a-Bleeding: Hopeless, not Heartless.

Lucern: Life.

Lupine: Voraciousness.

Lychnis: Religious Enthusiasm.

Lythrum: Pretension.

M.

Madder : Calumny.

Madwort (Rock): Tranquillity.

Maiden-Hair: Discretion, Secrecy. Maize: Plenty.

Magnolia: Peerless and Proud. Mallow: Mild or sweet Disposition. Manchineel-Tree: Falsehood.
Mandrake: Rarity.

Maple: Reserve.

Marjorum: Blushes.

Marshmallow: Humanity.

Marvel of Peru: Timidity.

Marygold : Inquietude.

Marygold (Small-Cape): Presige.

May Rose : Precocity.

Meadow Saffron: My best Days are past.

Meadow.Sweet: Uselessness.

Mercury: Goodness.

Mesembryanthemum : Idleness.

Mezereon : Love in a Snow.Wreäı.h.

Michaelmas Daisy: Farewell.

Mignionette: Your Qualities surpass your Charms.

Milk-Vetch: Your Presence softens my Pain.

Mimosa: Sensitiveness.

Mint : Virtue.

Mistletoe: I surmount all Difficulties.

Mock Orange : Counterfeit.

Monk's Hood : Knight-Errantry.

Moonwort: Forgetfulness.

Moschatel: Wuak but winning.

Moss (Tuft of) : Maternal Love.

Moss-Rose: Pleasure without alloy.

Mossy Saxifrage: Maternal Love. Motherwort: Secret Love.

Mountain-Ash: Prudence.

Mouse-Ear Chickweed: Ingenious Simplicity.

Moving Plant: Agitation.

Mulberry-Tree (White): Wisdom.

Mulberry-Tree (Black) : I will rot survive you.

Mushroom: Suspicion.

Musk-Crowfoot: Weakness.

Musk-Rose: Capricious Beauty.

Myosotis, or Mouse-Ear : Forgetme-not. 
Myrobalan: Privation.

Myrlle: Lore.

\section{N.}

Narcissus (False): Delusive Hope. Narcissus (Poets') : Egotism.

Nasturtium: Patriotism.

Nettle: Cruelty.

Nigh Blowing Cereus: Transient Beauty.

Nightshade (Bitter-Sweet): Truth. Nosegay: Gallantry.

O.

Oak: Hospitality.

Oats : The witching Soul of Music, hers.

Oleander: Beware.

Olive: Peace.

Orchin: A Belle.

Orange-Flowers: Chastity. Orange-Tree: Generosity.

Osier: Frankness.

Ox-Eye: Obstacle.

\section{P.}

Palm: Victory.

Pansy, or Heart's-Ease: Think of me.

Parsley: Entertainment, Feasting.

Passion-Flower: Religious Superstition.

Patience Dock: Patience. -

Pasque-Flower: You are without Pretension.

Pea: An appointed Meeting.

Peach-Blossom: I am your Captive.

Pennyroỵal: Flee away.

Peony: Bashful Shame.

Pepper-Plant: Satire.

Periwinkle: Sweet Remembrances.

Persimon: Bury me amid Nature's

Beauties.

Persicaria: Restoration.

Peruvian Heliotrcpe: I trust in thee.

Pheasant's-Eye, or Flos Adonis: Sorrowful Remembrances.

Phlox: Unanimity.

Pimpernel: Assignation.

Pine: Pity.

Pine-Apple: You are perfect.

Pink: Lovely and pure Affection.

Plane-Tree: Genius.

Plum-Tree: Keep your Promises.

Plum-Tree (Wild): Independence.

Polyanthus: Confidence.

Potato: Beneficence.

Po megranate: Foolishness.

Poppy: Consolation of Sleep.

Prickly Pear: Satire.

Pride of China: Discussion.

Irimrose: Early Youth.

Primrose (Erening): Inconstancy.

Privet : Prohibition.

Purple Clover: Provident.

Pyramidal Bell-Flower: Gratitude. Pyrus Japonica: Fairies' Fire.

Q.

Quamoclet : Busybody.

Queen's Rocket: You are the Queen of Coquettes.

Ragged Robin: Wit.

Ranunculus: You are radiant with Charms.

Red Bay: Lore's Memory.

Red Mulberry: Wisdom.

Red Shanks: Patience.

Rest-Harrow: Obstacle.

Rhododendron: Danger.

Rocket . Rivalry.

Rose Beauty.

Rose (Wild) Simplicity.

Rose (Acacia): Elegance.

Rosebud: Youthful Charrs. 
Roses ( $\Lambda$ Garland of) : Reward of Virtue.

Rosebay Willow-Herb: Celibacy. Rose Campion: You are without Pretension.

Rosemary: Your Presence revives me.

Rose scented Geranium: Preference.

Rudbeckia : Justice.

Rue : Grace or Purification.

Rush : Docility.

S.

Saffron-Flower: Excess is Dangerous.

Saffron Crocus: Mirth.

Sage : Esteem.

Sardony: Irony.

Scabius: Unfortunate Attachrnent. Scarlet Fuchsia: Taste.

Scarlet Ipomœa, or Indian Jasmine : I attach myself to you.

Scotch Fir: Elevation.

Sensitive Plant: Timidity.

Serpentine Cactus: Horror.

Service-Tree : Prudence.

Shaking Saintfoin: Agitation.

Sibcrian Crab-Tree-Blossom : Deeply interesting.

$\mathrm{S}$ desaddle Flower: Will you pledge me?

Silver Fir : Elevation.

Small Bindweed: Obstinacy.

Small White Violet: Candour and Innocence.

Snapdragon: You are dazzling but dangerous.

Snowball: Thoughts of Heaven. Snowdrop: Consolation.

Sorrel: Wit ill-timed.

Southern-Wood: Jest or bantering. Spanish Jasmine: Sensuality. Spider-Ophrys : Skill. Adroitness. Spide"wort: Transient Happiness.
Spindle-Tree: Your Image is engraven on my Heart.

Spiked Speedwell: Resemblance.

Spiræ Hypericum Frutex: Useless. ness.

Squirting Cucumber : Critic.

St.-John's-wort: Superstitious Sanctity.

Star of Bethlehem: The Light of our path; Follow me.

Stock, or Gilly Flower: Lasting Beauty.

Stramonium (Common): Disguise. Strawberry: Perfect Excellence.

Striped Pink : Refusal.

Sumach: Splendour.

Sunflower: Smile on me still.

Swallowwort: Medicine.

Sweet Briar, or Eglantine: Poetry.

Sweet Flag: Fitness.

Sweet Pea: Delicate Pleasure.

Sweet Soltan: Felicity.

Sweet-scented Tussilage: You shall have Justice.

Sweet Violet: Modesty.

Sweet-William : Craftiness.

Sycamore: Woodland Beauty.

Syringa: Memory.

$\mathrm{T}$.

Tamarisk : Crime.

Tansy : Resistance.

Teasel: Misanthropy.

Ten-Weeks'-Stock: Promptitule.

Thistle: Austerity.

Thorn-Apple: Deceitful Charms.

Thrift: Sympathy.

Throatwort: Neglected Beauty.

Thyme: Activity.

Tremella Nostoc: Resolve the Riddle.

Truffle: Surprise.

Tiger-Flower : For once may Pride befriend me. 
Tree of Life: Old Agc.

Tuft of Moss : Maternal Love. Tulip: Declaration of Love.

Turnip: Charity.

\section{$\mathrm{V}$.}

Valerian (Red): Accommodating Disposition.

Various-coloured Lantana: Rigour.

Verbena: Sensibility.

Vernal Grass: Po or but happy.

Vervain : Enchantment.

Venus's Car: Fly with me.

Venus's Flytrap: Have I caught you at last.

Venus's Looking-Glass : Flattery.

Vine: Iutoxication.

Violet: Modesty.

Virgin's Bower : Artifice.

Virginian Spiderwort: Momentary Happiness.

Volkamenica Japonica: May you be happy.

W.

Wall-Flower: Fidelity in Adrersity.

Wall-Speedwell : Fidelity.

Water-Lily: Eloquence.

Walnut : Intellect.

Walking-Leaf: How came you here?

Watermelon : Bulkiness.

Water-Star : Beauty combined with Piety.

Wax-Plant: Susceptibility.
Wax-Myrtle: I will enlighten you. Weeping-Willow: Melancholy. Wheat: Riches.

While Jasmine: Amiableness.

White Lilac: Youth.

White Lily: Purity and Modesty.

White Mullein: Good Nature.

White Oak: Independence.

White Pink: Talent.

White Poplar: Time.

White Poppy: Sleep of the Heart. White Rose: Silence.

White Rose (Dried) : Death prefer. able to Loss of Innocence.

White Rosebud: The Heart that knows not Love.

White Violet: Candour.

Wild or Dog Rose: Simplicitv

Willow: Forsaken.

Willow-Herb: Pretension.

Winter-Cherry : Deception

Witch-Hazel: A Spell.

Wood-Sorrel : Joy.

Wormwood: Absence.

$\mathrm{Y}$.

Yarrow: War.

Yellow Carnation: Disdain.

Yellow Day-Lily: Coquetry.

Yellow Gentian : Ingratitude.

Yellow Iris : Flame.

Yellow Rose: Infidelity.

Yew : Sorrow.

$\mathrm{Z}$.

Zinnia: Absence. 
A.

A Belle: Orchis.

A'ssence: Wormwood, Zinnia.

Accommodating Disposition: Red

Valerian.

Activity: Thyme.

Afterthonght: Catesby's Starwort. Agitation: Moving Plant.

Amiability: Jessamine, or Jasmine. An appointed Meeting: Pea.

Arciour: Cuckoo-Plant; Arum, or

Wake-Robin.

Argument: Fig.

Art: Bear's-Breach.

Artifice : Virgin's Bower: Climatis.

A spell: Witch-Hazel.

Assiduity: Lavender.

Assignation: Pimpernel.

Attachment: Scarlet-flowered Ipomœa.

Austerity: Fullers' Teasel; Thistle.

Aversion: China or Indian Pink.

\section{B.}

Baseness : Dodder.

Bashful Shame: Peony.

Beauty: Rose.

Beauty combined with Piety: Wa. ter-Star.

Beauty ever new: China or Monthly Rose.

Beauty is your only Attraction : Japan Rose.

Beneficence: Potato.

Benevolence: Calycanthus.

Beware: Oleander.

Beware of the Coquette: Catalpa.

Tree.

Birth: Dittany.

$B^{\text {l }}$.ntness of Manners: Borage.

Bushes: Marjorum.

Boaster: Hydranger.

Boldness : Larch.
Bond of Love: Honeysuckle.

Bulkiness: Watermelon.

Bury me amid Nature's Beauties:

Persimon.

Busybody : Quamoclet.

C.

Calumny: Hellebore, Madder.

Candour aud Innocence: Sweet White Violet.

Capricious Beauty: Musk-Rose. Celibacy: Rosebay Willow-Herb. Charity: Wild Grape, Turnip.

Chastity: Orange-Flower.

Cheerfulness: Crocus.

Cheerfulness in Adversity: Chinese Chrysanthemum; Gorse.

Coldhearted: Lettuce.

Coldness; To live without Love: Agnus Castus.

Come down to me: Jacob's Ladder. Complaisance: Common Reed.

Concealed Merit: Coriander.

Confidence: Hepatica, Polyanthus.

Confidence in Heaven: Flowering Reed.

Conjugal Love: Lime or Linden Tree.

Consolation: Snowdrop.

Consolation of Sleep: Poppy.

Constancy: Canterbury Blue-Bell.

Content: Houstonia.

Coquetry: Yellow Day-Lily.

Counterfeit: Mock Orange.

Courage: Black Poplar.

Craftiness: Sweet-William.

Crime : Tamarisl.

Critic: Squirting Cucumber.

Cruelty: Nettle.

Cure (A): Balm.

Cure for the Heartache: Asclenias

D.

Danger: Rhododendron. 
Dangerous Insinuation: Great Bind. weed.

Death and eternal Sorrow : Cypress. Tree.

Death preferable to Loss of Inno. cence: White Rnse (Dried).

Deceltful Charms: Thorn.AIple.

Deceitlul Hope: Datfodil.

Deception: Winter-Cherry.

Declaration of Love: Tulin.

Deeply interesting: Siberian Crab. Tree-Blossom.

Delay: Eupatorium.

Delicacy: Blue-Bottle Centaury.

Delicate and Lovely as thus Flower : Harebell.

Delicate Beauty: Hibiscus.

Delicate Pleasure: Sweet Pea.

Drlusive Hope: False Narcissus.

Desire: Jonquil.

Despair: Marygnld and Cypress.

Devntion: Cross of Jerusalem.

Difficulty: Black Thorn.

Diffidence: Cyclanien.

Dignity : Clove-Gillyflower.

Discretinn, Secrecy: Malden-Hair.

Disidain : Yellow Carmation.

Dinguise: Common Stramonium.

Disgust: Frog-Ophrys.

Dissensinn: Pride of China.

Dissension, Rupture: Broken Straw.

Distinction: Cardınal's Flower.

Docility : Rush.

Do me Jistice: Chestnut.Tree.

Durability: Cornelian-Cherry-Tree.

E.

Early Youth: Primrose.

E.gntısm: Poets' Narcissus.

Elegance: Acacia Rose.

Elevation: Fir-Tree.

Einquence: Iris, Water.Li'y.

Einbarrassment: Love in a Puzzle. Enchautment : Vervain.
Energy in Adversity: Camomile. Emul: Moss.

Eutertainment, Feasting: Part $\ln y$.

Envy: Bramble.

Eirror: Ber-(Ophrys.

Esteem: Sage.

Excess is Dangerous: Saffron-Flow. er.

Extinguished Hopes: Convovulus Major.

F.

Fair within, though cold in seem. ing: The Dew-Plant.

Falsehood: Bugloss, Manchincel. Tree.

Fancy's Fire: Night-Blowing Cere. us.

Fame speaks him great and good: A pple-BInssom.

Farewell: Michael mas-Daisy.

Fuscination: Enchanter's Night. sharle.

Fecundity: Hollyhock.

Felicity: Sweet soltan.

Feminue Modesty: Calla Ethiopica.

Fidelity: Wall-Speedwell.

Fidelity in Adversity: Wall.Flow. er.

Finesse: Sweet-William.

Fire: Fraxinella.

First Emotion of Love: Lilac.

Fitness : Sweet Flag.

Flane: Yellow Iris.

Flattery's Smile: Buclibean.

Flattery : Venus's Lonkmg.Glass.

Flee away: Pennyroyal.

Fly with me: Venus's Car.

Follow me; The Light of our vath:

Star of Bethlehem.

Folly: Columbine.

Foolishness: Ponnegianate

Foresight: Holly. 
Forgetfulness: Mnonwort.

Forget me not: Myosotis or MouseFiar.

For once may Pride befriend me: Tiger-Flower.

Forsaken: Garden Anemone, Willow.

Frankness: Osier.

Freshness of Complexion: Damask Rose.

Friendship: Acacia Rose; Ivy.

Frivolity: London Pride.

Frivolnus Amusements: Bladdernut-Tree.

Frnzen Kindness: Hoarhound.

Frugality: Endive.

\section{G.}

Gayety: Butterfly.Ophrys.

Gallintiry: Nosegay.

Gelterosty: Orange-Tree.

Geimus: Plane-Tree.

Glurious Beauty: Glory-Flower.

Ginry: Laurel.

Grool Eiducation: Cherry-Tree.

Gond Nature: White Mullem.

Gonduess: Guod Henry; Goosefont.

rossip: Cohora.

Graces: Ilundred-leaved Rose.

Ciracefuluess: Birch.

Grantleur: A-h.

Gratıtude: Pyra nidal Bell.Flower. Grief: Hyacinth.

II.

IIardiness : Cranberry.

Hatred : Basil.

Haurhtumes or Pride: A maryllis.

Have I caught you at last? Venus's Flytrap.

Healmg; A Cure: Balm of Gllead. Health: Icelanil Mlows.

Heartless Beauty: Dahlia.
Honesty: Honesiy.

Hope: Hawthorn.

Hopeless, not Hearlless : Love lies a-Bleeding.

Horror: Serpentine Cactus.

Hospitality: Oak.

How came you here? Walking. Leaf.

Humanity: Marshmallow.

Humility : Bındweed.

Hypocrisy : Ebony.

I.

I am not changed - they wrong me: Farry's Glove, or Foxglnve.

I am your Captive: Peach-BInssom.

I attach myself to you: Scarlet I pomoea, or Indian Jasnime.

I burn: Common Cactus.

I change but in dying: Bay-Leaf.

I declare against you: Belvidere.

I die if neglected: Laurustinus.

Idleness : Fig Marygold.

I feel your kindness: Flax.

Imagination: Aloe.

Imunortality: Amaranth.

Impatience: Balsam.

Impatience of Absence: Corchorus.

Inperfectinn: Henbane.

Linpenrtunity: Common Thistle, Burdock.

Inconstancy: Evening Primrose.

Incorruptible: Cedar of Lebanon.

Indepentence: White Oak; Wild

Plum-Tree.

Indifference : Candr-Tuft.

Indiscretinn, Heedlessness: Al. mond-Tree.

Infidelity: Yellow Rose.

Ingenunus Sumplicity: Mouse-Ear Cluckweed.

Ingratıtude: Yellow Gentian; But. tercups.

Injustice : Hops. 
Innocence : Daisy.

Inquietude : Marygold.

Inspiration: Angelica.

Instruction: Bay.Berry.

Intellect : Walnut.

Intoxication: Vine.

I partake your Sentiments: Garden Daisy.

Irony: Sardony.

I surmount all Difficulties: Mistletoe.

I trust in the : Perurian Heliotrope.

I will enlighten you: Wax-Myrtle.

I will not survive you: Black-Mulberry-Tree.

I will not trouble you: A Roseleaf. I will think of it: White Daisy.

I with the Morning's Love have oft made Sport : Bachelor's Button.

I wish I was rich: King-Cup.

I.

Jealousy: French Marygold.

Jest or bantering : Southern-Wood. Joy: Wood-Sorrel.

Justice : Rudbeckia.

Coltsfoot: Justice shall be done you.

K.

Keep your Promises: Plum-Tree. Knight-Errantry: Monk's Hood.

\section{I.}

Lamentation: Aspen-Tree.

Lasting Beauty: Stock, or GillyFlower.

Lasting Pleasure: Everlasting Pea. Liberty : Live Oak.

Life : Lucern.

Let me go: Butterfly-Weed.

Levity : Larkspur.

Lirely and pure Affection: Pink. Love : Myrtle.
Love at first Sight: Coreopsis.

Love in a Snow.Wreath: Mezerc. on.

Love Returned: Ambrosia.

Love's Memory : Red-Bay.

Love Match: London Pride.

Lustre : Aconite-leaved Crowfoot.

Lusury : Horse-Chestnut.

M.

Majesty and Power: Crown Imperial.

Maternal Love: Tuft of Moss.

Matrimony: American Linden.

May you be happy: Volkamenica Japonica.

Medicine: Swallowwort.

Meekness with Dignity : Plumbago.

Melancholy: Weeping.Willow.

Melancholy Spirit: Sorrowful Ge. ranium.

Memory : Syringa.

Mental Beauty : Kennedia.

Message: Iris.

Mirth: Safiron Crocus; Broom.

Misanthropy: Teasel.

Modesty: Violet.

Momentary Happiness: Virginian Spiderwort.

Mourning: Cypress.

Music: Bundles of Reeds with Panicles.

My best Days are past: MeadowSafiron.

My Heart bleeds for you : Camellia Japonica.

My Regrets will follow you to the Grave: Asphodel.

\section{N.}

Necessitude : Locust.

Neglected Beauty: Throatwort.

Never-ceasing Remembrance: Er. erlasting. 
Night : Lonvolvulus Minor, or Night Convolvulus.

0.

Obstacle : Ox-Eye, Rest-Harrow. Obstinacy: Small Bindweed. Old Age: Tree of Life. Oracle : Dandelion. Ornament: Hornbeam.

\section{P.}

Painting: Auricula.

Parental Love: Cinquefoil.

Paternal Error: Lady's Smock. Patience: Red Shanks; Patience Dock.

Patriotism: Nasturtium.

Peace : Olive.

Peerless and Proud: Magnolia.

Pensive Beauty : Laburnum.

Pensiveness: Cowslip.

Perfect Excellence: Strawberry.

Perfidy: Almond-Laurel.

Perplexity : Love in a Mist.

Persecution: Checkered Fritillary.

Perseverance : Canary Glass.

Persuasion: Althæa Frutex.

Pity : Pine.

Platonic or chaste Love: Acacia.

Pleasure without Alloy: Moss-

Rose.

Plenty: Maize.

Poetry: Sweet Brier, or Eglantine.

Poor but happy : Vernal Grass.

Popular Favour: Cistus.

Poverty : Evergreen Clematis.

Precaution: Golden Rod.

Precocity: May-Rose.

Preference: Rose-scented Geranium; Apple-Blossom.

Presage: Small-Cape Marygold. Pretension: Willow-Herb, Lythrum. Privation: Myrobalum.

Profit: Cabbage.
Prohibition: Privet.

Prolific: Fig-Tree.

Promptitude: Ten-Weeks'-Stock.

Prosperity: Bryony.

Protection: Juniper.

Provident: Purple Clover.

Prudence : Service-Tree, MountainAsh.

Purification or Grace : Rue.

Purity and Modesty: White Lily.

Q.

Quicissightedness: Hawkweed.

R.

Rarity: Mandrake.

Reason: Goat's Rue.

Reconciliation: Filbert.

Refusal ; Striped Pink.

Religious Enthusiasm: Lychnis.

Religious Superstition: Passion. Flower.

Resemblance: Spiked Speedwell.

Reserve: Maple.

Resignation: Indian Cress.

Resistance : Tansy.

Resolve the Riddle: Tremella Nostoc.

Restoration : Persicaria.

Return of Happiness: Lily of the Valley.

Revenge: Birdsfoot Trefoil.

Revery : Flowering Fern.

Reward of Virtue: A Garland of Roses.

Reward of Merit: Bay-Wreath.

Riches : Corn, Wheat.

Rigour: Various-coloured Lantana.

Rivalry: Rocket.

Rosebay; Dignity in Misfortune.

Royalty: Angrec.

Rupture, Dissension: Broken Straw.

Rustic Beauty: French Honeysuc. kle. 
S.

Sadness: Dead Leaves.

Sature: Pelprir-Plant.

Sculpture: llogra.

Secrecy, Discretion: Maiden-Hair.

Secret Love: Molherwort.

Sensibility: Verbena.

Sensituveness: Mımosa.

Sensuality : Spanısh Jasmine.

Separation: Ash-leaved Trumpet Flower.

Soul of My Soul: Virginian Jasmine.

Serenarle: Dew.Plant.

Severity: Branch of Thorns.

Sharpness, Sourness : Barberry.

She will be Fashionable: Queen's Rocket.

Sickness: Field Anemone.

silence: White Rose.

Simplicity: Wild or Dong Rose.

Sincerty: Fern; Garden Chervil.

Singularity: Crested Amaranth.

skill, Adrottness: Spider-Ophrys.

Sleep of the Heart: Waite Polyy.

simules: Crocus.

Sulle on me stull: Sunflower.

Sialre: Dragon-Plant, Catch-Fly.

Solace in Adversity: Evergreen Thorn.

Solitude: Heath.

Sorrow: Yew.

Sorrowfnl Remembrances: Pheasant's kye, or Flos Adonis.

Spiritual Beauty: Cherry-Tree-Blossom.

Splendour: Lohelia, Sumach.

Spiren: Common Fumutury.

Storcisin: Box.

sirmeth: Cedar.Tree, Fennel.

Suhmission: lirass.

Success crown your Wishes: Coronilla.
Suy"rstitious Sanctity: St.John'swort.

Surprise: Betony, Trume.

Susceptubiluty: Wax.Plant.

Suspicion: Mushirooun.

Sweet or mild Disposition: Mal low.

Sweel Remembrances: Periwin k.e.

Sweets to the Sweet: Daphne Odora.

Sympathy: Thrift.

T.

Talent: White Punk.

Tardmess: Flax-leaved Golly. Locks.

Taste: Scarlet Fuchsia.

Tears: Helenium.

Thankfulness : A grimony.

The Arts: Acanthus.

The Heart that knows not Love: White Rosebud.

The Incense of a faithful Heart: Frankincense.

The Light of our Path; Follow me: Star of Bethlehem.

The Perfection of human Loveliness : Justicia.

The witching Soul of Music, hers: Oats.

Think of me: Pansy or Heart's. Ease.

Thoughts of Heaven: Snowball. Time: White Poplar.

Timidity: Marvel of Peru; Sens: tive Plant.

Token: Laurentinus.

Tranqullity: Rock-Madwort.

Transinut Happmess: spucerwort

Treachery: Billberry.

Treason: Whortcberry.

True Love: Forget-me-not.

Truth: Bittersweet-Nightshade. 
U.

ITnanimity: Phlox.

Unhellef: Judas. Tree.

Unrasmess : Garden-Marygold.

Unfortumate Attachnent: Scabius.

Us lessness : Spuræ Hypericum Fru-

tex.

I tillty: Dried Flax; Grass.

V.

Varlety: China-Aster.

Vice: Darnel or Rdy Grass.

Victory: Palm.

Virgin Pride: Gentiana Fritillaria.

Virme: Miut.

Volupturusness: Tuberose.

Vuracionsness: Lupill.

Vulgar Minds: Afrıcan Marygold.

W.

War: Common Milfoil; Yarrow.

Weak hut winning: Mnschatel.

Weakness: Musk-Crowfont.

Welcome to a stranger: American starwort.

Will you pledge me? SidesaddleFlower.

W'n me and wear ne: Lady's Slipper.

W.nter: Guelder-Rose.

W، siom: Whute Mulberry-Tree.

Writ: Ragged Rohin.

Wit Ill-timed: Sorrel.

Woodland Beauty : Sycamore.

Wnrth beyond Beauty: Alyssum (Sweet).
Y.

You are cold: Hortensia.

You are dazzlmg but dangerous:

Snapulragon.

You are my Divinity: American

Cowslip.

You are perfect: Pine.Apple.

You are radiant with Charms: Ra. nunculus.

Yoll are the Queen of Coquettes: Queen's Rocket.

You are without Pretension: Fln. ra's Bell ; Pasque Flower; Ruse Cainpion.

You please all : Branch of Currants. You puzzle me: Love in a Mist.

Your Blush has won me: Azalea.

Your Frown I defy: Anemone.

Your Image is engraven on my Heart: spindle.Tree.

Your lonks frecze me: Ice-Plant.

Your Presence revives me: Rose. mary.

Your Presence softens my pain: Milk-Vetch.

Your qualities surpass your charms : Mignionette.

You shall have Justice: Sweet scented Tussilage.

Youth: White Lilac.

Youthful Charms: Rosebud.

You wall cause my Death: Hem lock.

Z.

Znalonsness : Filder.

Iest: Lemon. 


\section{EXPLA A TION OF THE PLA TES.}

\section{Rose.-Ivy. - Myrtle.-Frontispiece.}

To Beauty, Friendship, and Love.

II. Jasmine.-Strawberry. - Tulip.-PAGE 51.

Your amiability, and the excellence of your character, have compelled me to declare my love.

III. Primrose. - Honeysuckle. - Marygold. - PAGE 65.

Be not too early entangled in the chains or love, or yours will be a life of inquietude.

IV. Forget-me-not.-Cypress.-Pimpernel.-PAGE 93.

Forget me not, for, alas! we may never meet again.

V. Scarlet Geranium. - Scarlet Iponca.-Laurustinus.-PAGE 111. In preference, I attach myself to you, but shall die if neglected.

VI. Balsam. - White Daisy. - PAGE 121.

Be not impatient, I will think of it.

VII. Myrtle.-Sweetbrier.-Lucern.-PAGE 145.

Love is the poetry of life.

VIII. Purple and Yellow Iris. - Hawthorn.-PAGE 157.

I send you a message of love on the wings of hope.

IX. Blue Violet.-Daisy.-Apple-Blossom.-PAGE 181.

Your modesty and innocence secure you the preference.

X. Crown Imperial and Turlk's Cap Lilies. - Lily of the Valley.PAGE 197.

You have the power to restore me to happiness.

XI. Pansies. - Broom.-PAGE 213.

My heart would be at ease, if my solitude were blest with your society.

XII. Mignionette.-Heliotrope.-Pink. - PAGE 237.

Your qualities surpass your charms; I love you with a pure and de. voted love. 


\section{N D E X.}

\begin{tabular}{|c|c|}
\hline AESENCE the greatest of Evils ..... 27 & (3) \\
\hline Acanthus .................... 28 & Blue-Bottle Centaury ............ \\
\hline Acacia Rose ................... 71 & Blue Canterbury-Bell .......... 46 \\
\hline Acacia ...................... 17\% & Box......................... 217 \\
\hline A Garland of Roses .............. 198 & Bramble ..................... 76 \\
\hline Agrimony .................... 224 & Broken Straw ................ 60 \\
\hline Agnus Castus ................ 42 & Broom ..................... 166 \\
\hline Almond-Tree................ 126 & Buckbean .................. 87 \\
\hline Almond-Laurel ............... 174 & Burgundy, Duke of ........... 149 \\
\hline Amaranth ................... 122 & Buttercups ................. 128 \\
\hline Aloe $\ldots \ldots \ldots \ldots \ldots \ldots \ldots \ldots \ldots \ldots \ldots \ldots$ & Butterfly-Weed ............... 140 \\
\hline American Cowslip ............... 242 & \\
\hline Amaryllis ..................... 104 & Campanula, or Pyramidal Bellflower 224 \\
\hline Amaranth, Knights of the ........ 122 & Candy-Tuft ................ 124 \\
\hline Anemone ..................... 243 & Canterbury-Bell, Blue ......... 46 \\
\hline Anemone, כarden .............. 95 & Carnation, Yeilow ............ 59 \\
\hline Angelica ..................... 135 & Centaury, Blue-Bottle .......... 50 \\
\hline Antiquity of Language of Flora .... 20 & Charles the Simple, Anecdote of .... 60 \\
\hline Apple-Bloss.om ................ 180 & Chestnut-Tree ................ \\
\hline A Roseleaf .................... 119 & China-Aster ................. 230 \\
\hline Ash ....................... 103 & China-Rose .................. 40 \\
\hline Asphodel ...................... 165 & Cinquefoil $\ldots \ldots \ldots \ldots \ldots \ldots \ldots$. 170 \\
\hline A Tuft of Moss ................. 152 & Circæa, or Enchanter's Nightshade \\
\hline Azalea ..................... 235 & Columbine .................. 91 \\
\hline Balm of Gilead $\ldots \ldots \ldots \ldots \ldots \ldots$. & $\begin{array}{l}\text { Common Stramonium } \ldots \ldots \ldots \ldots \ldots \\
\text { Corinthian Column, Origin of ...... }\end{array}$ \\
\hline Bulsam ...................... 123 & Corn ..................... 199 \\
\hline B.urberry ..................... 209 & Cornelian Cherry-Tree ......... 63 \\
\hline Bee-Ophrys, or Orchis ........... 77 & Crocus ................... 212 \\
\hline Bulberry ................... 226 & Crown Imperial ... \\
\hline Bittersweet-Nightshade .......... 227 & 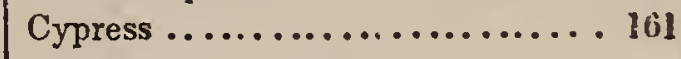 \\
\hline
\end{tabular}




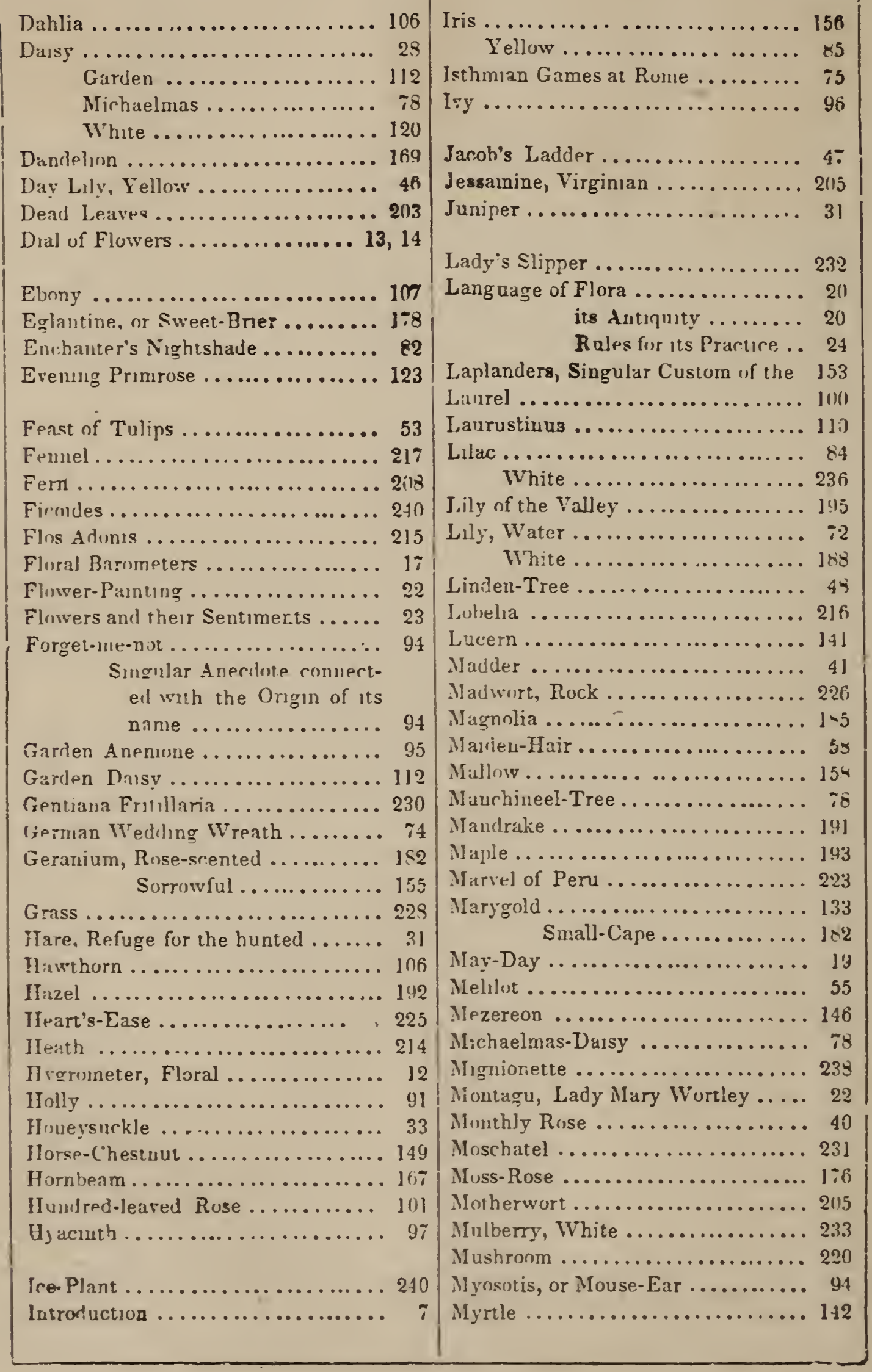


Muss, A Tuft of

My rile, Wax

Narcissus, Poet's

Night-1)lowing Cereus

N:ghtmigale, Its A ffection for the Rose 3 ?

Nightshade, Eıchauters'........ 82

Nightshude, Bittersweet ......... 22

Nymphita Lutus . . . . . . . . . . . 72

Ulive ....................171

()range-Fluwer .............. 41

Orunge-T'lee ................ 99

Pansy ...................... 225

Parsley .................. 75

Perrwinkle .................219

Peruviuu Heliotroye ............ 115

Pheasint's Eve ................ 215

Phyllis and Demophuon .......... 12i

Pimpernel.................. 30

Prue-Apple ................. 211

P.uk ..................... 148

l'nn-Tree ................. 139

$\mathbf{P}$ et's $\mathrm{Na}$ cissus ............. 69

Pupes Villuw ............... 155

Poplar, White ............... 22 ?

Pulvy .................... 41

White............... 210

Primruse ................. 66

Evenung ........... 123

Privet.................... 184

Prutectiun, Emblen of .......... 31

Rreds .................... 163

Ro:nulus, A l'resage of lis future Greutness ....................

Ruse .................... 33

Fabulisus Arcount of its Birth $3 i$

Ar:il:1:2............... $\because 1$

Hundred-leaved ........... 101

Mouthly ................. 40

Moss .................. 1;6

White ................. 206

Wiliuw or Dog ........... 20.

Jelluw ................ 125

Rnsebud ................... 233

White............. 222
Roseleaf ................... 119

Ruses, A Garland of ............. 198

Ruselsuy .................... $5 i$

Ruse-scented Gerautum .......... 182

Sardony .................... 135

S(:arlet Ipomira, or Indian Jusmine 149

Sentument of Fluwers .......... 23

Service-Tree ................ 185

Shepherd's Weathergliss ........ 30

Sidesadule-Fluwer ............. 231

Small-Cupe Maryguld ........... 182

Silapuragun ................ 24]

Srowdrop .................. 43

Sorruwful Geranium ............ 155

Spuder-Ophrys ............... 210

Spindle-Tree ................ 235

Star of Bethlehem ............ 89

Strawherry ................. 172

Stramomum, Common .......... 61

Sunflower .................. 210

Sweet Sultan ............... 83

Sweel-sceuted Tussiluge or Colisfout 133

The Fluwer-Play ............ 137

The Ruse in Ire .............. 39

The Suntherner to a Yankee ...... 186

Thurn-Apple ................ 55

Thrift................... 221

Tremella Nustoc . . . . . . . . . . . . 194

Tulp ................... 52

Tulips, Feast of ............. 53

Tulipunıana ............... 54

Venus's Car.................. 88

Venus's Flvtrap ............... 104

Venus's Luoking-Glass .......... 86

Vervain .................... 73

Virgiman Jessamme ........... 205

Vile ...................... 118

Violet, Blue ................ 159

Walking-Leaf ............... 108

Wall-Fluwer ................ 79

Watef-Lily ................ $\tau_{2}$

Water-Star ................ 32

Wax-Myrtle ................ 115

Weathergliss, the Shepherd's ..... 30

Weeping-Willow ............. 154 
White Daisy .................. 120

White Lilac ................... 236

White Lily . . .................. 188

White Mulberry ............... 233

White Poplar .................. 222

White Poppy ..................210

White Rose .................. 206

White Rosebud ................ 222

Wild or Dog Rose ............. 207

Nillow Herb................. 183
Wood Sorrel ................... 136

Woodbine ................... 33

Wormwood .................. 27

Yellow Day Jily ............... 46

Yellow Carnation .............. 59

Yellow Iris ................. 85

Yellow Rose................. 125

Zeb, Doctor.................. 119 


$\frac{m e}{R}$ 
is

$2 x+y=2$

1.

9

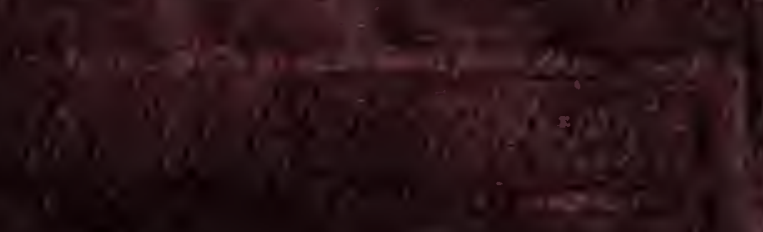

$-5$

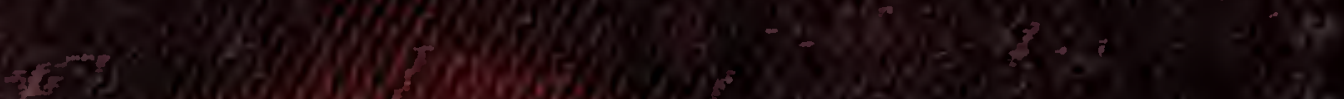

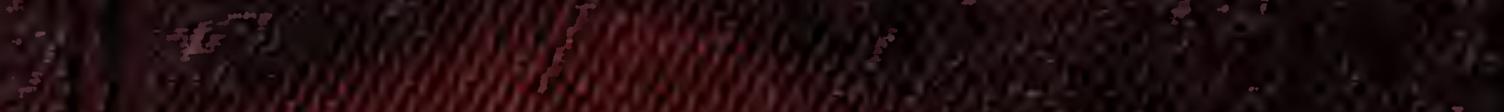

2.5.

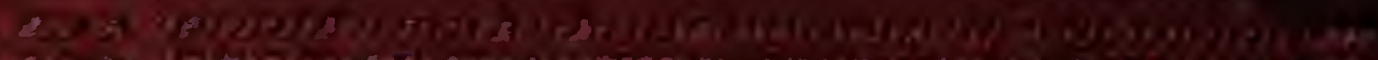

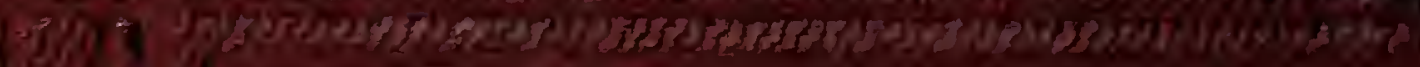

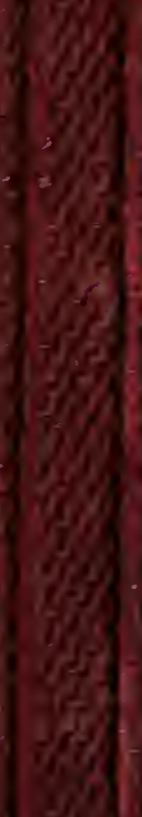
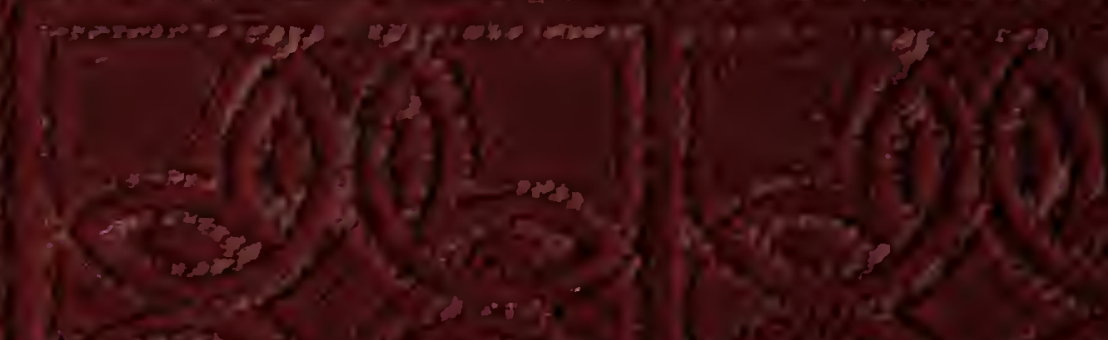

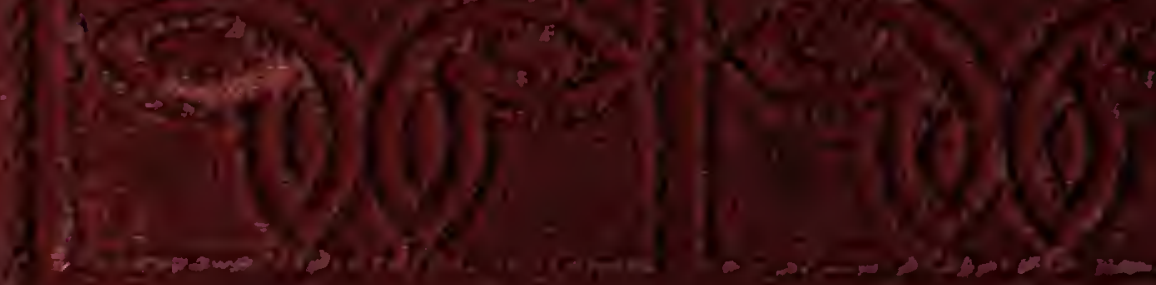

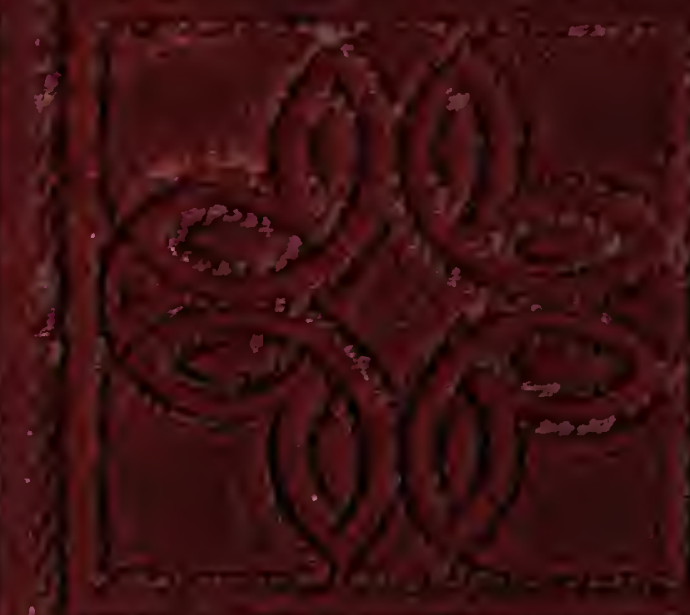

d.8.

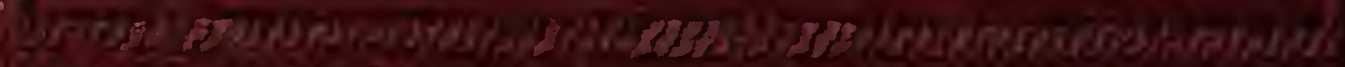

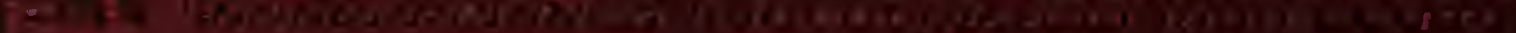

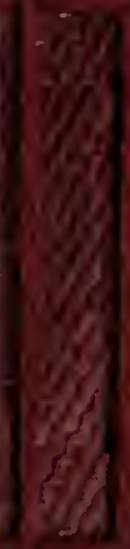

1)

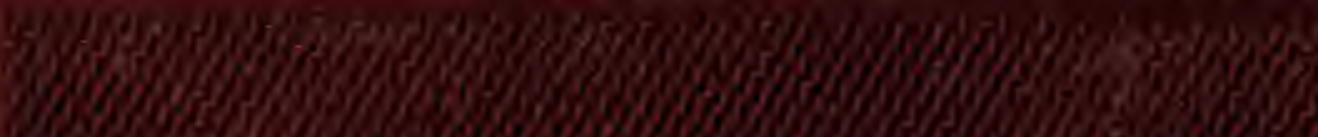

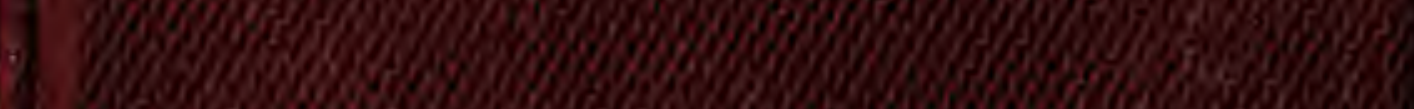

812.

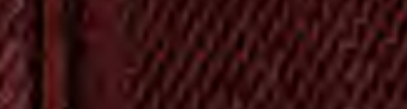

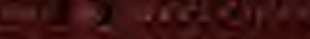

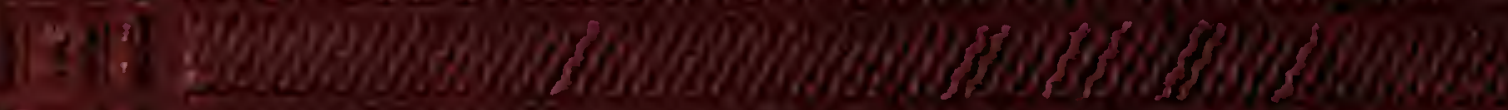

